NBER WORKING PAPER SERIES

\title{
THE MORTGAGE PIGGY BANK: BUILDING WEALTH THROUGH AMORTIZATION
}

\author{
Asaf Bernstein \\ Peter Koudijs \\ Working Paper 28574 \\ http://www.nber.org/papers/w28574 \\ NATIONAL BUREAU OF ECONOMIC RESEARCH \\ 1050 Massachusetts Avenue \\ Cambridge, MA 02138 \\ March 2021, Revised October 2021
}

We would like to thank seminar participants at AREUEA Virtual Seminar, Baruch College, CFDM Lab Group, CU Boulder finance lunch, FDIC Consumer Research Symposium, New Perspectives on Consumer Behavior in Credit and Payments Markets, CFPB Research Conference, European Finance Association. Finance in the Cloud Conference, MIT Sloan Junior Finance Conference, Northern Finance Association, Philadelphia FED, SITE, NBER SI Corporate Finance 2020, Western Finance Association Annual Meeting, and Stanford GSB Finance. We would also like to thank our discussants Anthony DeFusco and John Beshears, as well as Adrien Auclert, Claes Backman, Bo Becker, Matteo Benetton, John Campbell, Taha Choukhmane, Tony Cookson, Daniel Fernandes, Virginia Gianinazzi, Paul Goldsmith-Pinkham, Andrew Hertzberg, John Lynch, Marco Di Maggio, Anastassia Fedyk, Nicolae Garleanu, Amir Kermani, Benjamin Keys, Laura Kodres, Arvind Krishnamurthy, Deborah Lucas, Gustavo Manso, Patrick Moran, Jordan Nickerson, Terrance Odean, Michaela Pagel, Christopher Palmer, Jonathan Parker, Daniel Paravisini, Giorgia Piacentino, Kasper Roszbach, Antoinette Schoar, David Schoenherr, Felipe Severino, Amir Sufi, David Sraer, Daan Struyven, Jialan Wang, Emil Verner, James Vickery and Luana Zaccaria for helpful comments. Previous versions of this paper circulated under the title "Mortgage Amortization and Wealth Accumulation." The views expressed herein are those of the authors and do not necessarily reflect the views of the National Bureau of Economic Research.

NBER working papers are circulated for discussion and comment purposes. They have not been peer-reviewed or been subject to the review by the NBER Board of Directors that accompanies official NBER publications.

(C) 2021 by Asaf Bernstein and Peter Koudijs. All rights reserved. Short sections of text, not to exceed two paragraphs, may be quoted without explicit permission provided that full credit, including $(\odot$ notice, is given to the source. 
The Mortgage Piggy Bank: Building Wealth through Amortization

Asaf Bernstein and Peter Koudijs

NBER Working Paper No. 28574

March 2021, Revised October 2021

JEL No. D14,D15,E21,E6,G21,G4,G5,G51,J2,R3

\begin{abstract}
$\underline{\text { ABSTRACT }}$
Mortgage amortization schedules are among the largest savings plans in the world (ex. U.S. households contribute hundreds of billions of dollars annually to these "mortgage piggy banks"). However, little is known about their effects on wealth accumulation. Ex-ante, the effect is unclear. It depends on the fungibility of home equity and other savings, and households' willingness to adjust consumption or leisure. Empirically, effects are difficult to identify since amortization and other savings choices are typically co-determined. We overcome this challenge by utilizing a 2013 Dutch reform that increased amortization requirements for new mortgages. Using detailed administrative data, we compare savings decisions for home-buyers right before or after the reform. We use plausibly exogenous variation in the timing of home purchase coming from life-events (ex. birth of a child) to address selection concerns. We find that marginal wealthbuilding from amortization (MWA) is substantial. Remarkably, households leave non-mortgage savings untouched and cut consumption and leisure instead, implying a near 1-for-1 rise in networth. Results hold five years out when the additional amortization-induced home equity is larger than the stock of liquid savings, suggesting substantial amounts of amortization-driven wealthbuilding over a typical business cycle. Effects are ubiquitous and hold for unconstrained households, who could easily offset the additional amortization by reducing non-mortgage savings, and movers, suggesting a broad applicability of our results. Overall, our results highlight the critical importance of mortgage amortization for household wealth-building and macroprudential policies.
\end{abstract}

\author{
Asaf Bernstein \\ Leeds School of Business \\ University of Colorado at Boulder \\ Campus Box 401 \\ Boulder, CO 80309 \\ and NBER \\ asaf.bernstein@colorado.edu \\ Peter Koudijs \\ Erasmus School Economics-Business Economics \\ University of Rotterdam \\ Postbus 1738 \\ 3000 DR Rotterdam \\ Netherlands \\ koudijs@ese.eur.nl
}


Mortgage amortization schedules are recurring debt repayment plans that promote building savings in the form of home equity over time - akin to a "mortgage piggy bank". Amortization amounts are substantial at both the household and macroeconomic level. For example, U.S. households contribute hundreds of billions of dollars to these plans annually. This is of the same magnitude as pension contributions, the other major form of illiquid savings. ${ }^{1}$ Despite the importance of mortgage amortization, we know surprisingly little about its effect on wealth building. Theoretically, effects are uncertain. In standard models, households would be expected to partially undo amortization via home equity withdrawals or by saving less in other accounts. Empirically, our knowledge is limited. This is likely driven by identification challenges: the decision about how much to save and the choice to purchase a house with a particular mortgage contract are jointly determined.

In this paper, we overcome these challenges by combining a plausibly exogenous increase in mortgage amortization for Dutch home-buyers around a macroprudential mortgage reform in 2013 with detailed administrative data on household savings. We then provide the first causal evidence of estimates of the Marginal Wealth-building from Amortization (MWA), a key parameter that has critical economic and policy implications. Comparing buyers around the reform, we find that the average MWA is close to one (0.9-1.0). Each dollar of additional amortization leads to nearly one dollar of additional wealth building. This is accomplished by cutting expenditures (around 2/3), and increasing labor supply (around 1/3). There is little evidence that households cut other forms of savings. We obtain similar estimates for households who save regularly, build-up extra home equity, and contribute to their pensions on top of the standard employer-sponsored programs. This shows that our findings are not driven by households who are at a corner solution that do not want to build wealth. Further, we find no evidence that households undo the additional amortization when given the opportunity during a move, even when doing so would be relatively cheap and easy. Moreover, our results continue to hold five years later (when our data ends). At that point, the additional amortization-induced wealth accumulation exceeds the average household's stock of liquid assets. This suggests that the impact on wealth accumulation is likely to be persistent and substantial.

The key advantage of studying the Dutch mortgage reform of 2013 is that the institutional setting and availability of detailed data allow us to overcome a number of identification challenges. Prior to the reform, first-time home buyers (FTHBs) typically borrowed half of the mortgage sum interest-only. Afterwards, the vast majority borrowed the full amount through a standard fully amortizing mortgage. This caused a substantial rise in required monthly debt repayments. Typical homeowners were “compliers” both

\footnotetext{
${ }^{1}$ In 2016, there were $\$ 10.3$ trillion in U.S. residential mortgages (FRED) with $2.5 \%$ of principal scheduled to be amortized and 2.8\% actually repaid in 2016 (CoreLogic), equating to \$250-300 billion in savings via mortgage amortization. By comparison, there were around $\$ 398$ billion in 401(k) pension contributions reported to the Department of Labor in 2016 (including both employee and employer contributions).
} 
before and after the reform. As such, our results apply to the broader population, rather than a particular subset. We look at all FTHBs who bought around the end of 2012 and beginning of 2013 and compare their wealth accumulation over the same later years (2014-2017). Differences in wealth accumulation are smooth and flat as a function of mortgage age before the reform, then jump up suddenly and persistently the month the reform took effect. This indicates that results are not driven by differences in mortgage age. Moreover, the reform did not lead to any changes in the supply side of the Dutch mortgage market and was not accompanied by other major policy changes that might alter wealth accumulation. This suggests that our results are unlikely to be confounded by concurrent events. ${ }^{2}$

Another advantage from studying the Dutch 2013 reform is that it did not change how payment-toincome (PTI) requirements were computed. Already before the reform, these were computed as if the loan was fully amortizing over 30 years, even if it was 50\% interest-only. As such, the reform did not change the maximum mortgage households could get based on their income. As a result, we find no evidence that the reform affected the timing of home purchase (i.e. there is no bunching). Furthermore, there are no systematic differences in the observable characteristics of households purchasing a home before or after the reform such as pre-reform savings, income, income growth, or initial interest rate, house value, or LTV. There are also no differences in future income growth, except for the fact that households buying after the reform choose to work more hours to (partially) pay for the increased amortization. This suggests that the selection of households into homeownership did not change after the reform.

We consider two remaining concerns regarding selection on unobservables. First, there could be changes on the extensive margin. Certain households, who would have bought earlier, may have dropped out after the reform. This could be demand- or supply-driven. In particular, households with higher expected income growth may have been relatively more willing to purchase a new home after the reform, and more likely to be approved for the mortgage. This is unlikely to be the case in our setting: (i) If post-reform buyers had different income growth profiles, we would expect non-mortgage savings or debt repayment to be different. In reality, they are nearly identical. (ii) Buyers do not purchase smaller houses, indicating that there is no adjustment on the intensive margin, making adjustment on the extensive margin unlikely. The lack of bunching also suggests that households did not rush to purchase a home before the reform. (iii) It is unlikely that mortgage supply changed. Similar to many other countries, lenders typically do not consider

\footnotetext{
${ }^{2}$ We also show that it is unlikely that our estimates are driven by concurrent treatment from the reform itself. Findings are similar in early and later years after treatment, suggesting liquidity effects were small. Findings are also similar when using within-household variation in amortization over the life of the contract, suggesting that effects are not driven by a one-time (perceived) shock to wealth. Further, when looking at non-FTHBs, effects are similar across households with different remaining maturities of their mortgage during which they were grandfathered under the old rules, confirming that any (potential) wealth shock from the reform did not materially affect behavior.
} 
expected future income growth and this did not change after the reform. ${ }^{3}$ Proxies for differential screening, such as initial interest rates and LTVs, also do not change after the reform. (iv) We see no evidence of prereform differential income growth nor changes in future income coming from anything other than the hours they choose to work. We show that the MWA is also close to 1 for households that cannot increase the number of hours worked because everyone aged 21 and older already works full-time. (v) There is no decline in the likelihood of purchasing a home. In particular, we consider FTHBs who also had a "lifeevent” in the months around the reform. The high-quality administrative data in the Netherlands lets us identify the exact month when there are changes in the number of members of the household, such as the birth of a child. We document that the timing of a life-event strongly predicts whether households purchase before or after the reform, but is uncorrelated with observable pre-reform household characteristics. We show that the propensity to own a house four years after the reform is the same for those who experience a life-event (just) before or after the reform.

Second, households may have selectively timed their home purchase around the reform. If this is systematically correlated with later savings decisions, this could bias our results (ex. those who buy earlier intend to save less). The previous results indicate that life-events change the timing, but not the likelihood, of home purchase. To address concerns about selective timing, we can therefore use life-events as an instrumental variable for the timing of home purchase around the reform. Results confirm that increases in mortgage debt repayments are matched nearly one-for-one with changes in wealth accumulation. As with our baseline estimates, this change is sudden and persistent, suggesting that these cohorts are not on different points in their life-cycle. Further, it is implausible that the timing of life-events within this period is driven by the reform.

A potential disadvantage from using the 2013 Dutch mortgage reform is that our results might be specific to the Dutch institutional setting. In response, we present evidence that patterns are likely to be more generally applicable. First, unlike some other northern-European countries, it is unlikely that the median Dutch household is at a corner-solution and has no interest in additional wealth accumulation. Starting in 1990s, the Dutch government has restricted the amounts Dutch households can save in taxexempt pension accounts (with recent restrictions in 2011 and 2015). They have done so exactly because most households were contributing at the limit, and this hurt short-term tax revenues. ${ }^{4}$ That Dutch households are willing to save is also supported by prior research that shows that households decide to save

\footnotetext{
3 “The mortgage lender will, when determining the borrowing capacity of a mortgage applicant, consider their current fixed and permanent income. (...) (italics added for emphasis)." Gedragdscode Hypothecaire Financieringen (Code of Conduct for Mortgage Loans), 2011, article 6.3. For self-employed individuals, the borrowing capacity was based on the average income over the last three years. Rules remained the same around the reform; see Tijdelijke Regeling Hypothecair Krediet (Temporary Regulation Mortgage Credit), 2012, article 2.

${ }^{4}$ Wet verlaging maximumopbouw- en premiepercentages pensioen en maximering pensioengevend inkomen (33.610); Memorie van toelichting (TK, 3), April 15, 2013.
} 
a large part of an exogenous shock to their wealth (Kuhn et al. 2011). Second, it is unlikely that results are driven by the Netherlands having a high marginal tax rate. If anything, home-buyers pay higher taxes if they bought after the reform and are therefore less (and not more) likely to increase savings. Third, our estimates for the MWA are ubiquitously high among the broad range of sub-groups we examine. These include older households, non-FTHBs, households who voluntarily pay-in substantial amounts of home equity at origination (LTVs below the regulatory cap), and households who have and accumulate substantial wealth in the form of other savings. Finally, our effects are in line with aggregate statistics comparing the U.S. and the Netherlands that show that households appear to follow amortization schemes in building home equity over the life cycle.

Our results suggest that amortization is a first-order driver of aggregate household wealth-building. For example, holding all else constant, a simple linear aggregation of our partial equilibrium estimates would imply that in the absence of mortgage amortization, U.S. homeowners would save \$1.25-1.5 trillion less over the next five years. Even though the long-run effects of the 2013 Dutch reform are as of yet uncertain, our results do indicate that the effects over a typical business cycle are substantial. ${ }^{5}$ Our findings therefore highlight the importance of amortizing mortgages as a channel through which homeownership can contribute to wealth-inequality, since unequal access to housing implies unequal access to amortizationinduced savings. ${ }^{6}$ They also point to the importance of standardized mortgage maturities which differ widely across countries. ${ }^{7}$ Further, our results have important policy implications. They suggest that freezing mortgage amortization and/or payment moratoria, as many countries have done in response to Covid-19, are an even more effective way to stimulate consumption than might be implied by standard models. Doing this in the U.S. for a period of two years would be similar to the dollar amount of all TARP (Trouble Asset Relief Program) payments in the four years following the Great Recession. Finally, our results stand in contrast to classic models of consumer behavior, since households appear to treat amortization-driven home equity as completely infungible with their other forms of wealth, and so do not alter savings plans in response to changes in amortization.

\section{Related Literature}

Our work's main contribution is to the literature on optimal mortgage design. First, our results speak to the costs and benefits of interest-only (IO) mortgages or alternative mortgage products (Mian and Sufi 2009;

\footnotetext{
${ }^{5}$ Over the past half-century, the average NBER dated business cycle was around 5 years.

${ }^{6}$ For example, over the last half-century, black households in the U.S. have been 20-30 percentage points less likely to be homeowners (U.S. census IPUMS various years).

${ }^{7}$ The average mortgage maturity over the past forty years in Sweden was 45 years, but in Germany was only 15 (hofinet.org).
} 
Adelino et al. 2016; Hertzberg et al. 2018). Ex-ante, one might expect that smaller amortization amounts would cause more non-mortgage savings, increasing households' financial buffers, which could improve financial stability (Svensson 2019; Svensson 2020). By contrast, we find no such offsetting. Second, our results speak to macroprudential policies during recessions (Piskorski and Seru 2018). For example, policies that encourage contracts with countercyclical amortization (Guren et al. 2019; Campbell et al. 2019; Kovacs and Moran 2020) are likely to have an even bigger impact than implied by standard models. Third, we find no evidence of bunching or systematic timing by different groups around the reform. This suggests that policies that increase amortization without changing regulatory leverage limits might be able to encourage wealth-building without excluding the groups intended to be treated. In contrast, Best et al. (2018), DeFusco et al. (2020), and Backman and van Santen (2020) show that when regulatory constraints on leverage bind or involve interest-rate jumps, substantial bunching and selection can occur. Fourth, our findings have implications for the causal effect of policies promoting homeownership on household wealth. Households appear to use home equity as a primary form of savings, with real estate accounting for over 70\% of U.S. households assets (Campbell 2006; Poterba et al. 2013). In most countries home purchases are financed with an amortizing mortgage. Our results suggest that this can be a key mediating factor between homeownership and wealth accumulation. ${ }^{8}$ Further, prior work documents that certain macroprudential regulations can systematically exclude certain groups based on income or race (Charles and Hurst 2002; Krivo and Kaufman 2004; Appel and Nickerson 2016; Aaronson et al. 2017; Anders 2018; Krimmel 2018; Stein and Yannelis 2020; DeFusco et al. 2020). Our result suggest that this could lead to differential wealth accumulation. Finally, our findings have implications for the optimal design of savings programs. Beshears et al. (2019) argue that, under taste shocks and present-bias, the socially optimal savings plan includes an account with early liquidation costs, much like the amortization-induced home equity that we document in this paper. We leave for future research whether building home equity can be an important component of retirement plans, or whether households' reluctance to touch home equity (even in retirement) makes it unsuitable (e.g. Venti and Wise 2004).

Our work is closely related to other papers exploring the correlation between (amortizing) mortgages, consumption, savings and labor income decisions. Prior work has investigated the consumption and labor decisions of those who choose interest-only (IO) mortgages or alternative mortgage products (Larsen et al. 2018; Backman and Khorunzhina 2020). In theory, this setting could be used to look at the effect of amortization on wealth building. However, this is unlikely to yield reliable estimates of the MWA.

\footnotetext{
${ }^{8}$ Sodini et al. (2021) examine variation in homeownership in a setting with little-to-no amortization, while we keep homeownership constant and vary the amount of amortization. These approaches are complementary and focus on two different components of typical home-ownership, which combines having both a house and an amortizing mortgage.
} 
Households choosing IO mortgages or AMPs have been shown to differ systematically and substantially even prior to home purchase, in terms of their liquidity constraints, financial sophistication, savings preferences, and future income expectations (Cocco 2013; Cox et al. 2015; Kuchler 2015). Other work has looked at mortgage run-offs (moments when mortgages are fully repaid) to provide quasi-experimental evidence on effects of the complete removal of mortgage payments on household behavior (Coulibaly and Li 2006; Scholnik 2013; Andersen et al. 2019). In theory, the same setting could be used to estimate the MWA, but selection concerns make this challenging. Just like the choice of mortgage type is potentially endogenous, so is the choice of when to finally repay a mortgage. ${ }^{9}$ Even if these challenges could be overcome, results would complement (rather than compete with) our current findings: whereas we measure the wealth effects of amortization during a household's first formative years, mortgage run-offs provide insights much later in life-cycle, arguably around a watershed moment when individuals start thinking about moving, semi-retiring, etc.

Our work connects to a large literature that identifies different mechanisms that stimulate households to accumulate wealth. Mortgage amortization shares some of the same features. First of all, our results connect to the finding that extracting home equity can be costly (e.g. DeFusco and Mondragon 2019) so amortization may act as a commitment device (Laibson 2015; Beshears et al. 2015; Kovacs et al. 2020; Kovacs and Moran 2020, Attanasio et al. 2020; and Vihriala 2021). Second, the Dutch mortgage reform changed the "default” mortgage contract and home equity accumulation plan. In others contexts, default settings have been shown to nudge people into saving more (Madrian and Shea 2001; Thaler and Sunstein 2009; Chetty et al. 2014; Kuchler and Pagel 2019; Beshears et al. 2019), especially if this happens through small recurring payments (Beshears et al. 2013; Hershfield et al. 2019). Third, our results connect to evidence suggesting that households consider home equity as a different form of wealth than regular savings (Camanho and Fernandes 2018; Argyle et al. 2019). Finally, our findings connect to evidence that households have a "perceived precautionary savings motive" whereby they overestimate their need for liquidity (Olafsson and Pagel 2017; Aydin 2019; D’Acunto et al. 2020). This might lead to a heuristic (ruleof-thumb) savings rule that treats amortization plans differently than other forms of savings. ${ }^{10}$ Mortgage

\footnotetext{
${ }^{9}$ Run-offs only provide a quasi-exogenous change in amortization if they were determined (far) in the past, in particular if borrowers chose to remain on the same amortization schedule during the life of mortgage, without prepaying or refinancing. However, such borrowers are rare and likely unrepresentative. By revealed preferences, they take their amortization schedule as given and adjust consumption and other savings around it. Their response to a mortgage run-off is likely to be different from those who did choose to pre-pay or refinance. Alternatively, one could look at the anticipated run-off based on the "glide-path" of a household's mortgage repayment. However, that timing is a choice, potentially reflecting pre-payments that are jointly determined with future consumption, savings, and labor income decisions. For example, households may time the run-off to coincide with the desired moment to work fewer hours (in anticipation of retirement) or anticipated changes in spending patterns and savings goals.

${ }^{10}$ For example, the Dutch National Institute for Budget Information (NIBUD) offered an online tool to advise people on their optimal savings (www.nibud.nl/beroepsmatig/vernieuwde-bufferberekenaar). This makes no allowances for wealth accumulation through amortization. This is consistent with advice given in other countries.
} 
amortization combines these features, but different elements can interact in ways not seen in other contexts. For example, in the context of pension contributions, it is relatively inexpensive to undo default settings (this might explain why households undo some "default-induced" contributions down the road Choukhmane 2019, Wang et al. 2020). In the context of mortgage amortization though, this is much harder to do given the high costs associated with extracting home equity. Such unique features suggest that the “mortgage piggy bank" should be considered a distinct mechanism that causes people to save more.

Our work also relates to a large literature estimating the marginal propensity to consume (MPC) or save (MPS) out of wealth shocks, though only indirectly. The MPS and MWA estimate distinct economic primitives: the MPS measures how much of an exogenous shock to wealth is retained; by contrast, the MWA indicates how much households choose to save when encouraged to build-up more wealth through an amortization plan. An MPS of 1 requires no action on the part of the household since the additional wealth is just exogenously given, while an MWA of 1 requires a household to cut consumption and/or increase income to build wealth. Nevertheless, comparing our estimate against that of the MPS in the literature provides a number of valuable insights. First, there is work looking at the effects of mortgage interest rate resets (Di Maggio et al. 2017; Zator 2019). This work shows a surprisingly similar response: households treat interest and amortization payments as remarkably similar, even though they are fundamentally different (i.e. one is an expense, while the other a form of savings). Second, there is a large literature looking at the effects of housing wealth changes. Increases in net-wealth are often largely retained rather than consumed. ${ }^{11}$ Though generated by an entirely different mechanism, this is in line with our finding that households do not consider home equity a form of wealth that they are willing to consume, at least not in the short run. ${ }^{12}$

Finally, our paper is part of a fast-growing literature using detailed administrative household data from Northern European countries to provide empirical estimates of parameters of broader economic interest (e.g. Kuhn et al. 2011; Cloyne et al. 2019; Best et al. 2020; Andersen et al. 2020; Sodini et al. 2021).

\footnotetext{
${ }^{11}$ Most relevant to our work are contributions looking at partial equilibrium housing wealth/equity shocks (Engelhardt 1996; Disney et al. 2010b; Cooper 2013; Leth-Petersen 2010; Cloyne et al. 2019; Bernstein 2020; Ganong and Noel 2020). There is an even broader literature looking at regional changes in house prices (e.g. Mian et al. 2013; Farrell et al. 2020; Guren et al. 2020). While these may be less apt comparisons if they include some local general equilibrium effects, results are broadly consistent with the vast majority of housing wealth increases being saved rather than consumed.

${ }^{12}$ What happens in the longer run is outside the scope of this paper (and, to the best of our knowledge, is also not addressed by the MPS literature). There is suggestive evidence that households retain home equity later in the lifecycle. Kaplan et al. (2014) document the existence of a large group of older households with substantial home equity but little-to-no other forms of wealth ("wealthy hand-to-mouth"). There is an older literature showing that households later in life, and even in retirement, do not consume their home equity (Feinstein and McFadden 1989; Venti and Wise 1989, 1990, 2002, 2004; Thaler 1990; Skinner 1994, 1996). These patterns are consistent with households deferring the consumption of their home equity to future generations, but they could also reflect long-run preferences for home equity that crowd-out other forms of savings.
} 
For example, Kuhn et al. (2011) examine how households in the Netherlands adjust their consumption and labor in response to winning a (zip-code level) lottery. They find that responses are broadly in-line with those found in other countries and settings (e.g. Johnson et al. 2006; Agarwal et al. 2007; Parker et al. 2013; Keung 2018; Cookson et al. 2019; Jørring 2020; Ganong and Noel 2020). While any parameter estimated in only one country is subject to that country's institutional and cultural setting, prior work has demonstrated that household consumption, saving, and labor responses in the Netherlands can provide important more general insights.

\section{Mortgage Environment in the Netherlands}

\subsection{Pre-Reform}

Assisted by strong recourse laws ${ }^{13}$, and stimulated by generous mortgage interest deductibility policies, the Netherlands has had traditionally loose origination practices for mortgages. This facilitated large interestonly (IO) components and loan-to-value (LTV) ratios well in excess of 100\%. Starting in 2001, the Dutch government began to place limits on these practices. In order to be eligible for mortgage interest deductibility and the national mortgage insurance ${ }^{14}$, the mortgage maturity was limited to 30 years and the IO part was capped at $75 \%$ of the mortgage sum. In an effort to keep tax benefits on the amortizing part, banks introduced linked savings accounts. This contract is virtually identical to a standard amortizing mortgage, but with larger tax benefits. Homeowners deposit a monthly sum equal to a regular amortization amount into a savings account that has the same interest rate as the mortgage. The accumulated savings are used to fully repay the mortgage at maturity, while the interest payments on the linked savings cover (part of) the mortgage interest payments. Homeowners are not allowed to access the savings during the duration of the mortgage. Returns on savings are not taxed.

In 2007, banks signed a Code of Conduct for Mortgage Loans (CCM) that further tightened mortgage rules. Initially it set limits on payment-to-income (PTI) and LTV ratios. In August 2011, it set the maximum IO component of new mortgages to $50 \%$. The other half could be in the form of a mortgage with a linked savings account, as long as it amortized over a period of 30 years (or less). Following this reform, the vast majority of mortgages originated had 50\% IO and 50\% linked accounts. In addition, the revised CCM set the maximum origination LTV at $106 \%$, with $1 \%$ reductions each year afterwards until it finally

\footnotetext{
${ }^{13}$ According to Moody's, recourse laws in the Netherlands are "very strong", also in terms of enforcement, while it is "weak" in the U.S. (NVB 2014). During the Great Recessions, foreclosure rates in the U.S. were almost a hundred times higher at their peak than in the Netherlands, even though a higher proportion of households had negative equity in the Netherlands.

${ }^{14}$ The insurance was only available if the house value was less than a maximum amount (€320 $\mathrm{k}$ in 2012), and if the payment-to-income ratio was below a certain limit. The insurance provided additional protection and liquidity from originating banks, resulting in a pass-through effect of substantially lower interest rates for borrowers.
} 
reached $100 \%$ in January of $2018 .{ }^{15}$ Similar to the uptake of IO mortgages, households tended to borrow up to the allowable regulatory limits. For first-time home buyers (FTHBs) in 2013, more than $40 \%$ of mortgage offers were within 5 percentage points of the regulatory LTV limit and around 20\% of all mortgage offers were at exactly the limit.

\subsection{The 2013 Reform}

For new mortgage sums contracted after January $1^{\text {st }}$, 2013, the Dutch government implemented a new macroprudential policy intended to promote "Financial Stability”. Proposed at the end of April 2012 and passed in October of that year, the new policy required FTHBs to have fully amortizing 30-year mortgages in order to be eligible for mortgage interest deductibility and national mortgage insurance. ${ }^{16}$ New IO mortgages and mortgages with linked savings accounts lost their eligibility. Existing homeowners were grandfathered under the old rules for the remaining maturity on their existing mortgages, but fell under the new rules for any mortgage increases. During most of 2012, it remained uncertain whether the policy would pass and if so in what form. In an article published on August 31 $1^{\text {st }}, 2012$ ABN Amro, one of the largest banks and residential mortgage lenders in the Netherlands, noted that " $[t]$ he future concerning the measures is far from certain, since it is a very hot political issue. The election results on 12 September 2012 are crucial in this respect and could change the situation drastically. ${ }^{17}$ In the end, the policy passed as proposed.

Figure 1 shows that in the beginning of 2012, less than 5\% of offers were for standard fully amortizing mortgages, while in the beginning of 2013 almost 95\% were, causing a dramatic increase in the percentage of the mortgage balance expected to be repaid. The data suggests that households undid littleto-none of the treatment of the reform via differential voluntary repayment or home equity withdrawals. We compare expected versus actual mortgage repayment over 2015 for FTHBs buying before or after the reform. Based on information provided by the Mortgage Data Network (HDN) on mortgage offers, we expect that those buying after should have repaid an additional $1.5 \%$ of the mortgage sum. This is matched almost exactly by observed mortgage repayments in Statistics Netherlands (CBS).

Examining the Dutch 2013 reform has a number of benefits. First, almost all FTHBs were compliers both before and after the reform. This implies that our estimates likely apply to the broader population, rather than a particular subset of households who endogenously choose IO mortgages (as would be the case in many settings like the U.S.). Second, while the reform clearly increased monthly amortization payments, it did not mechanically alter regulatory maximum PTI limits. Even prior to the reform, the National Institute

\footnotetext{
${ }^{15}$ See Struyven (2015) and van Bekkum et al. (2019) for more discussion of this regulatory change and its effects.

${ }^{16}$ Parliamentary document 33405-29. "Wijziging van de Wet inkomstenbelasting 2001 en enige andere wetten in verband met de herziening van de fiscale behandeling van de eigen woning (Wet herziening fiscale behandeling eigen woning)".

17 "Covered Bonds in the Netherlands”, ABN Amro (September 2012).
} 
for Budget Information (NIBUD) would compute PTI limits as if the mortgage was a standard fully amortizing 30-year fixed rate loan, regardless of the actual mortgage type or terms. Third, mortgages were already partially amortizing, and had been for some time prior to the reform. This means we can contribute effects to increases in amortization, not the introduction of amortization itself. Fourth, we do not see evidence of other dramatic changes in macroeconomic and mortgage conditions around the reform. Figures A2 and A3 shows that house prices, mortgage rates, and average origination loan-to-value and income ratios varied smoothly around the reform. Even though increased amortization implies shorter duration, average mortgage interest rates are also smooth. This likely reflects the fact that default risk is limited (because of the strict recourse laws), and that fixed rate periods are typically short (85\% of homeowners had rates that become floating within the first 10 years).

Existing homeowners wanting to buy a new home were also affected by the reform, but to a smaller degree. Mortgages outstanding on January 1, 2013 were fully grandfathered under the old rules for their remaining maturity. In practice, this means that the effect of the reform was larger for existing homeowners with mortgages with shorter remaining maturities.

\section{Data description}

\subsection{Datasets and Sample}

Our primary analysis takes advantage of administrative datasets from CBS, with individual-level financial information on every person living in the Netherlands from 2006-2017. The datasets are transactions in the existing purchase dwellings registry (Bestaande Koopwoningen), the universe of spells for individual addresses (Adresbus) and family structure (Huishoudensbus), household balance sheets (Integraal Vermogen) and the population socio-demographic characteristics (Persoontab). From the household spell registry, we obtain variables such as the household size, the type of household (ex. married without children) as well as the position of the individual in the household (ex. partner in married couple without children). These household structure variables allow us to pin down the timing of changes in family structure, such as the birth of a child, death of a family member, divorce, etc. Housing transactions are based on the month a household is registered as taking ownership of the property, which typically differs by at least 2 months from the date they went under contract. Housing data comes from the Kadaster (deeds office), social and demographic characteristics come from the Bevolkingsregister (civil register, administered by local municipalities), while household balance sheets come from the national tax records and the national credit registry.

We focus our analysis on all 111,523 people in the Netherlands who bought their first home financed with any kind of mortgage in either 2012 or 2013 and examine their outcomes in the years around the house purchase. Table 1 Panel A provides simple summary statistics on these households. The strict 
recourse laws (and their enforcement) in the Netherlands are associated with high initial LTV ratios, usually well in excess of $100 \%$. With a median of about $105 \%$, this is true for the buyers in our sample as well. In line with the overall population of homeowners, mortgage liabilities are by far the largest component of average household debt. For our group the median mortgage balance is $€ 187 \mathrm{k}$, with median total debt at $€ 193 \mathrm{k}$. As first-time home buyers, households in our sample tend to be fairly young, with a median age of 36 years for the oldest household member, and have a fairly high income, which is why they are able to buy a house, with a median household gross income in 2014 of about $€ 54 \mathrm{k}$.

\subsection{Liquid Assets}

Consistent with their relatively high income, the median household in our sample has a non-negligible amount of liquid assets. This has substantial variability. We measure liquid assets as the combination of all deposits (money in all checking and savings accounts) and financial instruments like stocks and bonds. The Netherlands has a wealth tax and information on liquid assets is collected comprehensively at the household level and verified by financial institutions. Table 1 Panel A shows that the median household has close to $€ 8 \mathrm{k}$ in liquid assets, with the $25^{\text {th }}$ percentile at $€ 2.6 \mathrm{k}$.

Since incremental amortization-induced wealth accumulation will end up at around $€ 2 \mathrm{k}$ the majority of these homebuyers will have sufficient stocks of liquid savings, they could, in theory, choose to run them down in order to avoid re-levering or cutting consumption/leisure. That said, for the lower end of that distribution some of those reductions could be quite substantial, so we also run analysis focusing on households with more substantial savings. We consider a number of ways to look at less constrained households in our regressions which we discuss more later, but one group we consider is those who have at least $€ 10,000$ as of the end of 2015 or accumulate at least $€ 3,000$ in additional liquid assets over 2015. As shown in Table 1 Panel B this group has mean(median) liquid assets of around $€ 35 \mathrm{k}(€ 24 \mathrm{k})$, making the amortization-induced additional wealth accumulation a fairly small portion of their overall liquid wealth. This group also on average (mean and median) accumulates an additional €3k in liquid assets in a given year, which means they could offset amortization-induced wealth accumulation just with future savings, and without cutting into their current stock of savings at all. Not only are these groups able to access wealth or savings plans they could just to offset amortization, they also appear to be regularly accumulating wealth, suggesting these are unlikely to be households with no interest in building wealth. We focus the majority of our analysis on these first-time home buyers since they are not affected by any partial grandfathering discussed previously but obtain similar results looking at all buyers, including those who have owned homes previously (i.e. repeat buyers), who are shown in Table 1 Panel C. They also have substantial liquid assets they could use to offset amortization, as well as having more experience with understanding mortgages and homeownership. In our analysis we will explore how the MWA varies among these, as well as other sub- 
groups, including those below mandatory regulatory leverage limits, those who have stocks of prior liquid assets they haven't spent down yet, those with financial securities (i.e. stocks or bonds), and across a broad range of ages of the household head.

These findings do not reflect a staleness in the administrative data on savings nor a lack of propensity to ever vary wealth among households in our data. The within household year-over-year standard deviation in liquid assets is about €14k between 2006 and 2017 (not reported). In 2014 this was about €9k. This variation appears to be driven by changes in economic conditions faced by households. In appendix Figure A1, we plot yearly changes in liquid assets in the years around a decline in gross household income, after including household and time fixed effects. As expected, there is a substantial reduction in the year of the income decline as households likely use their liquid assets as a buffer. This provides some validation of the administrative data collected and verified by the Dutch government, and shows that households have non-negligible stocks, flows, and variability in their liquid assets.

\subsection{Measuring Wealth Accumulation}

One of the advantages of exploring this reform in the Netherlands is the presence of detailed administrative data on wealth and its components at the household-level. In this paper we focus on wealth accumulation defined as the year-over-year change in a household's assets minus their liabilities.

For our primary analysis we include all assets reported by CBS that represent wealth accumulation decisions of the household. We consider the change in all liquid assets, as discussed in Section 3.2, as well as implied voluntary pension contributions, which together we refer to as financial assets. ${ }^{18}$ Since we do not observe the stock of voluntary pension contributions, only the flow, we only use the change in financial assets in the analysis. The changing value of household real estate is measured with substantial noise and most of the variation is not driven by household wealth accumulation decisions, so we explore that separately. ${ }^{19}$ Our measure is meant to capture wealth accumulation decisions by the household, not their total wealth, so it does not include the current discounted value of human capital (ex. income), mandatory pension contributions, etc. Apart from income, we do not expect any of these to change systematically around the reform. We explore income separately.

\footnotetext{
${ }^{18}$ In the Netherlands, most pension contributions are mandatory and collected by employers. If these mandatory payments are below the statutory limit, individuals can make voluntary pension contributions. For tax purposes these are subtracted from a household's gross income, leading to a lower taxable income. We can observe each household's gross and taxable incomes, as well as other factors which cause differences between those two (ex. mortgage interest payments) allowing us to back out their voluntary pension contributions. We verify that that these contributions are positively correlated with household income and are generally distributed in ways consistent with maximum contribution cut-offs, providing validity for our calculations.

${ }^{19}$ Another issue is that since house prices are the discounted present value of future rental rates, house price changes may not reflect changes in wealth, if costs of living in that area rise as well. That being said, we show that our results are unchanged if we include changes in the value of real estate in our measure of wealth.
} 
Liabilities include the outstanding mortgage balance and all other liabilities. Non-mortgage liabilities are provided by CBS and are based on national credit registry data merged to the household. We define non-mortgage savings as changes in financial assets net of changes in non-mortgage liabilities.

Outstanding mortgage liabilities are based on administrative tax records from CBS filed by households and verified by banks. These data do not include information about amortization within the linked savings accounts discussed in Section 1. To overcome this issue, we use data provided by HDN of mortgage offers. This data covers around $75 \%$ of mortgage offers as of December 2014. The dataset contains detailed information on loan characteristics including the size of the mortgage and mortgage contract type (ex. fully amortizing, interest-only, etc.). As we noted previously, prior to the 2013 reform, new mortgages had to be at least $50 \%$ amortizing to be eligible for interest deductibility and national mortgage insurance. We verify that most mortgages qualified, usually with amortization through a linked savings account. In our analysis, we treat linked savings as amortization. Therefore, if in CBS we observe a mortgage without a year-over-year change in its mortgage balance, we make the assumption that the household has an (amortizing) linked savings account for $50 \%$ of their mortgage. ${ }^{20}$ We then impute the amortization the household effectively made within the linked account, assuming these mortgages amortize as an annuity, using an interest rate of $4.50 \%$. As we noted previously, households were unable to access linked savings before the end of the mortgage.

\subsection{Life Events}

Another benefit of examining this reform in the Netherlands is that CBS provides accurate and up-to-date information about household life circumstances. We use detailed information on the number of household members over time to create a sub-group of households who had "life events" between 2012 and 2013 and also bought their first home with a mortgage during that period. We define life events as any month where the number of household members changes (ex. birth of a child, death in the family, divorce, child moving out, etc.). For this sub-group, the timing of the first-home purchase is likely to by driven by the timing of the life-event and unlikely to be timed strategically to avoid the reform. We verify that the timing of lifeevents strongly predicts the timing of home purchase. We use the timing of life-events, rather than home purchase, as an instrument for the reform-induced additional mortgage amortization.

\section{Hypotheses and Empirical Design}

The main analyses in the paper are based on the following decomposition:

$$
\text { Wealth Accumulation }_{\mathrm{i}, \mathrm{t}, \mathrm{t}+1} \equiv \text { Mortgage Amortization }_{\mathrm{i}, \mathrm{t}, \mathrm{t}+1}+\text { Non-mortgage Savings }_{\mathrm{i}, \mathrm{t}, \mathrm{t}+1}
$$

\footnotetext{
${ }^{20}$ In our robustness checks, we show that results are virtually the same when we change these assumptions.
} 
where wealth accumulation for household $i$ from date $t$ to $t+1$ is equal to the mortgage amortization, including all mortgage debt repayment, plus any non-mortgage savings over that same period. Nonmortgage savings includes all other components of household wealth accumulation except mortgage repayment, including the build-up of financial assets (deposits, stocks, bonds, and voluntary pension contributions) or reductions in non-housing liabilities, such as consumer loans. A change in amortization requirements only increases wealth accumulation if it is not offset by changes in other net savings. For example, if a household is forced to amortize its mortgage with an additional $€ 1 \mathrm{k}$ in a given year, its total net wealth is only going to increase by $€ 1 \mathrm{k}$ if it does not sell stocks worth $€ 1 \mathrm{k}$, or dissave in another way.

The key aim of the paper is to establish the fungibility between different types of savings, and to provide one estimate that pins down the following two parameters:

$$
\begin{gathered}
\text { Fungibility }(F):=-\frac{\partial S}{\partial A} \\
\text { Marginal Wealth from Amortization (MWA) }:=\frac{\partial W}{\partial A}:=1-F
\end{gathered}
$$

where $F$ is the fungibility between mortgage repayment induced by amortization and net non-mortgage savings, while MWA is the change in wealth for a change in mortgage amortization. If mortgage repayments and non-mortgage savings are treated as perfect substitutes, then $F=1$ and $M W A=1$. In that case, any changes in mortgage repayments are offset by changes in non-mortgage savings, leaving wealth accumulation unchanged. On the other hand, if $F=0$ then households do not alter their behavior in their other accounts which means increased debt repayments leads to more wealth accumulation.

To estimate these parameters, we compare outcomes over the same time period (ex. Jan-Dec 2015) for FTHBs who bought between 2012 and 2013 - comparing those who bought before vs. after the reform. As an initial exercise, we compare average mortgage repayments and wealth accumulation by month of closing relative to the average in a given month (ex. February of 2013):

$$
\begin{aligned}
A_{\text {Jan-Dec 2015,i }} & =\sum \delta_{C} \times 1_{C, i}+\eta_{i} \\
W_{\text {Jan-Dec 2015,i }} & =\sum \beta_{C} \times 1_{C, i}+u_{i}
\end{aligned}
$$

where $A$ and $W$ are mortgage repayment (amortization) and wealth accumulation, respectively. In each regression, the only independent variable is the cohort $1_{C, i}$ : the month a household closed on their house. The reform was binding for those who went under contract after January $1^{\text {st }}, 2013$. Typically, it takes two months to close. Therefore, we consider households who closed after March $1^{\text {st }}, 2013$ as treated (intent-totreat). From these estimates, we calculate $\widehat{M W A}=\frac{\bar{\beta}_{\text {treated }}-\bar{\beta}_{\text {control }}}{\bar{\delta}_{\text {treated }}-\bar{\delta}_{\text {control }}}$ using just these simple averages.

We estimate this parameter more formally with two-stage least squares (2SLS), using the closing date as an instrument for mortgage repayments. In particular, we estimate the following first stage: 


$$
A_{\text {Jan-Dec 2015,i }}=\delta_{\text {treated }} 1_{\text {treated }, i}+\lambda_{r}+X_{i}^{\prime} \beta+\eta_{i}
$$

where $A$ is debt repayment driven by mortgage amortization from January till December of 2015 for household $i, 1_{\text {treated }, i}$ is a dummy variable equal to 1 if a household $i$ closed on their house after March $1^{\text {st }}, 2013, \lambda_{r}$ are location fixed effects, and $X_{i}$ are household controls in the years prior to home purchase (ex. 2010 household gross income). If the reform increased mortgage repayment, we would expect $\delta_{\text {treated }}$ to be positive and highly statistically significant. The second stage estimates the effect of the predicted mortgage amortization from equation (6) on wealth accumulation (we run this using 2SLS to obtain the correct standard errors):

$$
W_{\text {Jan-Dec 2015,i }}=\gamma_{\text {treated }} \hat{A}_{\text {Jan-Dec 2015,i }}+\lambda_{r}+X_{i}^{\prime} \beta+u_{i}
$$

One concern is that the timing of closing may be correlated with household preferred wealth accumulation. This selection effect could bias our estimates. To address this issue, we run the same 2SLS specification from equations (6) and (7) restricted to the set of buyers who also had a life-event during this period and use the month of the life-event, not the actual month of closing, to determine whether a household is treated or not.

Wealth accumulation cannot arise out of nowhere. By definition:

$$
A_{2015, i} \equiv Y_{2015, i}-E_{2015, i}
$$

where $Y$ is after-tax income and $E$ is expenditures of household $i$. Therefore, if households accumulate more wealth because they do not fully adjust non-mortgage savings, then they must either increase their income or reduce their expenditures. We use the detailed administrative data to measures changes in income and we interpret the remaining variation as changes in expenditures.

\section{Results}

\subsection{Mortgage amortization and wealth accumulation}

We examine mortgage amortization and wealth accumulation among FTHBs who closed on their house at different times around the reform. In Figure 2, we compare the amount of mortgage repayment from January to December 2015 cohort-by-cohort following the methodology outlined in equation (4). The March 2013 cohort includes the first households to have gone under contract after the reform. The solid black line is the estimated amount of mortgage repayment relative to the omitted February 2013 cohort (the last cohort not affected by the reform). We do not include any other controls and use the full sample of FTHBs. Those who closed up to February 2013 had similar amounts of mortgage repayment in 2015. By contrast, buyers who closed in March 2013 and later have a sudden and persistent rise in amortization, flattening out at about a $€ 2 \mathrm{k}$ increase. The lack of pre-trend and sudden change around the reform suggest that "age” (the 
number of months since closing, indicated on the horizontal axis) has no effect on 2015 financial decisions in and of itself. To evaluate the economic magnitude of the effect, we scale it by median household liquid assets as of the end of 2014 (small percent values in brackets along the y-axis in Figure 2). The estimated annual increase in amortization for treated cohorts is about a quarter of the median stock of liquid assets. This implies a substantial increase in mortgage debt repayments.

Next, we examine the change in households' non-mortgage savings and the net-effect on wealth accumulation. The yellow dotted line in Figure 2 is the change in non-mortgage savings (liquid assets plus voluntary pension contributions minus non-mortgage liabilities) over 2015 for the same cohorts, again relative to the omitted February 2013 cohort. Those who closed up to February 2013 had similar amounts of non-mortgage savings in 2015. However, in contrast to the change in mortgage repayments, we find little evidence that households buying after the reform reduced their non-mortgage savings to compensate for the increased debt repayment. Households appear to act as if these accounts are infungible $(F \sim 0)$. The dashed gray line in Figure 2 shows a near 1-for-1 increase in net wealth accumulation.

In Table 2, we formalize this analysis following the 2SLS procedure outlined in equations (6) and (7). This table includes the subset of $\sim 42 \mathrm{k}$ FTHBs who closed between October 2012 and September 2013, excluding the March and April 2013 cohorts for whom it is ambiguous whether they went under contract before or after the reform. Column 1 shows that cohorts almost surely buying after the reform had a $€ 2 \mathrm{k}$ higher mortgage debt repayment in 2015. This is our first stage estimate. Columns 2 shows a nearly identical effect on wealth accumulation for the same households over the same year. Consistent with these results, column 3 gives an estimate of the marginal wealth accumulation from amortization, MWA, of 0.993, which is statistically different from 0 , but not from 1 (the 95\% confidence interval is between 0.88 and 1.10). Column 4 shows there is no statistically significant effect on non-mortgage savings. In appendix Figures A4 and A5, we separate this effect into changes in financial assets (A4) and non-mortgage liabilities (A5) - neither display an offsetting effect. ${ }^{21}$

In Table 3, we examine how households adjust to the increased mortgage repayment using the income/expenditures/savings identity from equation (8). Column 1 shows that within a given household, gross income increases by $€ 1,270 \mathrm{k}$ between 2012 and 2015 for those who bought after relative to before

\footnotetext{
${ }^{21}$ In appendix Table A1, we show that these results are robust to including an alternative measure of voluntary pension contributions that includes all imputed values (column 1), including the appraised value of real estate in our measure of wealth (column 2), including both (column 3), or running a levels-on-levels regression of the households' home equity value on net worth (total assets - liabilities) as of the end of 2015 (columns 4 and 5). Findings are also robust to using an alternative sample (Table A2), that includes even unusually large wealth (column 1) or mortgage (column 2) changes, or every single household in our sample that buys a home, including those with large changes in wealth/mortgage balances and those who are not buying a house for the first time (column 3). Findings are equally robust to varying the amortization and interest rate assumptions for unobserved linked mortgage accounts (Table A3) or the choice of method to compute standard errors (Table A4).
} 
the reform. This is about $62 \%$ of the increase in mortgage amortization and wealth accumulation in Table 2, columns 1 and 2. In appendix Tables A5 and A6, we use detailed administrative information to show that virtually of the post-reform rise in household income comes from an increase in labor supply. ${ }^{22}$ In appendix Table A5 we look at labor market participation. Columns 1 and 2 show an increase in the number of wage earners in the household, both overall and for those households with at least two working age members. Column 3 shows that the probability a household has only a single earner falls from around 27 to $25 \%$. Column 4 shows that this holds for the subset of households that experience a change in single earner status from either single earner to multi-earner or the reverse. In appendix Table A6 we look at total hours worked. Columns 1 and 2 show that hours worked are highly correlated with household income, both in levels and in changes. Columns 3 and 4 confirm that the total household hours worked increased between 2012 and 2015. Finally, column 5 shows that controlling for changes in hours worked reduces the effect of the reform on income growth to close to zero.

In columns 2 and 3 of Table 3, we formally run 2SLS regressions to look at effects of the reform on the change in gross household income. Column 2 has no controls and shows an estimate of 0.621 . Since marginal tax rates are about $42 \%$ in the Netherlands for our group of buyers, this suggests that approximately $0.621 \times(1-42 \%) \sim 36 \%$ of the increase in wealth accumulation is paid for by an increase in after-tax household income (95\% confidence interval between 22 and 51\%). Column 3 controls for financial circumstances well before the reform, in particular the log of gross household income and financial assets in 2011, and location fixed effects, and shows a similar estimate. ${ }^{23}$ In columns 4 and 5 we run 2SLS regressions looking at income levels in 2012 and 2015, respectively. Results shows that the change in income does not come from a lower income right before the reform in 2012, but from a higher income in 2015. The level-estimate in column 5 suggests that about 26\% of the increase in debt repayment was paid for by a rise in after-tax household income. Taken together, our point estimates suggest that households compensated between 26 and 36\% of the rise in mortgage amortization by increasing after-tax household income. The remainder must be driven by lower household expenditures.

\subsection{Addressing selection concerns}

Our findings are consistent with a large response of wealth accumulation to mortgage amortization. However, our estimates would be biased if households buying a home before the reform are systematically different than those buying later. In particular, demand- or -supply factors could have caused certain

\footnotetext{
${ }^{22}$ Information on hours worked by employees are mandated to be reported monthly by employers to the Ministry of Social Affairs in order to track required social benefits and are linked to the primary data sources via unique personlevel identifiers by CBS.

${ }^{23}$ For comparison, Column 6 shows that our initial estimate of MWA is unchanged if we include the same set of prereform and location controls.
} 
households, who would have bought earlier, to drop out after the reform. Alternatively, certain households may have changed the timing of home purchase in response to the reform. We provide multiple pieces of evidence suggesting that these selection concerns are not an important source of bias.

First, in appendix Figure A6, we examine the number of home closings per month for our group of buyers. There is no evidence that points to bunching around the reform. This suggests that there is no drop in the number of households who purchase a home after the reform, nor any systematic shift in the timing of purchase. ${ }^{24}$

Next, in appendix Figure A7, we examine covariate balance on observables for households buying just before or after the reform. We break-out our analysis into FTHBs and non-FTHBs (existing homeowners buying a new house) and look at the same purchase cohorts around the 2013 reform that we analyzed before. Panel A shows that the reform led to a higher additional amortization amount for FTHBs. If there is differential selection of homebuyers around the reform, we would expect to see sudden non-linear changes in co-variates right around the regulatory change that are larger for FTHBs than for non-FTHBs. Across all variables though, whether it is house value (Panel B), pre-reform liquid assets (Panel E), gross household income (Panel F), liquid asset accumulation (Panel G), or income growth (Panel H) we see no evidence of sharp non-linear changes in the co-variates of FTHBs, non-FTHBs, or in the differences between the two in the cohorts before and after the reform. ${ }^{25}$ We also see no evidence for changes in liquid assets for either group around the reform (Panels C and D). Appendix Figures A2 and A3 show that there are also no changes in the average mortgage interest rate and origination LTV and LTI ratios around the reform.

As we show in Table 3, the only difference in observables that we can find is in future income growth. Appendix Table A6 shows that this is entirely driven by the number of hours worked, likely reflecting households working more to cover the extra amortization. Expected changes in future income do not determine how much a household can borrow. Therefore, it seems unlikely that this reflects supplydriven selection where households who anticipate to work more qualify for larger mortgages and become relatively more likely to buy a house after the reform. Nevertheless, it might be possible that higher mortgage payments scare off some households who do not plan on working more hours. To make sure that this does not drive our results, we rerun our analysis for the subsample of households that cannot increase

\footnotetext{
${ }^{24}$ The spike in transactions in June of 2012 is driven by concerns about an increase in the transaction tax for new house purchases (which never materialized). This stands in stark contrast to the lack of any spike or dip around the 2013 reform, suggesting households do sometimes respond to changes in mortgage rules, but clearly did not appear to do so for this reform.

${ }^{25}$ In Panel F, there is a slow downward trend in FTHBs that is steeper than for non-FTHBs. However, there is little evidence of a sharp non-linear change around the reform. Moreover, the lack of any difference for non-FTHBs buying before vs. after (and no differential future financial asset accumulation for either group) make it unlikely this is driven by the reform.
} 
the number of hours worked because everyone aged 21 and older already works full-time (at least 35 hours per week). In Table 3 column 7, we confirm that among this group there is no statistically significant increase in future income. In column 8 we show that the MWA for this group is also close to 1 . In other words, potential selection on future income growth cannot explain our results. All in all, this suggests that there is no differential selection on observables.

To address any remaining concerns about selection on unobservables, we use a novel feature of our setting and data: the occurrence of life events. These are changes in the number of people in a household, for example the birth of a child, after which households are more likely to move. The high quality of the Dutch administrative data lets us identify the exact month such events took place.

In Table 4, column 1, we first look at all households who do not own a home at the end of 2011 and who have a life-event between 2012 and 2013. Around 16.9\% of this group owns a house by the end of 2016. We test whether this differs for households experiencing a life event before or after the reform. We find virtually no difference (the coefficient is close to zero), meaning that the reform did not change the propensity to purchase a house after a life-event. We provide more detail in appendix Figure A8 where we estimate the regression month-by-month. We see no evidence of any effect around the reform.

Next, we focus on the subset of our original sample of FTHBs who experience a life-event during the same period when they purchase their homes (2012-2013). Even if there are no changes in the overall propensity to buy a home, it is still possible that households who want to save less are able to systematically buy before the reform. If so, this would bias our estimates upwards. In Figure 3, we perform the same analysis as in Figure 2 for the subset of life-event buyers. Because sample size is smaller, we focus on cohorts grouped by quarter. We plot the effects by the quarter of the life-event, not the actual closing. The figure shows that the 2012 cohorts have the same mortgage repayment over 2015 as the omitted cohorts Q4 of 2012 and Q1 of 2013. In contrast, the 2013 cohorts have substantially higher mortgage repayments. Similar to Figure 2, increases in mortgage repayment are sudden and matched nearly one-for-one with increases in wealth accumulation over 2015.

We run this analysis formally in Table 4 using the same 2SLS methodology as before, now on the subset of buyers with life-events, using the month of their life-event rather than the closing of the home purchase as instrument. Columns 2-4 show no difference in pre-reform household income, net financial asset accumulation, or overall wealth accumulation in 2010 between households with life-events before or after the reform. Columns 5 and 6 do show significant increases in the amount of mortgage repayment and wealth accumulation. Column 7 shows that these differences are not offset by changes in the assessed value of homes, indicating it is unlikely that these effects are driven by differential home investment or better timing of purchase. Column 8 implements the same the IV specification as in Table 2, column 3. This gives an estimate of the MWA of 0.864 , which is statistically different from 0 , but not from 1 (the $95 \%$ confidence 
interval is between 0.54 and 1.19). ${ }^{26}$ One potential concern is that household records are more likely to be updated when there is a move. In that case, we would still be relying on variation that, at least in part, comes from the timing of the home purchase. To alleviate this concern, we re-run our analysis in column 9 focusing on the subset of households for whom the life-event and house transfer take place in different months. We again find an estimate of MWA close to 1 (0.931, with the 95\% confidence interval between 0.41 and 1.45). These results suggest that our MWA estimates are not biased by the differential shifting of the time of home purchase.

In sum, we find no evidence that selection, either on observables or unobservables, either through changes in the propensity to buy a house or in the timing, biases our MWA estimates.

\subsection{Addressing confounded treatment concerns}

Next, we examine whether effects might be confounded by other changes around the reform.

One potential confound might come from differences between groups at year-end that arise from the date of closing (rather than going under contract) occurring before or after year-end. One such candidate is the Dutch wealth tax that is levied on mortgage savings as of January $1^{\text {st }}$. There were no changes in the wealth tax from 2012 to 2013. However, those households who closed after January $1^{\text {st }} 2013$ might have had more non-housing savings on that date than those who closed earlier, and therefore had to pay a higher wealth tax (at 1.2\%). It is unlikely that this effect had long-lasting effects. Nevertheless, in our setting there is a straightforward way to address this issue and other issues arising from similar year-end effects. In Table 5, column 1, we re-estimate our primary specification with households that closed either in January and February or March and April 2013. As explained before, the former are less likely to be affected by the reform than the latter. Results are virtually the same as before, suggesting that any year-end policies that were based on the date of closing are unlikely to drive our results. This exercise also confirms that "age" (months since closing), which is similar for the two groups, is an unlikely confound.

Another potential confound are other effects from the reform itself. In particular, households who purchased their homes under the new rules lost part of the mortgage interest deductibility (MID). The reform mandated faster repayment, which reduced the MID amount. All else equal, this means an increase in tax liabilities. This affects both the liquidity and life-time wealth of home buyers.

There are several reasons why these effects might be small in our setting. Given the convex amortization scheme of annuity mortgages, the increase in tax liabilities predominantly accrues later in the life of the mortgage. This means that the liquidity effect will be small in the first few years of the mortgage, on average amounting to substantially less than the $€ 2000$ baseline effect we find. The life-time wealth

\footnotetext{
${ }^{26}$ We show in appendix Table A1 column 6 that we obtain consistent results running the analysis in levels of home equity on net worth as of the end of 2016 (instead of in changes) and including the appraised value of the home.
} 
effect is potentially larger. This depends on people's expectations about the future of MID, which was highly uncertain. The Dutch Council of State was concerned that the reform would lead to an unjustifiable unequal treatment of FTHBs and non-FHTBs. ${ }^{27}$ Moreover, the reform was the first substantial change in the Dutch MID regime in decades, suggesting more restrictions were to follow. ${ }^{28}$ As a result, households buying before the reform may have expected to lose part of the MID as well. As we discussed earlier, we find no evidence of bunching around the 2013 reform, but we do around a possible increase in the transaction tax in June of 2012 (appendix Figure A6). This confirms that households did not interpret the 2013 reform as a wealth shock similar to the June 2012 transaction tax. ${ }^{29}$

Nevertheless, differences in MID are still a concern worth addressing. First, we consider liquidity. In Table 5, columns 2-4, we show that our estimates of MWA are similar if we estimate it for 2014, 2016, or 2017 (rather than 2015). ${ }^{30}$ If liquidity effects from tax differences were important, we would expect to see substantial differences between those years. Also, in 2014, tax differences should have been minor since an annuity mortgage hardly amortizes anything in the first few months after origination. Nevertheless, we still find an MWA not different from 1.

Second, we explore life-time wealth effects. According to the life-time income hypothesis, the effects on consumption and savings from a one-time change in expected wealth are smoothed across the life cycle. Since the increase in tax liabilities predominantly accrues later in the life of the mortgage, we would expect households buying after the reform to permanently increase their annual savings. To make sure that this adjustment does not drive our results, we take advantage of the convexity of the amortization schedule of annuity mortgages. Each month, the amortization amount increases. In other words, our treatment grows over the life of the mortgage. This allows us to compute the increase in the mortgage debt repayment within a given household over 2014 vs. 2017. We relate this to the change in wealth

\footnotetext{
${ }^{27}$ Advies Raad van State betreffende wijziging van de Wet inkomstenbelasting 2001 en enige andere wetten in verband met de herziening van de fiscale behandeling van de eigen woning (Wet herziening fiscale behandeling eigen woning), 10 September 2012.

${ }^{28}$ In fact, starting in 2014, the maximum marginal tax rate at which people could deduct interest payments was reduced by $0.5 \%$ each year until it reached the tax rate of the lowest tax bracket. In October 2017, a new government decided to speed this up to $3 \%$ per year.

${ }^{29}$ It may also be that the MID had relatively little effect on household decisions to buy a home or not. The existing literature has been somewhat mixed with Jappelli and Pistaferri (2007) finding no effect of the MID on mortgage debt at either the extensive or intensive margin in response to an Italian reform, while Gruber et al. (2019) analyzed a reform in Denmark and found no changes in homeownership decisions, but did find changes for some households in the size of houses purchased.

${ }^{30}$ For all analyses looking at wealth accumulation over 2014, we exclude households closing near the end of 2013. Households tend to save and dissave substantial sums in the months around purchasing a home. This means that households that closed near the end of 2013 display systematically different savings patterns in 2014 than households closing at an earlier date. Since we do not have monthly savings data, we cannot adjust for this. This makes it impossible to make clean comparisons for this group. The households that remain in our treatment group all bought a home at an earlier point in 2013, closer to the implementation of the reform. If anything, this makes them a more natural comparison group for our control group of households who bought right before the reform.
} 
accumulation over the same period. Again, in Column 5, we find an estimate of MWA of about 1. This suggests that it is unlikely our effects are confounded by one-time wealth shocks occurring at the time of going under contract.

Finally, in appendix Figure A9, we compare non-FTHBs buying a new home with different remaining maturities on their mortgages. In particular, we compare buyers who lived in their prior residence for more versus less than 10 years (the average is 16 years). The second group likely had longer maturities remaining on their mortgages, and therefore faced a larger (perceived) future wealth loss from the reform's MID reduction. Nevertheless, the behavior of the two groups around the reform is virtually the same. Panels A and B show that both groups faced similar short-run changes in mortgage debt repayment around the time of the reform, and bought similar sized houses, while Panels $C$ and D show no difference in liquid asset accumulation. Also, in the HDN data there is no evidence that non-FHTBs rushed to refinance their mortgages and extend maturities before the reform. In the last quarter of 2012, only 33.4\% of non-FTHB mortgage applications were to refinance, compared to 38.9\% in the first quarter of 2013. Again, these results suggest it is unlikely that a (perceived) wealth shock from limiting the MID biases our estimates in a meaningful way.

\subsection{Results hold for unconstrained savers}

For the correct interpretation of our findings, it is important to pin down what type of households drive our results. In this section, we study whether our effect is isolated to non-savers or holds more generally.

Households with limited liquid assets might be forced to accumulate wealth since there is no easy way of undoing higher amortization payments. If such households represented the majority of cases in our sample, our results would certainly still be important, but less generally applicable. As we discuss in Section 3.2, most households in our sample have more than enough liquid assets to pay for the increased mortgage amortization. In Table 6, we confirm that our results are the same for households that do not appear to be financially constrained. Columns 1 and 2 consider households with loan-to-value ratios at the end of 2014 of less than $90 \%$ and loan-to-income ratios below 4 . In both cases, households borrow significantly less funds than they can at the time of initial home purchase, which makes it less likely that they are liquidity constrained. We find MWA estimates close to $1 .{ }^{31}$ Column 3 looks at the subset of households who either have at least €10k in liquid assets at the end of 2015 or save at least €3k in that year. Both groups would be capable of paying for the increased mortgage repayment out of their liquid assets, suggesting they are unlikely to be up against their financial constraints. Again, the MWA estimate is close to 1.

\footnotetext{
${ }^{31}$ This provides additional evidence that our effects are unlikely to be confounded by concurrent policy changes that affected maximum LTV and LTI ratios, since these groups are largely unaffected by such constraints.
} 
It is possible that households with substantial liquid assets have a high demand for precautionary savings (or for some sort of indivisible consumption in the future). In that case, this group would still be unwilling to reduce its liquid assets in response to increased mortgage debt repayments. We address this concern in Columns 4-6, focusing on households that had at least €10k in liquid assets at the end of 2011, two years before the reform. Columns 4 and 5 shows that this group had persistently more liquid assets than the rest of the sample: on average €43k more at the end of 2011, and still €26k more at the end of 2015. Nevertheless, column 6 shows that that the MWA is close to 1 for this subgroup, suggesting that even the most liquid households increased their wealth accumulation one-for-one with amortization. Finally, Column 7 shows that households with stock and bond holdings at the end of 2011 also have an MWA estimate close to one. ${ }^{32}$ It seems likely that only households who have sufficient precautionary savings invest in riskier financial assets, again suggesting that our results are not driven by households that are unable or unwilling to reduce their liquid savings. Further, it suggests that our results also hold for financially sophisticated and less risk-averse households.

Overall, our findings show that an MWA close to 1 is ubiquitous, even among unconstrained households who have substantial liquid savings, accumulate wealth or invest in riskier financial assets. This indicates that our findings are not driven by some mechanical inability among households to offset amortization, nor by households' lack of interest in accumulating wealth in the first place.

\subsection{Persistence}

\subsubsection{Accumulated wealth not reversed even five years later}

So far, we have shown that the MWA increases after the reform, even in the face of substantial additional amortization. In appendix Table A7, we show that this effect persists until the end of our sample period. Columns 1 and 2 show that over the four years from December 2013 to December 2017, FTHBs buying after the reform accumulated more than $€ 8 \mathrm{k}$ in additional home equity through increased amortization, without an offsetting reduction in non-mortgage savings, leading again to an MWA estimate not statistically different from 1. In Column 3, we compute the ratio of mortgage repayment over those four years divided by the level of all liquid assets at the end of $2017 .{ }^{33}$ We find that the increase in net-wealth due to increased amortization is on average larger than the stock of liquid assets. These results imply a high degree of persistence and indicate that households do not undo the effects of increased amortization over the length of a typical business cycle.

\footnotetext{
32 These are stock and bond holdings outside of peoples' retirement accounts.

${ }^{33}$ We exclude households with less than $€ 100$ and a ratio greater than 50 to makes sure that outliers do not drive the effects. If anything, this reduces the size and significance of the effect.
} 
Cleanly identifying when households eventually spend the additional wealth they have accumulated would require following these cohorts over the rest of their lives, and is outside the scope of this paper. That said, even if this wealth was spent immediately after the five-year period we examine, our estimates would imply trillions of dollars of additional amortization-induced wealth accumulation in the U.S. alone. Our paper therefore makes an important contribution in establishing substantial effects of amortization on household wealth, with important implications for debt repayment-savings fungibility, macroprudential policies, and the life-cycle dynamics of household savings, consumption, and labor supply decisions over the length of a typical business cycle.

\subsubsection{Additional (suggestive) evidence on even longer lasting effects}

While longer-run effects are outside the direct scope of this paper, there are some pieces of suggestive evidence that households will retain amortization-induced wealth accumulation beyond five years.

First, we explore whether effects change as households approach retirement. In Table 7, we show that our results appear to be pervasive across age groups. In Columns 1-3 we re-run our primary analysis but focus on households where the maximum age in a household is above 30, 40, and 50 respectively. In all cases we find MWA estimates close to 1 . In the Netherlands, there are few multi-generation households so it is unlikely we misclassify households. Nevertheless, in Column 4 we try to alleviate such concerns by re-running the analysis on households with a maximum age above 50, excluding households with age differences of more than 20 years. Our results are consistent.

Next, we examine whether moving represents an opportunity for households to re-lever and extract home equity to consume. Our sample includes FTHBs from 2012 and 2013 and there is only a relatively small group that buy and sell another home during our period. In appendix Table A8, we consider the subsample of 1,768 people who have resold their home by December 2016. Columns 1 and 2 show that by December 2017, those buying after the reform have substantially more home equity. Nevertheless, column 3 shows that they do not appear to extract more of this home equity when moving. This is confirmed by Columns 4 and 5, which show that these households also do not have any additional financial assets, which would be likely if there was differential home equity withdrawal. Columns 6 calculates the MWA for this group and shows that this is not statistically different from 1. In sum, household do not appear to extract home equity and re-lever around a move.

These subsample results line up well with results for Dutch homeowners overall. For all nonFTHBs over 40 who purchase a home in 2012-2013, the median LTV the year after purchase is only 86\% and the $25^{\text {th }}$ percentile is only $59 \%$, well below the median and $25^{\text {th }}$ percentile for FTHBs of $105 \%$ and $101 \%$, respectively. In other words, it does not appear that households who sell one house and buy another re-lever to anywhere near the regulatory LTV limits. Results are also consistent with general patterns in the 
U.S., where non-FHTBs do not appear to re-lever back-up to regulatory limits or to the level of FTHBs (Patrabansh 2013; Patrabansh 2015; Bai et al. 2015). In the PSID (Panel Survey of Income Dynamics) sample, we find little evidence that homeowners who sell and buy a house systematically extract home equity. ${ }^{34}$ Each $\$ 1$ of additional home equity at the time of sale is associated with on average $\$ 0.88$ of additional home equity at the time of the purchase of the new home. That would suggest most home equity accumulation is retained when moving. ${ }^{35}$ Taken together, this is suggestive that moving houses may not necessarily be an event that leads to the substantial extraction of amortization-induced home equity.

Finally, we examine households' general tendency to repay their mortgages over the life cycle. We compare the Netherlands, where pre-2013 mortgages had a substantial interest-only component, with the U.S., where most mortgages were fully amortizing. Appendix Figure A10 shows the percentage of Dutch and U.S. homeowners with relatively little liquid assets ("hand-to-mouth") that still have a mortgage as a function of age. Since these homeowners do not appear to save in general, it is especially interesting to explore to what degree they decide to retain amortization-induced home equity. Panel B shows that in both countries, FTHBs aged 25-30 typically finance their house purchase with a mortgage. Nevertheless, Dutch homeowners are much more likely to still have a mortgage later in life. In their early-to-mid 60s, about 94\% of homeowners still have mortgage debt in the Netherlands, while this is only $61 \%$ in the U.S.. Panel A shows that, if anything, Dutch FTHBs purchase a home earlier in life, giving them more time to repay their mortgages. This suggests that Dutch homeowners with interest-only mortgages do not save in a separate account to repay their mortgage, ${ }^{36}$ while American homeowners with amortizing mortgages generally do not undo the amortization through home equity withdrawals. This is supported by evidence from the PSID. Fully amortizing 30-year mortgages repay on average 3.3\% of principal per year (excluding the final year). Among U.S. non-movers in the PSID who own a home in concurrent (biannual) waves and have a mortgage in the prior wave, the average (median) mortgage balance falls by $4.4 \%$ (4.6\%). This evidence is also consistent with prior literature in public economics noting the surprising lack of home equity withdrawal following moves even among the elderly (e.g. Venti and Wise 1989). Of course, there are many other differences between the U.S. and the Netherlands apart from different amortization standards, but if these tendencies hold for those buying around the 2013 reform in the Netherlands, it would be suggestive of longer run effects on wealth accumulation.

In summary, we provide evidence that mortgage amortization causes a substantial increase in wealth accumulation in the first years after home purchase. These effects are similar across age groups and

\footnotetext{
34 This is based on families in the 1999 wave and their housing decisions from 1969-2017.

35 Fagereng et al. (2019) document a similarly important role for "passive” wealth accumulation in Norway.

${ }^{36}$ In fact, among all Dutch homeowners aged 60-65 with a mortgage, the average amount of accessible financial assets is only about $€ 26 \mathrm{k}$.
} 
for movers, suggesting that effects may persist in the longer-run. Households may eventually access some of this additional amortization-induced wealth, but comparing aggregate statistics in the Netherlands and U.S. suggest a substantial persistence across the life-cycle.

\section{Conclusion}

We provide the first empirical evidence on the effects of mortgage amortization (debt repayment) on wealth accumulation by using detailed individual-level administrative data and variation in the timing of purchase by first time home buyers around a 2013 reform in the Netherlands. We find that even five years later there is no observable change in non-mortgage savings, leading to a near 1-for-1 rise in net worth with the rise in amortization. The effects occur suddenly, and only for cohorts who are exposed to the reform. We find no evidence of bunching and results are unchanged using the timing of life-events (ex. birth of a child) as an instrument for buying before vs. after the reform. The rise in wealth accumulation is achieved through an increase in labor supply and reduction in expenditures. Our findings hold looking at households with substantial liquid assets and across a broad age range, suggesting our results hold for the general population, and not just for non-savers and the young.

Aggregate mortgage amortization is economically large, in fact similar in size to pension contributions, so the finding of a substantial effect of amortization on wealth building has important implications. Ex-ante macroprudential polices aimed at building up home equity through amortization may not significantly reduce household liquidity. Ex-post macroprudential policies that reduce principal repayments during recessions are likely to have larger effects than in standard models. Our results also suggest that homeownership is a critical driver of household wealth building when coupled with an amortizing mortgage.

\section{References}

Aaronson, D., Hartley, D., and Mazumder, B. 2017. The Effects of the 1930s HOLC “Redlining” Maps. Working Paper.

Adelino, Manuel, Felipe Severino, and Antoinette Schoar. 2016. Loan Originations and Defaults in the Mortgage Crisis: The Role of the Middle Class. The Review of Financial Studies, 29(7): 1635-1670.

Amromin, G., N. Bhutta, \& B. Keys. 2020. Refinancing, Monetary Policy, and the Credit Cycle. Annual Review of Financial Economics.

Amromin, Gene, J. Huang, C. Sialm, and E. Zhong. 2018. Complex Mortgages. Review of Finance. 22.6:1987-2007.

Anders, John. 2018. The Long Run Effects of De Jure Discrimination in the Credit Market: How Redlining Increased Crime. Working Paper.

Andersen, Steffen, Philippe d’Astous, Jimmy Martinez-Correa, and Stephen H. Shore. 2019. Responses to Saving Commitments: Evidence from Mortgage Run-offs. Working Paper.

Andersen S, Campbell JY, Nielsen KM, Ramadorai T. 2020. Sources of Inaction in Household Finance: Evidence from the Danish Mortgage Market”. Forthcoming. American Economic Review.

Appel, Ian and Jordan Nickerson. 2016. Pockets of Poverty: The Long-Term Effects of Redlining. Working Paper.

Argento, Robert, Victoria L. Bryant, and John Sabelhaus. 2014. Early Withdrawals from Retirement Accounts during the Great Recession. Contemporary Economic Policy. 33(1):1-16.

Argyle, Bronson, Christopher Palmer, and Taylor Nadauld. 2019. Monthly Payment Targeting and the Demand for Maturity. Review of Financial Studies. Forthcoming.

Attanasio, O. P , Agnes Kovacs, and Patrick Moran. 2020. Temptation and Commitment: Understanding the Demand for Illiquidity. NBER Working Paper 2794. 
Aydin, Deniz. 2019. Consumption Response to Credit Expansions: Evidence from Experimental Assignment of 45,307 Credit Lines. Working Paper.

Backman, Claes, and Chandler Lutz, 2020. The impact of interest-only loans on affordability. Regional Science and Urban Economics 80 (1).

Backman, Claes and Khorunzhina, Natalia. 2020. Interest-Only Mortgages and Consumption Growth: Evidence from a Mortgage Market Reform. Working Paper.

Backman, Claes and Peter van Santen. 2020. The Amortization Elasticity of Mortgage Demand. Working Paper.

Bai, Bing, Jun Zhu, and Laurie Goodman. 2015. A Closer Look at the Data on First-Time Homebuyers. 2015. Working paper.

Barlevy, Gadi and Jonas D.M. Fisher. 2018. Mortgages choices during the U.S. housing boom. Working Paper.

Baker, S., L. Kung, M. Pagel, and S. Meyer. 2019. Measurement Error in Imputed Consumption Data. Working Paper.

Bernstein, Asaf. 2020. Negative Home Equity and Household Labor Supply. Journal of Finance. forthcoming.

Beshears, J., Choi, J. J., Harris, C., Laibson, D., \& Madrian, B. C. 2013. Simplification and saving. Journal of Economic Behavior and Organization. 95: 130-145.

Beshears, J., Choi, J. J., Harris, C., Laibson, D., Madrian, B. C., \& Sakong, J. 2015. Self Control and Commitment: Can Decreasing the Liquidity of a Savings Account Increase Deposits?. NBER Working Paper 21474.

Beshears, John, James J. Choi, Joshua Hurwitz, David Laibson, and Brigitte C. Madrian. 2015. Liquidity in Retirement Savings Systems: An International Comparison. American Economic Review: Papers \& Proceedings 105, no. 5 (May 2015 ): $420-425$.

Beshears, J., Choi, J. J., Laibson, D., Madrian, B. C., \& Skimmyhorn, W. 2019. Borrowing to Save? The Impact of Automatic Enrollment on Debt. National Bureau of Economic Research Working Paper 25876.

Beshears, John, James Choi, Christopher Clayton, Christopher Harris, David Laibson, and Brigitte Madrian. 2019. Optimal illiquidity. Working paper. 2019

Best, Michael, James Cloyne, Ethan Ilzetzki, and Henry Kleven. 2020. Estimating the Elasticity of Intertemporal Substitution Using Mortgage Notches. Review of Economic Studies 87: 656-690.

Bhutta, Neil and Benjamin Keys. 2016. Interest Rates and Equity Extraction During the Housing Boom. 2016. American Economic Review. 106(7): 1742-1772.

Brown, Meta, Sarah Stein, and Basit Zafar. 2015. The Impact of Housing Markets on Consumer Debt: Credit Report Evidence from 1999 to 2012. Journal of Money Credit and Banking 175-213.

Brueckner, Jan K, Calem, Paul S, and Nakamura, Leonard I. 2016. House Price Expectations, Alternative Mortgage Products, and Default. Journal of Money, Credit and Banking, 48(1), 81-112

Camanho, Nelson and Daniel Fernandes. 2018. The Mortgage Illusion. Working Paper.

Campbell, John, Nuno Clara, and Joao Cocco. 2019. Structuring Mortgages for Macroeconomic Stability. Working paper.

Carroll, Christopher D., 1997. Buffer-stock saving and the life-cycle/permanent income hypothesis, Quarterly Journal of Economics 114, 433-495.

Chetty, R., J. N. Friedman, S. Leth-Petersen, T. H. Nielsen, and T. Olsen. 2014. Active Vs. Passive Decisions and Crowd-Out in Retirement Savings Accounts: Evidence from Denmark. The Quarterly Journal of Economics 129 (3) (May 9): 1141-1219.

Chiang, Y.-M., Sa-Aadu, J., 2014. Optimal mortgage contract choice decision in the presence of pay option adjustable rate mortgage and the balloon mortgage. Journal of Real Estate Finance and Economics 48, 709-753.

Charles, Kerwin and Erik Hurst. 2002. The Transition to Home Ownership and the Black-White Wealth Gap, Review of Economics and Statistics 84(2), 281-297.

Choukhmane, Taha. 2019. Default Options and Retirement Savings Dynamics. Working Paper.

Cloyne, James, Killian Huber, Ethan Ilzetzki, and Henry Kleven. 2019. The Effects of House Prices on Household Borrowing: A New Approach. American Economic Review 109: 2104-2136.

Cookson, A., E. Gilje, \& R. Heimer. 2019. Shale Shocked: The Long Run Effect of Wealth on Household Debt. Working Paper.

Cocco, Joao F., 2013. Evidence on the benefits of alternative mortgage products. Journal of Finance 68 (4), 1663-1690.

Cooper, Daniel. 2013. House Price Fluctuations: The Role of Housing Wealth as Borrowing Collateral. Review of Economics and Statistics, 95(4): 1183-1197.

Cox, R., Brounen, D., Neuteboom, P., 2015. Financial literacy, risk aversion and choice of mortgage type by households. Journal of Real Estate Finance and Economics 50, 74-112

d'Astous, Philippe. 2019. Responses to an Anticipated Increase in Cash-on-Hand: Evidence from Term Loan Repayments, Journal of Banking and Finance, 108.

DeFusco, Anthony. 2018. Homeowner Borrowing and Housing Collateral: New Evidence from Expiring Price Controls. 2018. The Journal of Finance, 73(20): 523-573.

DeFusco, Anthony and John Mondragon. 2019. No Job, No Money, No Refi: Frictions to Refinancing in a Recession. Forthcoming at Journal of Finance.

DeFusco, Anthony, Stephanie Johnson, and John Mondragon. 2020. Regulating Household Leverage, Review of Economic Studies 87(2), 914-958.

Di Maggio, Marco, Kermani, Amir, Keys, Benjamin J, Piskorski, Tomasz, Ramcharan, Rodney, Seru, Amit, and Yao, Vincent. 2017. Interest rate pass-through: Mortgage rates, household consumption, and voluntary deleveraging. American Economic Review, 107(11), 3550-88.

Disney, Richard, Gathergood, John, and Henley, Andrew. 2010. House Price Shocks, Negative Equity, and Household Consumption in the United Kingdom. Journal of European Economic Association. 8(6): 1179-1207.

Dokko, J., B. Keys, \& L. Relihan. 2019. Affordability, Financial Innovation, and the Start of the Housing Boom. Working Paper. 
Dutch Banking Association (NVB). 2014. The Dutch Mortgage Market.

Engelhardt, G. V. 1996. House Prices and Home Owner Saving Behavior. Regional Science and Urban Economics, 26, 313-336.

Fagereng, Adreas, Martin Blomhoff Holm, Benjamin Moll, and Gisle Natvik. 2019. Saving Behavior Across the Wealth

Distribution: The Importance of Capital Gains. NBER Working Paper 26588.

Farrell, Diana, Fiona Greig, and Chen Zhao. 2020. The Housing Wealth Effect in the Post-Great Recession Period: Evidence from Big Data. Working Paper.

Feinstein, J, McFadden D. 1989. The dynamics of housing demand by the elderly: wealth, cash flow and demographic effects. The economics of aging. University of Chicago Press.

Friedman, Milton. 1957. A Theory of the Consumption Function. Princeton University Press (Princeton, NJ).

Ganong, Peter and Pascal Noel. 2020. Liquidity vs. Wealth in Household Debt Obligations: Evidence from Housing Policy in the Great Recession. Forthcoming American Economic Review.

Garcia, Isidoro, Paolina Median, and Michaela Pagel. 2020. Does Saving Cause Borrowing? Working Paper.

Gathergood, J., Weber, J., 2017. Financial literacy, present bias and alternative mortgage products. Journal of Banking \& Finance 78, 58-83.

Goldsmith-Pinkham, Paul and Kelly Shue. 2020. The Gender Gap in Housing Returns. Working Paper.

Gruber, Jonathan, Jensen, Amalie, Kleven, Henrik, 2019. Do People Respond to the Mortgage Interest Deduction? QuasiExperimental Evidence from Denmark. Forthcoming. American Economic Journal: Economic Policy.

Guren, Adam, Arvind Krishnamurthy, and Timothy McQuade. 2019. Mortgage Design in an Equilibrium Model of the Housing Market. Forthcoming at The Journal of Finance.

Guren, Adam, Alisdair McKay, Emi Nakamura, and Jon Steinsson. 2020. Housing Wealth Effects: The Long View. Review of Economic Studies. Forthcoming.

Hertzberg, Andrew, Andres Liberman, and Daniel Paravisini. 2018. Screening on Loan Terms: Evidence from Maturity Choice in Consumer Credit. Review of Financial Studies, 31: 3532-3567.

Hershfield, Hal, Stephen Shu, and Shlomo Benartzi. 2019. Temporal Reframing and Participation in a Savings Program: A Field Experiment. Working Paper.

Hundtofte, Sean, Arna Olafsson, and Michaela Pagel. 2018. Credit Smoothing. Working Paper.

Hurd, Michael and Constantijn Panis. 2006. The Choice to Cash Out Pension Rights at Job Change or Retirement. Journal of Public Economics 90 (12):2213-2227.

Jappelli, Tullio and Luigi Pistaferri. 2007. Do People Respond to Tax Incentives? An Analysis of the Italian Reform to the Deductibility of Home Mortgage Interests. European Economic Review, 51, 247-271.

Kaplan, Greg, Violante, Giovanni L., Weidner, Justin. 2014. The Wealthy Hand-to-mouth. Brookings papers on economic activity, pp. 77-153.

Keys, Benjamin, Devin G. Pope, and Jaren C. Pope. 2016. Failure to Refinance. Journal of Financial Economics.122(3): $482-499$.

Keys, Benjamin and Jialan Wang. 2019. Minimum Payments and Debt Paydown in Consumer Credit Cards. Journal of Financial Economics. 131 (3): 528-548.

Koijen, R. S. J., van Nieuwerburgh, S., Vestman, R., 2015. Judging the quality of survey data by comparison with truth as measured by administrative records: Evidence from Sweden. In: Carroll, C. D., Crossley, T. F., Sabelhaus, J. (eds.), Improving the Measurement of Consumer Expenditures, The University of Chicago Press, chap. 11.

Kovacs, Agnes and Patrick Moran. 2020. Breaking the commitment device: The effect of home equity withdrawal on consumption, saving, and welfare. Working paper.

Kovacs, Agnes, H. Low, \& P. Moran. 2020. Estimating Temptation and Commitment Over the Life-Cycle. Working paper.

Krimmel, Jacob. 2018. Persistence of Prejudice: Estimating the Long Term Effects of Redlining. Working Paper.

Krivo, Lauren J., and Robert L. Kaufman. 2004. Housing and Wealth Inequality: Racial Ethnic Differences in Home Equity in the United States, Demography 41(3), 585-605.

Kuchler, Andreas. 2015. Loan types, leverage, and savings behaviour of Danish households. Working Paper.

Kuchler, Theresa and Michaela Pagel. 2019. Sticking To Your Plan: Empirical Evidence on the Role of Present Bias for Credit Card Debt Payment. Journal of Financial Economics. Forthcoming.

Kueng, Lorenz. 2018. Excess Sensitivity of High-Income Consumers. The Quarterly Journal of Economics, 133(4):1693-1751.

Kuhn, Peter, Peter Kooreman, Adriaan Soetevent, and Arie Kapteyn. 2011. "The Effects of Lottery Prizes on Winners and Their Neighbors: Evidence from the Dutch Postcode Lottery." American Economic Review, 101 (5): 2226-47.

LaCour-Little, Michael and Jing Yang. 2010. Pay Me Now or Pay Me Later: Alternative Mortgage Products and the Mortgage Crisis. Real Estate Economics 38.4: 687-732.

Laibson, D., 2015. Why Don't Present-Biased Agents Make Commitments? American Economic Review 105, $267-272$.

Larsen, L., Munk, C., Sejer Nielsen, R., \& Rangvid, J. 2018. How do homeowners use interest-only mortgages? Working paper.

Leth-Petersen, S. 2010. Intertemporal consumption and credit constraints: Does total expenditure respond to an exogenous shock to credit? American Economic Review, 100(3):1080-1103.

Lusardi, Annamaria, and Olivia Mitchell. 2007. Baby boomer retirement security: The roles of planning, financial literacy, and housing wealth. Journal of Monetary Economics54, 205-224.

Madrian, B. C. and D. F. Shea. 2001. The power of suggestion: Inertia in 401 (k) participation and savings behavior. The Quarterly journal of economics 116(4), 1149-1187.

Mian, Atif, and Amir Sufi. 2009. The consequences of mortgage credit expansion: Evidence from the U.S. mortgage default crisis. Quarterly Journal of Economics 124:1449-96. 
Mian, Atif, Kamalesh Rao, and Amir Sufi. 2013. Household Balance Sheets, Consumption, and the Economic Slump. Quarterly Journal of Economics 127(3): 1687-1726.

McGee, Rory. 2019. Old Age Savings and House Price Shocks. Working Paper.

Modigliani, F. and Brumberg, R. H. 1954. Utility analysis and the consumption function: An interpretation of cross-section data, pages 388-436. New Brunswick, NJ. Rutgers University Press.

Olafsson, Arna and Michaela Pagel. 2018. The Liquid Hand-to-Mouth: Evidence from Personal Financial Management Software. Review of Financial Studies.

Piskorski, Tomasz, and Amit Seru. 2018. Mortgage Market Design: Lessons from the Great Recession. Brookings Papers on Economic Activity.

Poterba, James. S.F. Venti, and D.A. Wise. 1995. Do 401(k) contributions crowd out other personal saving? Journal of Public Economics 58.1: 1-32.

Poterba, James. S.F. Venti, and D.A. Wise. 1996. How Retirement Saving Programs Increase Saving. Journal of Economic Perspectives 10.4: 91-112.

Poterba, James, S. F. Venti, and D. A. Wise. 2013. The Drawdown of Personal Retirement Assets. NBER Working paper 16675.

Parker, Jonathan, Nicholas Souleles, David Johnson, and Robert McClelland. October 2013. Consumer Spending and the Economic Stimulus Payments of 2008, 103(6): 2530-53.

Parker, Jonathan. October 2017. Why Don't Households Smooth Consumption? Evidence from a 25 million dollar experiment. American Economic Journal: Macroeconomics, 9(4), 153-183.

Patrabansh, Saty. 2013. A Study of First-Time Homebuyers. FHFA Mortgage Market Note 13-01.

Patrabansh, S. 2015. Marginal Effect of First-Time Homebuyer Status on Mortgage Default and Prepayment. Working Paper.

Piskorski, T., Tchistyi, A., 2010. Optimal mortgage design. Review of Financial Studies 23, 3098-3140.

Schlafmann, Kathrin. 2020. Housing, Mortgages, and Self Control. Review of Financial Studies. Forthcoming.

Scholnick, Barry, 2013. Consumption Smoothing after the Final Mortgage Payment: Testing the Magnitude Hypothesis. Review of Economics and Statistics, 95(4): 1444-1449.

Skinner, Jonathan. 1994. Housing and Saving in the United States. In Housing Markets in the United States and Japan, edited by Yukio Noguchi and James Poterba. University of Chicago Press.

Skinner, Jonathan. 1995. Is Housing Wealth a Sideshow?. Advances in the Economics of Aging.

Sinai, Todd and Nicholas S. Souleles. 2005. Owner-Occupied Housing as a Hedge Against Rental Risk. The Quarterly Journal of Economics 120(2):763-789.

Stein, Luke and Constantine Yannelis. 2020. Financial Inclusion, Human Capital, and Wealth Accumulation: Evidence from the Freedman's Savings Bank. The Review of Financial Studies.

Struyven, Daan. 2015. Essays on housing and credit markets. Dissertation.

Svensson, Lars. 2019. Amortization Requirements, Distortions, and Household Resilience. Working Paper.

Svensson, Lars. 2020. Macroprudential Policy and Household Debt: What is Wrong with Swedish Macroprudential Policy? Nordic Economic Policy Review 111-167.

Thaler, Richard H., 1990. Saving, Fungibility, and Mental Accounts. Journal of Economic Perspective 193-205.

Thaler, Richard H., and Cass R. Sunstein. 2009. Nudge: Improving decisions about health, wealth, and happiness. New Haven, CT: Yale University Press.

Van Bekkum, Sjoerd, Marc Gabarro, Rustom Irani, and Jose-Luis Peydro. 2019. Take it to the limit? The Effects of Household Leverage Caps. Working Paper.

Vihriala, Erkki. 2021. Commitment in debt repayment: evidence from a natural experiment. Working paper.

Venti, S.F., and D.A. Wise. 1989. Aging, Moving, and Housing Wealth. The Economics of Aging, University of Chicago Press.

Venti, S.F., and D.A. Wise. 1990. But They Don’t Want To Reduce Home Equity. Issues in the Economics of Aging, University of Chicago Press.

Venti, S.F., and D.A. Wise. 2002. Aging and housing equity. Innovations in retirement financing, U Penn Press.

Venti, S.F., and D.A. Wise. 2004. Aging and housing equity: another look. Perspectives in the economics of aging, University of Chicago Press.

Wang, Yanwen, Muxin Zhai, and John G. Lynch. 2019. Generous to a Fault? The Effect of Generosity of Employers’ Retirement Plan Contributions on Leakage from Cashing Out at Job Separation. Working Paper.

Zator, Michal. 2019. Working More to Pay the Mortgage: Household Debt, Consumption Commitments, and Labor Supply. Working paper. 


\section{Figure 1. Percentage of New Mortgage Offers Fully Amortizing}

This figure shows the percentage of new mortgage offers in the Netherlands that are fully amortizing by offer date in each month from 2011 to 2014. The red dashed line indicates the implementation of the 2013 reform examined in this paper that discouraged the use of interest-only loans.

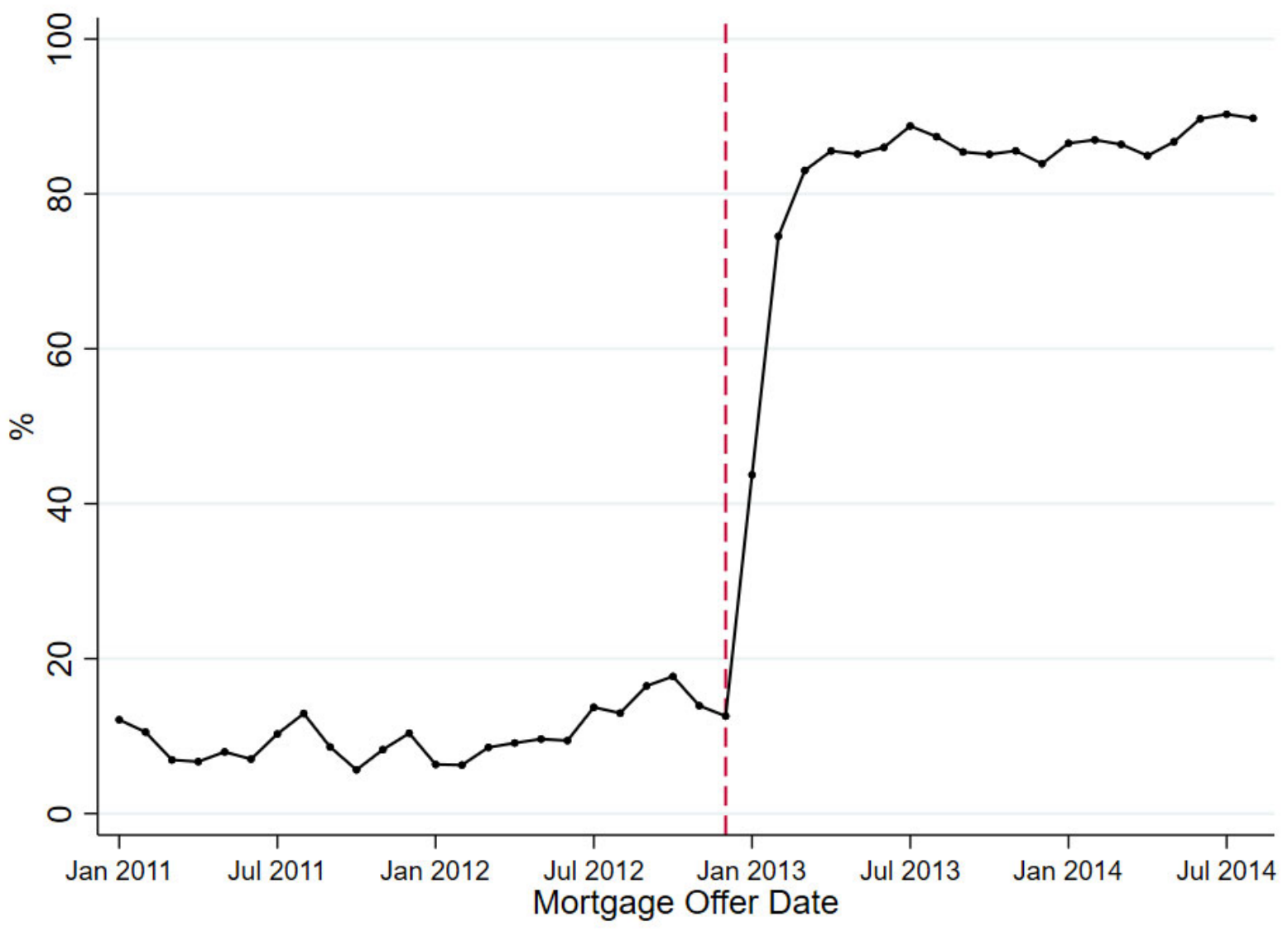




\section{Figure 2. Mortgage Amortization \& Wealth Accumulation in 2015 by Date of the Closing of Home Purchase: First Time Home Buyers ’12-'13}

This figure shows the effect of mortgage amortization on wealth accumulation using variation in the timing of the closing of home purchase for first-time home buyers around the 2013 reform, following Equations 4 and 5 in the paper. The sample includes all first-time home buyers in the Netherlands who closed on their home between April 2012 and December 2013. In particular, we regress mortgage repayment (solid black line), wealth accumulation (gray dashed line), and non-mortgage savings (yellow dotted line), all from January to December 2015, on categorical dummy variables for each cohort (month of closing on the house), where February 2013 is the omitted month. No other control variables are included. Each dot is the estimate for the relative effect each month, with 95\% confidence intervals plotted for each point. The smaller values in parentheses on the $y$-axis are the coefficients divided by the median household liquid assets as of the beginning of 2015. This simply scales the effect to demonstrate its economic magnitude and is not part of the actual analysis. The $\mathrm{x}$-axis includes the cohort (month of closing) and the age (months from closing till the beginning of 2015). Confidence intervals are based on heteroskedasticity robust standard errors clustered at the household level.

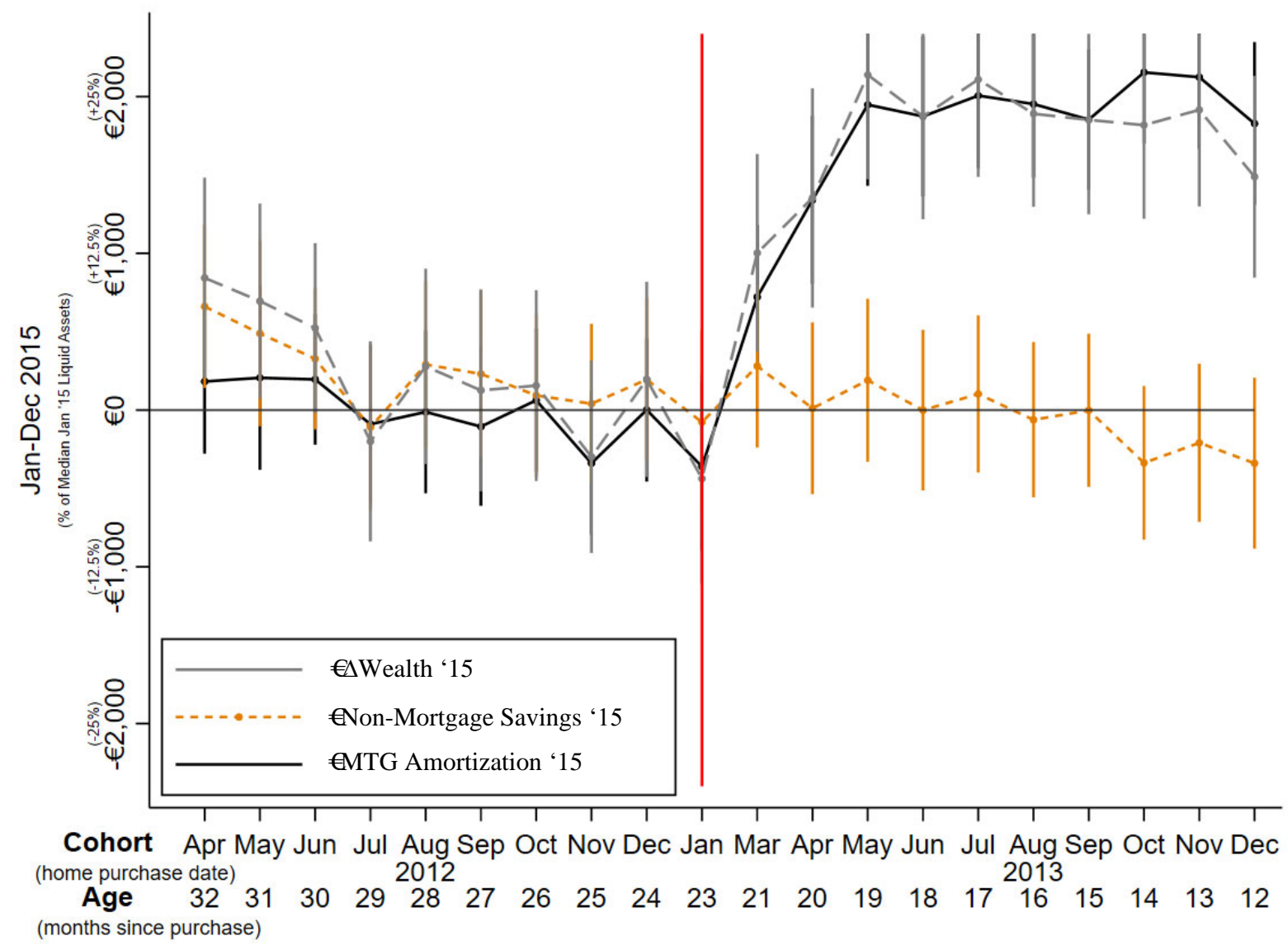




\section{Figure 3. Mortgage Amortization \& Wealth Accumulation in 2015 by Date of Life-Event: First Time Home Buyers '12-'13 w/ Life-Event}

This figure shows the effect of mortgage amortization on wealth accumulation using the timing of a "life-event" as an instrument for the timing of the closing of home purchase around the 2013 reform. The sample includes all first-time home buyers in the Netherlands who closed on their home from Q1 2012 to Q4 2013 and who experienced a life-event during this period. Life-events are defined as quarters with changes in the number of members of a household (ex. birth of a child). In particular, we regress mortgage repayment (black) and wealth accumulation (gray), both from January to December 2015, on categorical dummy variables for each life-event cohort (quarter of a life-event), where Q4 2012 and Q1 2013 are the omitted quarters. No other control variables are included. Each dot is the estimate for the relative effect each month, with 95\% confidence intervals plotted for each point. The smaller values in parentheses on the y-axis are the coefficients divided by the median household liquid assets as of the beginning of 2015. This simply scales the effect to demonstrate its economic magnitude and is not way part of the actual analysis. The xaxis includes the cohort (quarter of life-event) and the age (quarters from life-event till the beginning of 2015). Confidence intervals are based on heteroskedasticity robust standard errors clustered at the household level.

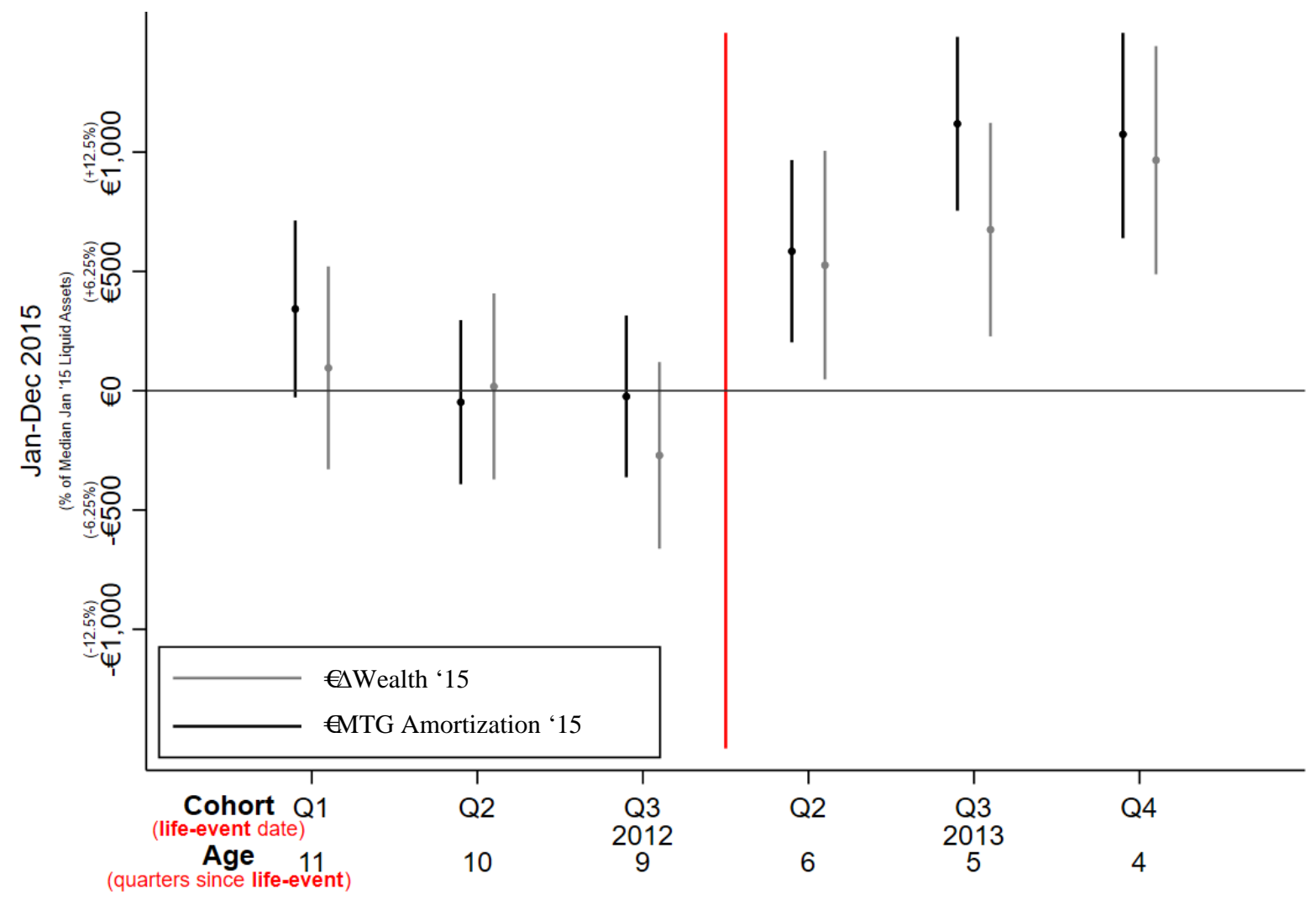




\section{Table 1. Summary Statistics for Home Buyer Cohorts ’12-’13}

The table presents summary statistics for 2014 from the CBS administrative datasets for home buyers in 2012 and 2013 in the Netherlands, who financed their purchase with a mortgage. Panel A is for first-time home buyers only. It includes the population of all buyers in the Netherlands who we can identify as having no house or mortgage prior to these years, but do afterwards. We use this sample in Figure 2. In subsequent figures and tables, we use sub-samples of households who bought a house closer to the 2013 reform. Throughout the paper and below we distinguish three measures of savings. Liquid assets $=$ all bank deposits (checking + savings + other $)+$ stocks + bonds + other marketable securities. $\Delta$ Financial assets $=\Delta$ liquid assets + voluntary pension contributions. Non-mortgage savings $=\Delta$ Financial assets $-\Delta$ non-mortgage liabilities. We do not have a measure of the level of voluntary pension assets, only the yearly flow so we can only measure financial assets and non-mortgage savings in yearly flows, while liquid assets we can measure in both levels and flows. Panel B gives information for the subset of home buyers in Panel A who also have at least $€ 10,000$ as of the end of 2015 or accumulate at least $€ 3,000$ in additional liquid assets over 2015. This corresponds to the sub-group in Table 6 column 3 but includes all buyers, not those right around the reform. Panel C includes all home buyers from 2012-2013, including those who have owned homes before (repeat buyers).

\begin{tabular}{|c|c|c|c|c|c|}
\hline \multicolumn{6}{|c|}{ Panel A. All First-time Home Buyers $(N=111,523)$} \\
\hline & Mean & Median & Stdev & $25^{\text {th }}$ & $75^{\text {th }}$ \\
\hline Mtg LTV Year-end ‘14 & 1.02 & 1.05 & 0.19 & 1.01 & 1.09 \\
\hline Mtg Balance Year-end '14 (€) & $203 \mathrm{k}$ & $187 \mathrm{k}$ & $88 \mathrm{k}$ & $151 \mathrm{k}$ & $234 \mathrm{k}$ \\
\hline Total Liabilities Year-end ‘14 (€) & $211 \mathrm{k}$ & $193 \mathrm{k}$ & $97 \mathrm{k}$ & $155 \mathrm{k}$ & $242 \mathrm{k}$ \\
\hline Income Year-end ‘14 (€) & $73 \mathrm{k}$ & $66 \mathrm{k}$ & $36 \mathrm{k}$ & $49 \mathrm{k}$ & $88 \mathrm{k}$ \\
\hline$\Delta$ Financial assets’14-15 (€) & $1.5 \mathrm{k}$ & $0.4 \mathrm{k}$ & $8.4 \mathrm{k}$ & $-1.1 \mathrm{k}$ & $3.6 \mathrm{k}$ \\
\hline Non-Mtg Savings ’14-15 (€) & $1.8 \mathrm{k}$ & $0.7 \mathrm{k}$ & $9.7 \mathrm{k}$ & $-1.5 \mathrm{k}$ & $4.5 \mathrm{k}$ \\
\hline Liquid assets Year-end ‘14 (€) & $18 \mathrm{k}$ & $7.8 \mathrm{k}$ & $34 \mathrm{k}$ & $2.6 \mathrm{k}$ & $21 \mathrm{k}$ \\
\hline$\Delta$ Liquid assets ${ }^{\prime} 14-15(€)$ & $1.3 \mathrm{k}$ & $0.3 \mathrm{k}$ & $8.6 \mathrm{k}$ & $-1.2 \mathrm{k}$ & $3.4 \mathrm{k}$ \\
\hline \multicolumn{6}{|c|}{ Panel B. “Savers” First-time Home Buyers $(N=49,212)$} \\
\hline Liquid assets Year-end ‘14 (€) & $35 \mathrm{k}$ & $24 \mathrm{k}$ & $39 \mathrm{k}$ & $14 \mathrm{k}$ & $41 \mathrm{k}$ \\
\hline$\Delta$ Liquid assets Year-end '14-15 $(€)$ & $3 \mathrm{k}$ & $3 \mathrm{k}$ & $9 \mathrm{k}$ & $-0.4 \mathrm{k}$ & $7.1 \mathrm{k}$ \\
\hline \multicolumn{6}{|l|}{ Panel C. All Home Buyers $(N=330,352)$} \\
\hline Liquid assets Year-end ‘14 (€) & $29 \mathrm{k}$ & $14 \mathrm{k}$ & $47 \mathrm{k}$ & $4 \mathrm{k}$ & $34 \mathrm{k}$ \\
\hline$\Delta$ Liquid assets Year-end '14-15 (€) & $1.4 \mathrm{k}$ & $0.2 \mathrm{k}$ & $10 \mathrm{k}$ & $-1.5 \mathrm{k}$ & $3.9 \mathrm{k}$ \\
\hline
\end{tabular}




\section{Table 2. Mortgage Amortization and Wealth Accumulation}

This table shows the effect of mortgage amortization on wealth accumulation using variation in the timing of home purchase for first-time home buyers around the 2013 reform. The sample includes all first-time home buyers who closed on their home between October 2012 and February 2013 (control) and May to September 2013 (treatment). The reform applied to the timing of going under contract, not closing, which typically takes at least two months. It is uncertain whether those who closed in March and April went under contract before or after January $1^{\text {st }}$. We therefore exclude them. Relative to the sample we use in Figure 2 and Table 1, this is a smaller group buying closer to the reform. Column 1 is the first stage of our two-stage least squares regression. It regresses the amount of mortgage repayment from January to December 2015 for a given household on Post, a dummy variable equal to 1 if they closed on their house after May $1^{\text {st }}$, 2013. Column 2 has the same specification as Column 1, but the dependent variable is wealth accumulation over 2015, and represents our reduced form regression. Column 3 is a combination of Columns 1 and 2, where we formally estimate a two-stage least squares regression using the dummy variable, Post, as an instrument for the amount of mortgage repayment in 2015. We estimate the effects on wealth accumulation over the same period. Column 4 has the same specification as Column 3, but looks at only non-mortgage savings as the dependent variable. T-statistics (and 95\% confidence intervals) with heteroskedasticity robust standard errors clustered at the household level are shown in parentheses (brackets). ${ }^{* * *}$, **, and * indicate statistical significance and the $1 \%, 5 \%$ and $10 \%$ level, respectively.

\begin{tabular}{|c|c|c|c|c|}
\hline & $\begin{array}{c}1^{\text {st }} \text { Stage } \\
\text { (1) } \\
\text { MTG } \\
\text { Repaid '15 }\end{array}$ & $\begin{array}{c}\text { RF } \\
(2) \\
\Delta \text { Wealth } \\
\text { '15 }\end{array}$ & $\begin{array}{c}\text { IV } \\
\text { (3) } \\
\Delta \text { Wealth } \\
\text { '15 }\end{array}$ & $\begin{array}{c}\text { IV } \\
\text { (4) } \\
\text { Non-MTG } \\
\text { Savings '15 }\end{array}$ \\
\hline Post & $\begin{array}{c}2045.0^{* * *} \\
(19.22)\end{array}$ & $\begin{array}{c}2030.8^{* * *} \\
(14.34)\end{array}$ & & \\
\hline MTG Repaid '15 & & & $\begin{array}{c}0.993^{* * *} \\
{[0.88,1.10]} \\
(17.62)\end{array}$ & $\begin{array}{c}-0.007 \\
{[-0.12,0.11]} \\
(-0.09)\end{array}$ \\
\hline IV & - & - & Post & Post \\
\hline F-Stat & - & - & 369.3 & 369.3 \\
\hline Obs & 42,468 & 42,468 & 42,468 & 42,468 \\
\hline Adj. $R^{2}$ & 0.020 & 0.011 & 0.331 & 0.002 \\
\hline
\end{tabular}




\section{Table 3. "Paying” for Wealth Accumulation}

This table shows how households alter their labor supply in order to pay for the increase in wealth accumulation caused by the rise in mortgage amortization. The sample includes all first-time home buyers who closed on their home between October 2012 and February 2013 (control) and May to September 2013 (treatment). The reform applied to the timing of going under contract, not closing, which typically takes at least two months. It is uncertain whether those who closed in March and April went under contract before or after January $1^{\text {st }}$. We therefore exclude them. Relative to the sample we use in Figure 2 and Table 1, this is a smaller group buying closer to the reform. Column 1 regresses the change in household gross income from 2012 to 2015 for a given household on Post, a dummy variable equal to 1 if they closed on their house after May ${ }^{\text {st }}$, 2013. Column 1 is a reduced form estimate of the effect of mortgage amortization on changes in household income. In Column 2, we re-run the two-stage least squares regression from Table 2, replacing the dependent variable with the change in gross household income from 2012 to 2015. Column 3 has the same specification as Column 2, but includes fixed effects for municipality and controls for the natural log of household 2010 income and liquid assets. Columns 4 and 5 have the same specification as Column 3, but look at 2012 and 2015 gross household income as dependent variables, respectively. To facilitate comparison, Column 6 replicates the estimates from Table 2, Column 3 (with the change in wealth accumulation over 2015 as dependent variable) including municipality fixed effects and additional controls. Column 7 is the same as column 3 , but restricts the sample to households where in 2011 the average hours worked among all members 21 and older was at least 35 hours per week. Column 8 is the same as column 7, but the outcome variable of interest is wealth accumulation over 2015. T-statistics (and 95\% confidence intervals) with heteroskedasticity robust standard errors clustered at the household level are shown in parentheses (brackets). ${ }^{* * *},{ }^{* *}$, and $*$ indicate statistical significance and the $1 \%, 5 \%$ and $10 \%$ level, respectively.

\begin{tabular}{|c|c|c|c|c|c|c|c|c|}
\hline & $\begin{array}{c}\text { RF } \\
(1) \\
\Delta \text { Income } \\
\text { '15-'12 }\end{array}$ & $\begin{array}{c}\text { IV } \\
(2) \\
\Delta \text { Income } \\
\text { '15-'12 }\end{array}$ & $\begin{array}{c}\text { IV } \\
(3) \\
\Delta \text { Income } \\
\text { '15-'12 }\end{array}$ & $\begin{array}{c}\text { IV } \\
(4) \\
\text { Income } \\
\text { '12 } \\
\end{array}$ & $\begin{array}{c}\text { IV } \\
(5) \\
\text { Income } \\
\text { '15 } \\
\end{array}$ & $\begin{array}{c}\text { IV } \\
(6) \\
\Delta \text { Wealth } \\
\text { '15 }\end{array}$ & $\begin{array}{c}\text { IV } \\
\text { (7) } \\
\Delta \text { Income } \\
\text { '15-'12 }\end{array}$ & $\begin{array}{c}\text { IV } \\
\text { (8) } \\
\Delta \text { Wealth } \\
\text { '15 }\end{array}$ \\
\hline Post & $\begin{array}{c}1270.1^{* * *} \\
(7.71)\end{array}$ & & & & & & & \\
\hline MTG Repaid '15 & & $\begin{array}{c}0.621^{* * *} \\
{[0.38,0.87]} \\
(4.97)\end{array}$ & $\begin{array}{c}0.576^{* * *} \\
{[0.29,0.90]} \\
(3.83)\end{array}$ & $\begin{array}{c}-0.119 \\
{[-0.39,0.04]} \\
(-1.60)\end{array}$ & $\begin{array}{c}0.457^{* *} \\
{[0.04,0.79]} \\
(2.20)\end{array}$ & $\begin{array}{c}1.022^{* * *} \\
{[0.92,1.13]} \\
(18.91)\end{array}$ & $\begin{array}{c}0.217 \\
{[-0.09,0.52]} \\
(1.38)\end{array}$ & $\begin{array}{c}0.918^{* * *} \\
{[0.75,1.08]} \\
(10.83)\end{array}$ \\
\hline Muni FE & $\mathrm{N}$ & $\mathrm{N}$ & $\mathrm{Y}$ & $\mathrm{Y}$ & $\mathrm{Y}$ & $\mathrm{Y}$ & $\mathrm{N}$ & $\mathrm{N}$ \\
\hline Add. Cntrls & $\mathrm{N}$ & $\mathrm{N}$ & Y & Y & Y & Y & $\mathrm{N}$ & $\mathrm{N}$ \\
\hline Full-time '11 & - & - & - & - & - & - & $\mathrm{Y}$ & $\mathrm{Y}$ \\
\hline IV & - & Post & Post & Post & Post & Post & Post & Post \\
\hline F-Stat & - & 369.3 & 141.6 & 141.6 & 141.6 & 355.7 & 161.2 & 161.2 \\
\hline Obs & 42,468 & 42,468 & 40,352 & 40,352 & 40,352 & 42,409 & 14,026 & 14.026 \\
\hline Adj. $R^{2}$ & 0.001 & 0.001 & -0.046 & -0.015 & -0.005 & 0.319 & 0.002 & 0.002 \\
\hline
\end{tabular}




\section{Table 4. Instrumenting for Timing of Purchase w/ Date of Life-Event}

This table shows the effect of mortgage amortization on wealth accumulation using the timing of a "life-event" as an instrument for the timing of home purchase around the 2013 reform. Life-events are defined to be months with changes in the number of members of a household (ex. birth of a child). With the exception of Column 1, the sample includes all first-time home buyers who closed on their home in 2012 or 2013 and who experienced a life-event between November 2012 and September 2013. Relative to the sample we use in Figure 3, this is a smaller group buying closer to the reform. This is an intent-to-treat analysis. Unlike Table 2 and 3, we are therefore less concerned about including households closing in March and April for whom it is uncertain whether they went under contract before or after the reform. Column 7 has the full sample of all households experiencing a life-event (not just those buying a home) that did not own a home at the end of 2011. The dependent variable is a dummy variable equal to 1 if the household owns real estate by December 2016. We regress this on a dummy variable equal to 1 if the life event occurs after, relative to before the reform. Columns 2-4 are covariate balance tests to show that the timing of the life-event does not appear correlated with pre-reform household characteristics. In particular, Column 2 regresses gross household income in 2010 on the Post(life event) dummy variable that equals 1 if the household had a life-event after March $1^{\text {st }}$, 2013. The control group are all buyers with a life-event from November 2012 to February 2013 , while the treated are those with a life-event from March to September 2013. Columns 3 and 4 have the same specification as Column 2, but with 2010 non-mortgage savings or wealth accumulation as dependent variable, respectively. Columns 5 through 7 also have the same specification as Column 2. Columns 5 uses the amount of mortgage repayment from January to December 2015 as the dependent variable. This is the first stage of the two stage least square regressions in this table. Column 6 uses wealth accumulation in 2015 as dependent variable. This is the key reduced form regression of this table. Column 7 uses the percent increase in the assessed value of the house over 2015 as dependent variable. Columns 8 gives the formal two-stage least squares regression using post-reform life-events to instrument for mortgage repayment in 2015. It uses wealth accumulation over the same period as dependent variable. Column 9 is the same as Column 8, but excludes any life-events that happen in the same month the household moves. Column 9 also excludes households with a life-event in March. A substantial fraction of these households likely went under contract before the reform and this reduces the power of the first stage, raising concerns about statistical bias. T-statistics (and 95\% confidence intervals) with heteroskedasticity robust standard errors clustered at the household level are shown in parentheses (brackets). ***, **, and * indicate statistical significance and the $1 \%, 5 \%$ and $10 \%$ level, respectively.

\begin{tabular}{|c|c|c|c|c|c|c|c|c|c|}
\hline & OLS & \multicolumn{3}{|c|}{ Covariate Balance Tests } & \multirow{2}{*}{$\begin{array}{c}1^{\text {st }} \text { Stage } \\
\text { (5) }\end{array}$} & \multirow{2}{*}{$\begin{array}{l}\text { RF } \\
(6)\end{array}$} & \multirow{2}{*}{$\begin{array}{l}\mathrm{RF} \\
\text { (7) }\end{array}$} & \multirow{2}{*}{$\begin{array}{l}\text { IV } \\
\text { (8) }\end{array}$} & \multirow{2}{*}{$\begin{array}{l}\text { IV } \\
\text { (9) }\end{array}$} \\
\hline & (1) & (2) & (3) & (4) & & & & & \\
\hline & Have Real & $\mathrm{HH}$ & $\Delta$ Financial & $\Delta$ Wealth & MTG & $\Delta$ Wealth & $\% \Delta$ Home & $\Delta$ Wealth & $\Delta$ Wealth \\
\hline & Estate '16 & Income '10 & Assets '10 & '10 & Repaid '15 & '15 & Value '15 & '15 & ‘15 \\
\hline MTG Repaid ‘15 & & & & & & & & $0.864^{* * *}$ & $0.931^{* * *}$ \\
\hline & & & & & & & & {$[0.54,1.19]$} & {$[0.41,1.45]$} \\
\hline & & & & & & & & (5.26) & (3.52) \\
\hline Post(life event) & $\begin{array}{c}-0.00002 \\
(-0.01)\end{array}$ & $\begin{array}{l}-249.5 \\
(-0.36)\end{array}$ & $\begin{array}{l}-57.89 \\
(-0.17)\end{array}$ & $\begin{array}{l}383.1 \\
(0.32)\end{array}$ & $\begin{array}{c}792.8^{* * *} \\
(4.60)\end{array}$ & $\begin{array}{c}685.2^{* * *} \\
(3.10)\end{array}$ & $\begin{array}{c}0.00261 \\
(0.02)\end{array}$ & & \\
\hline Life-Event Buyer & $\mathrm{Y}$ & $\mathrm{Y}$ & $\mathrm{Y}$ & $\mathrm{Y}$ & $\mathrm{Y}$ & $\mathrm{Y}$ & $\mathrm{Y}$ & $\mathrm{Y}$ & $\mathrm{Y}$ \\
\hline IV & - & - & - & - & - & - & - & Post(life) & Post(life) \\
\hline Life!=Move Date & - & - & - & - & - & - & - & $\mathrm{N}$ & $\mathrm{Y}$ \\
\hline F-Stat & - & - & - & - & - & - & - & 42.3 & 15.4 \\
\hline Obs & 382,374 & 16,581 & 16,559 & 16,559 & 16,581 & 16,581 & 16,581 & 16,581 & 11,363 \\
\hline Adj. $R^{2}$ & -0.000 & -0.000 & -0.000 & -0.000 & 0.003 & 0.001 & -0.000 & 0.355 & 0.360 \\
\hline
\end{tabular}




\section{Table 5. Year-end Effects, Persistence \& Convexity of Amortization Schedule}

This table analyzes the effect of increased amortization on wealth accumulation using different samples, periods and specifications. All columns report estimates from two-stage least square regressions using variation in the timing of home purchase for first-time home buyers around the 2013 reform as instrument. Column 1 replicates the regression from Table 2, Column 3, but restricts the sample to the subset of first-time home buyers who closed on their properties in the first four months of 2013. The dependent variable is wealth accumulation over 2015 and the endogenous variable is mortgage repayment over the same period, instrumented with the dummy variable, Post, that is equal to 1 if a buyer closed on their house after March $1^{\text {st }}$, 2013. The control group are all buyers who closed on their homes from January to February 2013, while the treated are those who closed from March to April 2013. Columns 2, 3, and 4 also have the same specification as Table 2, Column 3 but focus on mortgage amortization and wealth accumulation over 2014, 2016, and 2017 (rather than 2015), respectively. As before, the columns restrict the sample to first-time home buyers buying a home between October 2012 and September 2013, omitting those who closed in March and April 2013. Column 2 (2014) also excludes households who closed in September and October 2013. Households tend to save and dissave substantial sums in the months around purchasing a home. This means that households that closed near the end of 2013 display systematically different savings patterns in 2014 than households closing at an earlier date. Column 5 provides a delta-in-delta estimate. The dependent variable is the wealth accumulation from January to December 2017 minus the wealth accumulation from January to December 2014 and the endogenous variable is mortgage repayment from January to December 2017 minus mortgage repayment from January to December 2014. To boost power for a valid first stage, the column has a slightly larger sample of first-time home buyers buying a home between August (rather than October) 2012 and July 2013 and includes transactions right around the reform itself in March and April 2013. To focus on variation coming from the convex amortization schedule, we exclude cases with large changes in the mortgage repayment for 2017 relative to 2014 ( $\Delta$ MTG Repaid 2017 - $2014>€ 20 \mathrm{k}$ ) and cases with no remaining mortgage balance by the end of 2017. T-statistics (and 95\% confidence intervals) with heteroskedasticity robust standard errors clustered at the household level are shown in parentheses (brackets). $* * *, * *$, and * indicate statistical significance and the $1 \%, 5 \%$ and $10 \%$ level, respectively.

\begin{tabular}{|c|c|c|c|c|c|}
\hline & $\begin{array}{c}\text { IV } \\
(1) \\
\Delta \text { Wealth } \\
\text { '15 }\end{array}$ & $\begin{array}{c}\text { IV } \\
(2) \\
\Delta \text { Wealth } \\
\text { '14 }\end{array}$ & $\begin{array}{c}\text { IV } \\
\text { (3) } \\
\Delta \text { Wealth } \\
\text { '16 }\end{array}$ & $\begin{array}{c}\text { IV } \\
(4) \\
\Delta \text { Wealth } \\
\text { '17 }\end{array}$ & $\begin{array}{c}\text { IV } \\
\text { (5) } \\
\Delta \Delta \text { Wealth } \\
\text { '17-'14 }\end{array}$ \\
\hline MTG Repaid '15 & $\begin{array}{c}0.887^{* * *} \\
{[0.50,1.28]} \\
(4.49)\end{array}$ & & & & \\
\hline MTG Repaid '14 & & $\begin{array}{c}1.182^{* * *} \\
{[0.82,1.55]} \\
(6.32)\end{array}$ & & & \\
\hline MTG Repaid '16 & & & $\begin{array}{c}0.936^{* * *} \\
{[0.82,1.05]} \\
(15.49)\end{array}$ & & \\
\hline MTG Repaid '17 & & & & $\begin{array}{c}1.010^{* * *} \\
{[0.84,1.18]} \\
(11.67)\end{array}$ & \\
\hline $\begin{array}{l}\Delta \text { MTG Repaid } \\
\text { '17-'14 }\end{array}$ & & & & & $\begin{array}{c}1.161^{* *} \\
{[0.20,2.13]} \\
(2.36)\end{array}$ \\
\hline Control Group & $1 / 13-2 / 13$ & $10 / 12-2 / 13$ & $10 / 12-2 / 13$ & $10 / 12-2 / 13$ & $8 / 12-2 / 13$ \\
\hline Treated Group & $3 / 13-4 / 13$ & 5/13-7/13 & 5/13-9/13 & 5/13-9/13 & 3/13-7/13 \\
\hline IV & Post & Post & Post & Post & Post \\
\hline Narrow event window & $\mathrm{Y}$ & - & - & - & - \\
\hline Exclude Large $\Delta$ Repaid & - & - & - & - & $\mathrm{Y}$ \\
\hline F-Stat & 37.4 & 145.5 & 428.9 & 340.1 & 16.3 \\
\hline Obs & 15,223 & 35,148 & 38,741 & 35,120 & 35,098 \\
\hline Adj. $R^{2}$ & 0.259 & 0.098 & 0.326 & 0.295 & 0.143 \\
\hline
\end{tabular}




\section{Table 6. MWA for Unconstrained Savers}

This table restricts the analysis to households with significant savings. Columns (1)-(3) replicate the two-stage least squares regression in Table 2, Column 3, but restrict the sample to the subset of buyers with (1) a loan-to-value ratio below $90 \%$ as of the end of 2014, (2) a loan-to-gross household income ratio below 4 at the end of 2014, and (3) at least €10k in liquid financial assets at the end of 2015 or an increase in liquid assets by at least $€ 3 \mathrm{k}$ in 2015, respectively. Columns 4 and 5 look at the same sub-group of buyers in Table 2, Column 3, but the dependent variable is household liquid assets at the end of 2011 or 2015, respectively. We regress this on a dummy variable that is equal to 1 if the household has more than €10k in liquid financial assets at the end of 2011. Column 6 has the same specification as Column 1 of this table, but restricts the sample to the subset of households with at least $€ 10 \mathrm{k}$ in liquid financial assets at the end of 2011 . Column 7 is the same as Column 1, but restricts the sample to households with financial securities (stocks or bonds) at the end of 2011. T-statistics (and 95\% confidence intervals) with heteroskedasticity robust standard errors clustered at the household level are shown in parentheses (brackets). ${ }^{* *}, * *$, and * indicate statistical significance and the $1 \%, 5 \%$ and $10 \%$ level, respectively.

\begin{tabular}{|c|c|c|c|c|c|c|c|}
\hline & $\begin{array}{c}\text { IV } \\
(1) \\
\Delta \text { Wealth } \\
' 15 \\
\end{array}$ & $\begin{array}{c}\text { IV } \\
(2) \\
\Delta \text { Wealth } \\
\text { '15 }\end{array}$ & $\begin{array}{c}\text { IV } \\
\text { (3) } \\
\Delta \text { Wealth } \\
\text { '15 }\end{array}$ & $\begin{array}{c}\text { OLS } \\
\text { (4) } \\
\text { Fin. Asset } \\
\text { '11 }\end{array}$ & $\begin{array}{c}\text { OLS } \\
\text { (5) } \\
\text { Fin. Asset } \\
\text { '15 }\end{array}$ & $\begin{array}{c}\text { IV } \\
(6) \\
\Delta \text { Wealth } \\
\text { '15 }\end{array}$ & $\begin{array}{c}\text { IV } \\
\text { (7) } \\
\Delta \text { Wealth } \\
\text { '15 }\end{array}$ \\
\hline MTG Repaid '15 & $\begin{array}{c}1.315^{* * *} \\
{[0.91,1.72]} \\
(6.37)\end{array}$ & $\begin{array}{c}0.959^{* * *} \\
{[0.82,1.10]} \\
(13.76)\end{array}$ & $\begin{array}{c}0.997^{* * *} \\
{[0.84,1.15]} \\
(12.80)\end{array}$ & & & $\begin{array}{c}0.956^{* * *} \\
{[0.84,1.07]} \\
(15.87)\end{array}$ & $\begin{array}{c}1.059^{* * *} \\
{[0.79,1.33]} \\
(7.62)\end{array}$ \\
\hline FinAsset'11>10k & & & & $\begin{array}{c}43,445^{* * *} \\
(96.66)\end{array}$ & $\begin{array}{c}26,486^{* * *} \\
(81.06)\end{array}$ & & \\
\hline LTV '14 & $<0.9$ & - & - & - & - & - & - \\
\hline LTI ‘14 & - & $<4$ & - & - & - & - & - \\
\hline FinAsset'15 & - & - & $>10 \mathrm{k} \mid>3 \mathrm{k}$ & - & - & - & - \\
\hline FinAsset'11 & - & - & - & - & - & $>10 \mathrm{k}$ & - \\
\hline Stocks/Bonds‘11 & - & - & - & - & - & - & $\mathrm{Y}$ \\
\hline IV & Post & Post & Post & - & - & Post & Post \\
\hline F-Stat & 32.5 & 265.5 & 223.0 & N/A & N/A & 350.3 & 128.6 \\
\hline Obs & 5,762 & 27,569 & 22,005 & 42,468 & 42,468 & 17,268 & 8,149 \\
\hline Adj. $R^{2}$ & 0.202 & 0.328 & 0.252 & 0.243 & 0.173 & 0.302 & 0.306 \\
\hline
\end{tabular}




\section{Table 7. Pervasive Effects by Age}

This table looks at effects for households with a different age. All columns replicate the two-stage least squares regression in Table 2, Column 3 . Columns (1)-(3) restrict the sample to the subset of buyers where the oldest member of the household is older than 30, 40 or 50 years old as of the end of 2015, respectively. We exclude households where the oldest member is older than 75 years. Column 4 has the same specification as Column 3 , but excludes multi-generation households by omitting any household where the maximum age difference between any two adults is more than 20 years. T-statistics (and 95\% confidence intervals) with heteroskedasticity robust standard errors clustered at the household level are shown in parentheses (brackets). ${ }^{* * *},{ }^{* *}$, and $*$ indicate statistical significance and the $1 \%, 5 \%$ and $10 \%$ level, respectively.

\begin{tabular}{lcccc}
\hline & IV & IV & IV & IV \\
& $(1)$ & $(2)$ & $(3)$ & $(4)$ \\
& $\Delta$ Wealth & $\Delta$ Wealth & $\Delta$ Wealth & $\Delta$ Wealth \\
& '15 & '15 & '15 & '15 \\
\hline MTG Repaid '15 & $0.986^{* * *}$ & $1.074^{* * *}$ & $1.077^{* * *}$ & $1.272^{* * *}$ \\
& {$[0.86,1.11]$} & {$[0.86,1.28]$} & {$[0.70,1.46]$} & {$[0.76,1.79]$} \\
& $(15.24)$ & $(10.04)$ & $(5.55)$ & $(4.87)$ \\
\hline Age & $>30$ & $>40$ & $>50$ & $>50$ \\
GParentFilt & $\mathrm{N}$ & $\mathrm{N}$ & $\mathrm{N}$ & $\mathrm{Y}$ \\
IV & Post & Post & Post & Post \\
F-Stat & 274.2 & 105.0 & 40.6 & 25.2 \\
Obs & 34,185 & 15,668 & 6,416 & 5,268 \\
Adj. R ${ }^{2}$ & 0.327 & 0.301 & 0.289 & 0.177 \\
\hline
\end{tabular}


APPENDIX For Online Publication 


\section{Figure A1. Variability in Liquid Wealth Accumulation}

We compute the yearly change in liquid assets for the full sample of first-time home buyers from Table 1 for all years between 2006 and 2016. We determine years with declines in gross household income. We plot the coefficients from a regression of the change in liquid assets on dummy variables for the years before or after the decline in income. We include both household and year fixed effects. Vertical lines give $95 \%$ confidence intervals that are based on heteroskedasticity robust standard errors clustered at the household level.

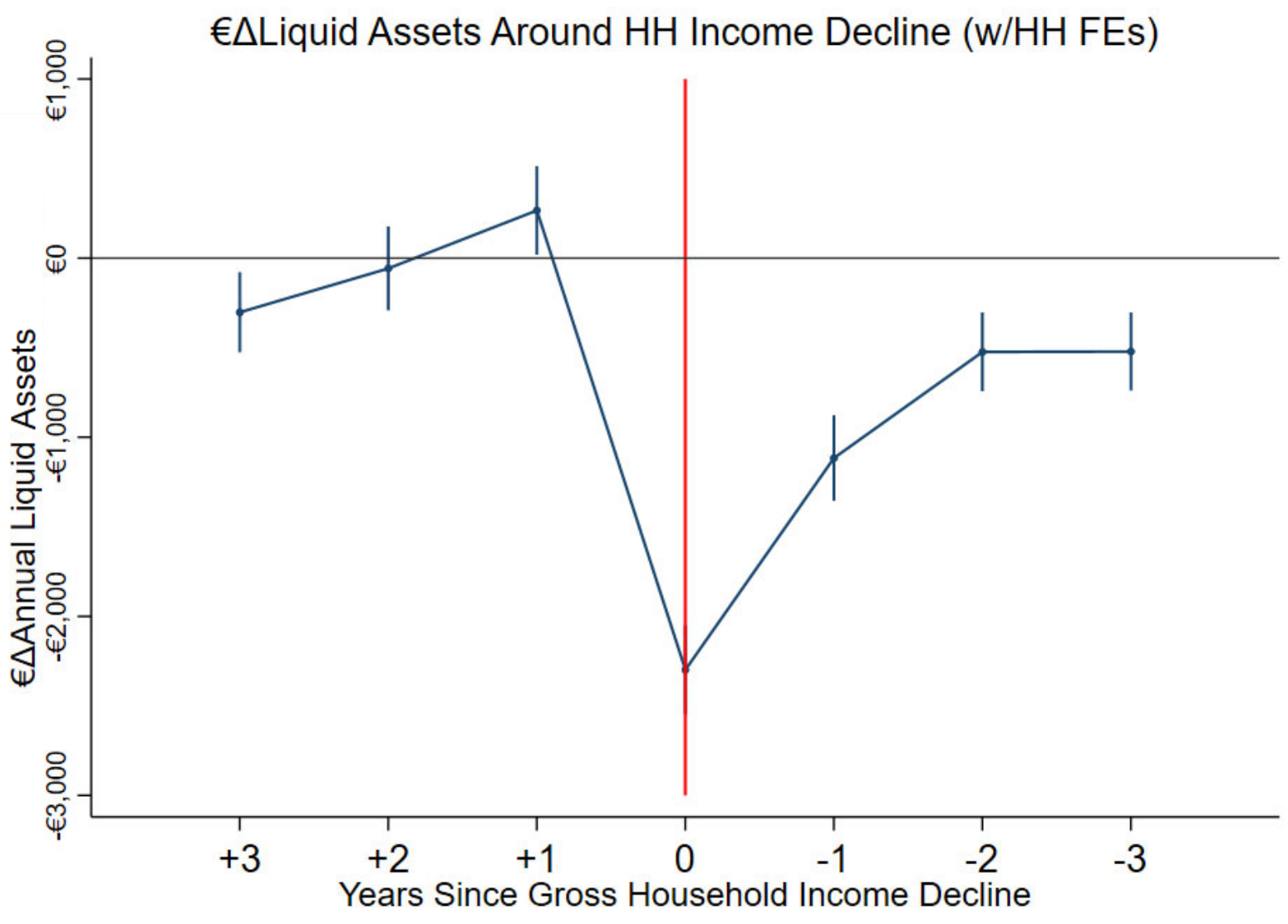


Figure A2. Dutch Macroeconomic Housing Statistics ’07-‘16

This figure present aggregate Dutch housing trends around the January 2013 reform. House prices (black line) are normalized to be 100 in 2005 and plotted on the left y-axis. Average residential mortgage interest rates (gray line) are plotted on the right y-axis. All data come from aggregate statistics publicly available from aggregate CBS data.

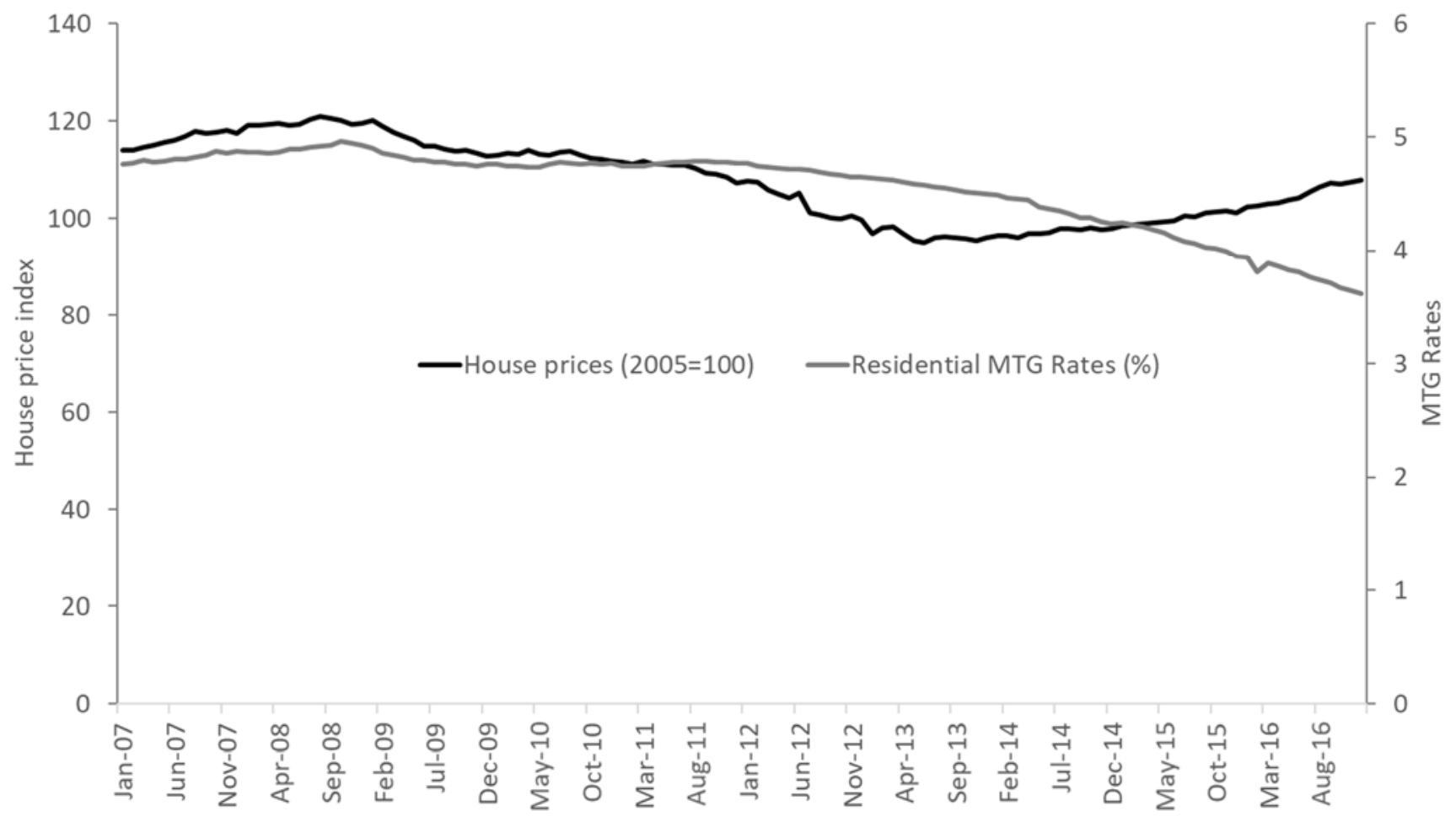




\section{Figure A3. Origination Loan-to-Value and Loan-to-Income (mean) by Mortgage Offer Date for First-Time Homebuyers 2012-2013}

This figure depicts the mean origination loan-to-value and loan-to-income of mortgage offers for first-time homebuyers in 2012 and 2013 by mortgage offer dates. Typically, the period between going under contract (at which point borrowers can formally start applying for mortgages) and closing takes at least two months. Data come from HDN and cover about 3/4s of mortgage offers as of December 2014 (see the data section of the paper for more details). The sample includes all mortgages offered to first-time homebuyers, for those aged 30 and older, where the mortgage product type is at least partially known. The new mortgage reform affected mortgages originated after December 2012 (vertical red dashed line).

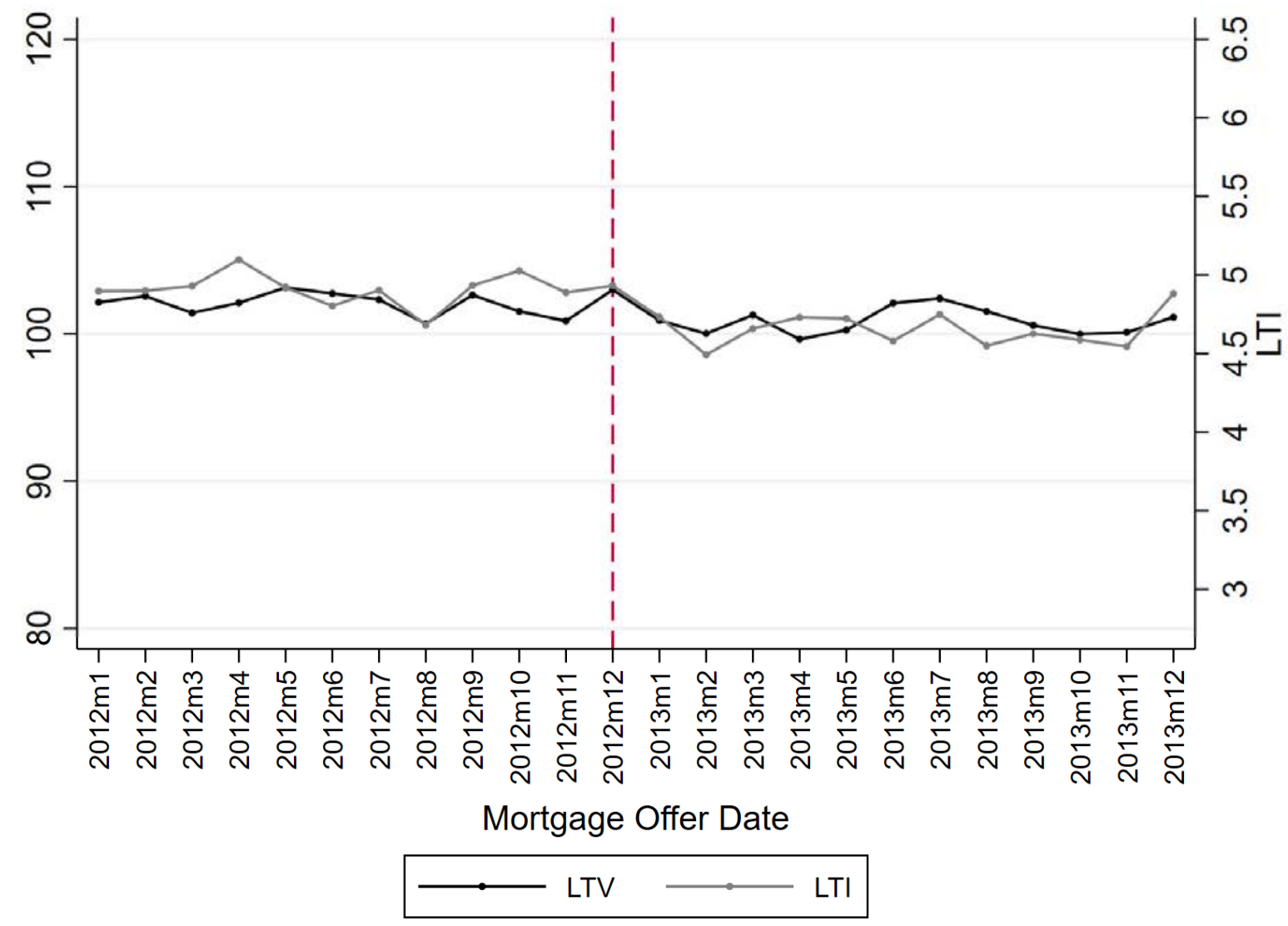




\section{Figure A4. Mortgage Amortization in 2015 \& $\Delta$ Financial Assets by Date of the Closing of Home Purchase: First Time Home Buyers ’12-'13}

This figure shows the effect of mortgage amortization on wealth accumulation using variation in the timing of the closing of home purchase for first-time home buyers around the 2013 reform. The sample includes all first-time home buyers in the Netherlands who closed on their house between April 2012 and December 2013. In particular, we regress mortgage repayment (solid black line), and change in financial assets (yellow dotted line), both from January to December 2015, on categorical dummy variables for each cohort (month of closing on the house), where February 2013 is the omitted month. No other control variables are included. Each dot is the estimate for the relative effect each month, with 95\% confidence intervals plotted for each point. The smaller values in parentheses on the y-axis are the coefficients divided by the median household liquid assets as of the beginning of 2015. This simply scales the effect to demonstrate its economic magnitude and is not part of the actual analysis. The $\mathrm{x}$-axis includes the cohort (month of closing) and the age (months from closing till the beginning of 2015). Confidence intervals are based on heteroskedasticity robust standard errors clustered at the household level.

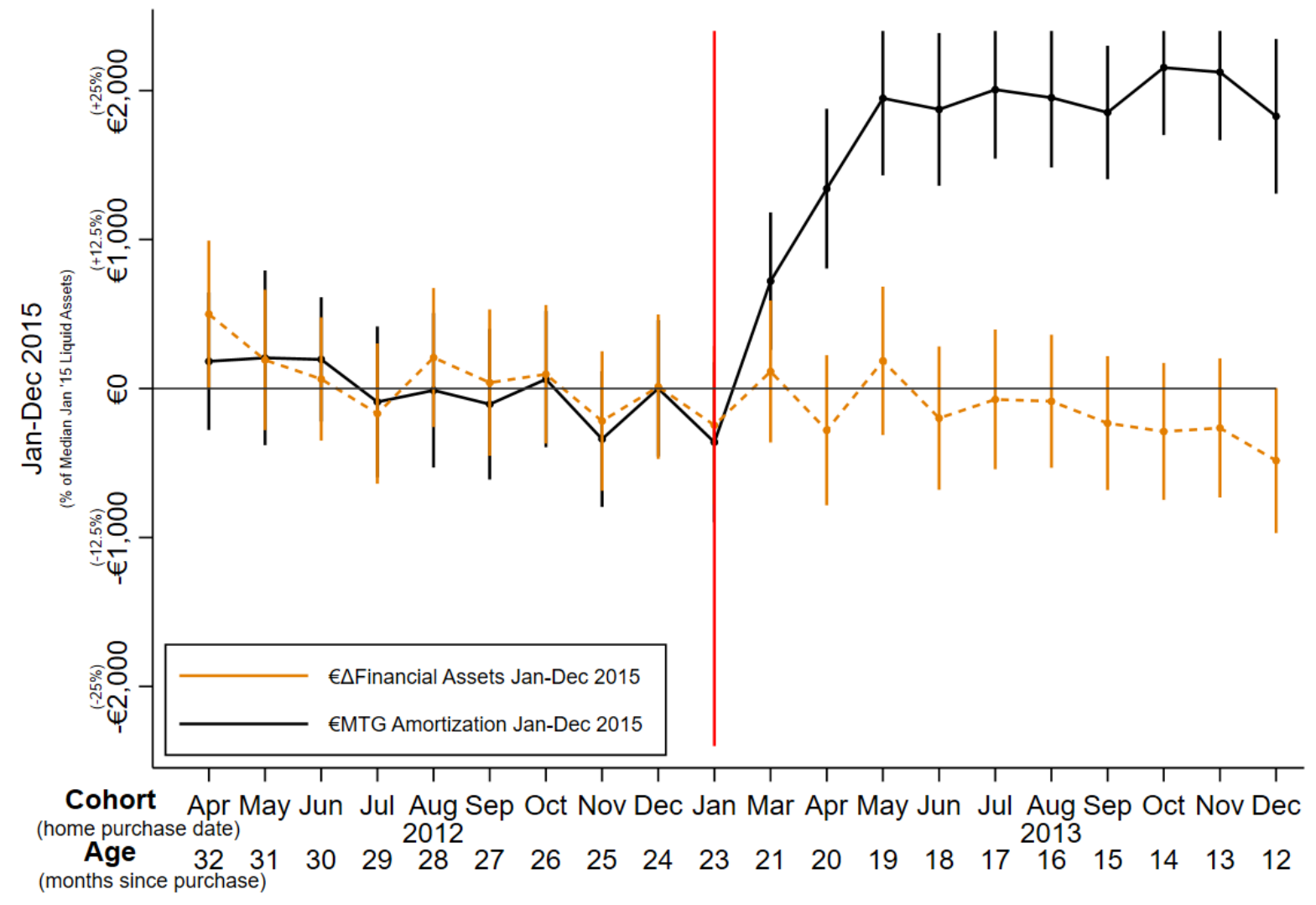




\section{Figure A5. Mortgage Amortization in 2015 \& $\Delta$ Non-MTG Liab. by Date of Closing of Home Purchase: First Time Home Buyers ’12-'13}

This figure shows the effect of mortgage amortization on wealth accumulation using variation in the timing of the closing of home purchase for first-time home buyers around the 2013 reform. The sample includes all first-time home buyers in the Netherlands who closed on their house between April 2012 and December 2013. In particular, we regress mortgage repayment (solid black line), and change in non-mortgage liabilities (yellow dotted line), both from January to December 2015, on categorical dummy variables for each cohort (month of closing on the house), where February 2013 is the omitted month. No other control variables are included. Each dot is the estimate for the relative effect each month, with $95 \%$ confidence intervals plotted for each point. The smaller values in parentheses on the $y$-axis are the coefficients divided by the median household liquid assets as of the beginning of 2015. This simply scales the effect to demonstrate its economic magnitude and is not part of the actual analysis. The $\mathrm{x}$-axis includes the cohort (month of closing) and the age (months from closing till the beginning of 2015). Confidence intervals are based on heteroskedasticity robust standard errors clustered at the household level.

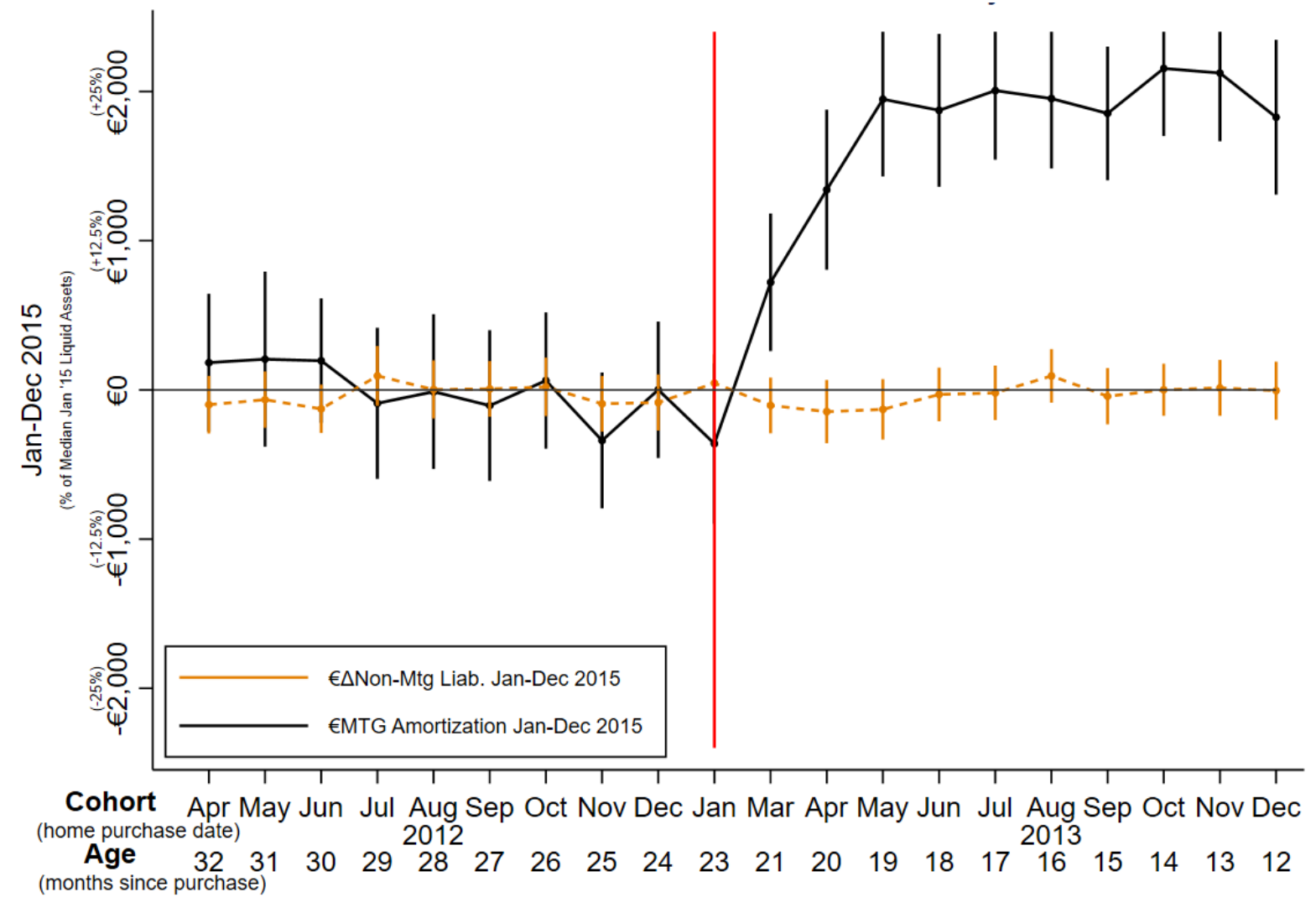




\section{Figure A6. Mortgage Amortization in 2015 \& Number of Transactions by Date of Closing of Home Purchase: First Time Home Buyers '12-‘13}

This figure compares the increase in mortgage amortization induced by the 2013 reform with the number of housing transactions in the same period. The sample includes all first-time home buyers in the Netherlands who closed on their house between April 2012 and December 2013. In particular, we regress mortgage repayment (solid black line) from January to December 2015 on categorical dummy variables for each cohort (month of closing on the house), where February 2013 is the omitted month. No other control variables are included. We also plot just the number of housing transactions for each cohort (brown solid line) in each month on the second (right) y-axis. Each dot is the estimate for the relative effect each month, with 95\% confidence intervals plotted for each point. The x-axis includes the cohort (month of closing) and the age (months from closing till the beginning of 2015). Confidence intervals are based on heteroskedasticity robust standard errors clustered at the household level. The spike of home purchases in June 2012 reflects the expected increase in in the real estate transaction tax (that never materialized).

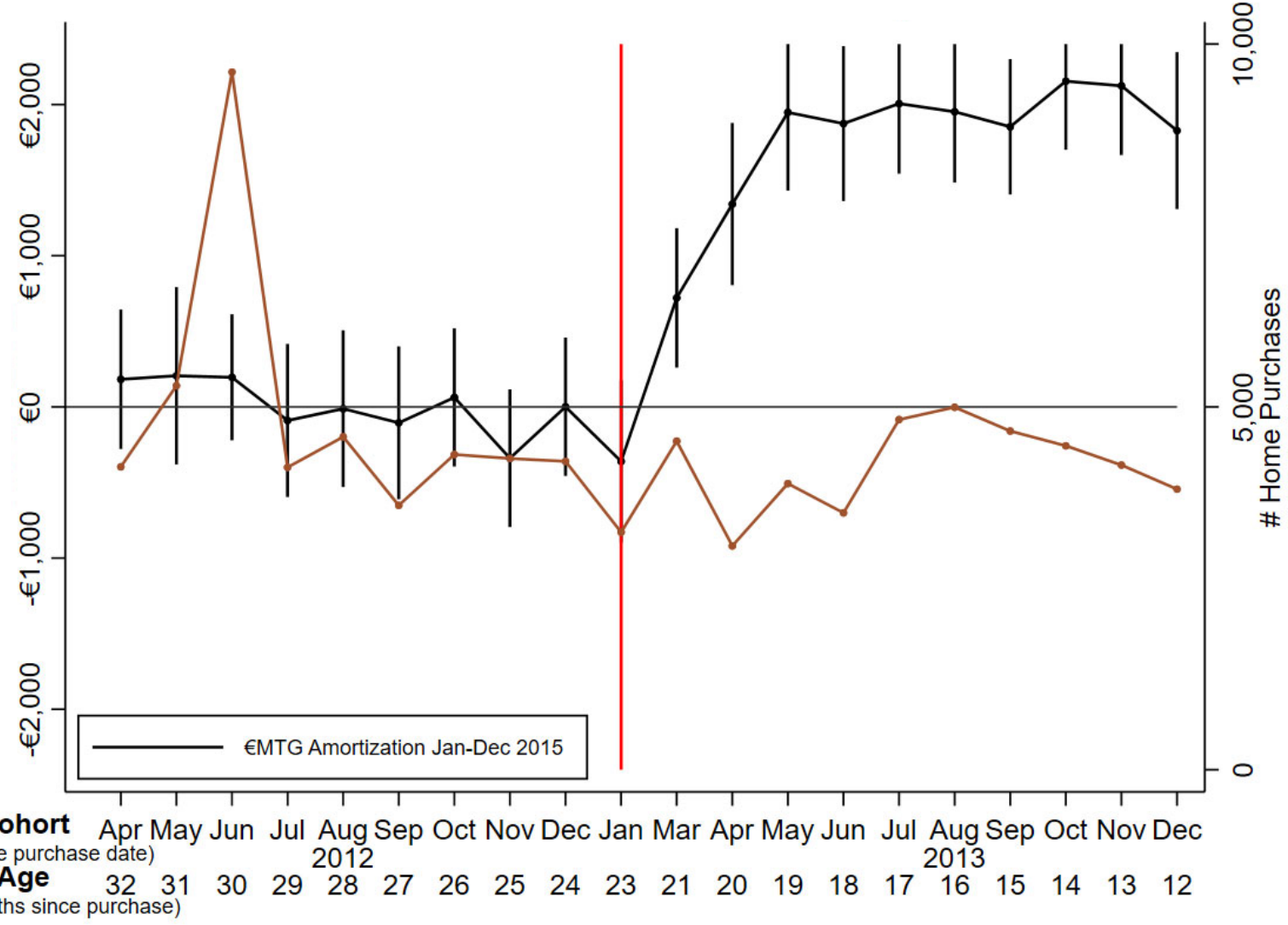




\section{Figure A7. First-Time Homebuyers vs. All Other Buyers}

This figure shows that the 2013 reform had a differential treatment effect for first-time homebuyers (FTHBs) vs. all other buyers (non-FTHBs). At the same time, there are no sharp jumps in other variables around that date, neither in absolute terms or relative to each other. We include all households buying a house between April 2012 and December 2013. FTHBs (solid black lines) and non-FTHBs (dashed yellow lines) are households without or with real estate or a mortgage in the two years prior to the reform, respectively. In panel A, we regress the percentage of the observed mortgage balance reduction, not including any amortization through linked accounts, from January to December 2015 on categorical dummy variables for each cohort (month of closing on the house), where February 2013 is the omitted month. No other control variables are included. Each dot is the estimate for the relative effect each month, with 95\% confidence intervals plotted for each point. The $\mathrm{x}$-axis has the cohort (month of closing). Panels B-H are the same as Panel A, but have different dependent variables: (B) the initial home purchase price in thousands of euros, (C) the change in the natural log of liquid assets over 2015, (D) the change in liquid assets over 2015 divided by the mortgage balance at the end of 2014, (E) the natural log of liquid assets as of Dec 2010, (F) the natural log of household gross income as of Dec 2010, (G) the change in the natural log of liquid assets over 2011, and (H) the change in the natural log of household gross income over 2011. Confidence intervals are based on heteroskedasticity robust standard errors clustered at the household level.

\section{A. Observed \% Mtg Bal Reduction '15}

B. Home Purchase Price (€000s)
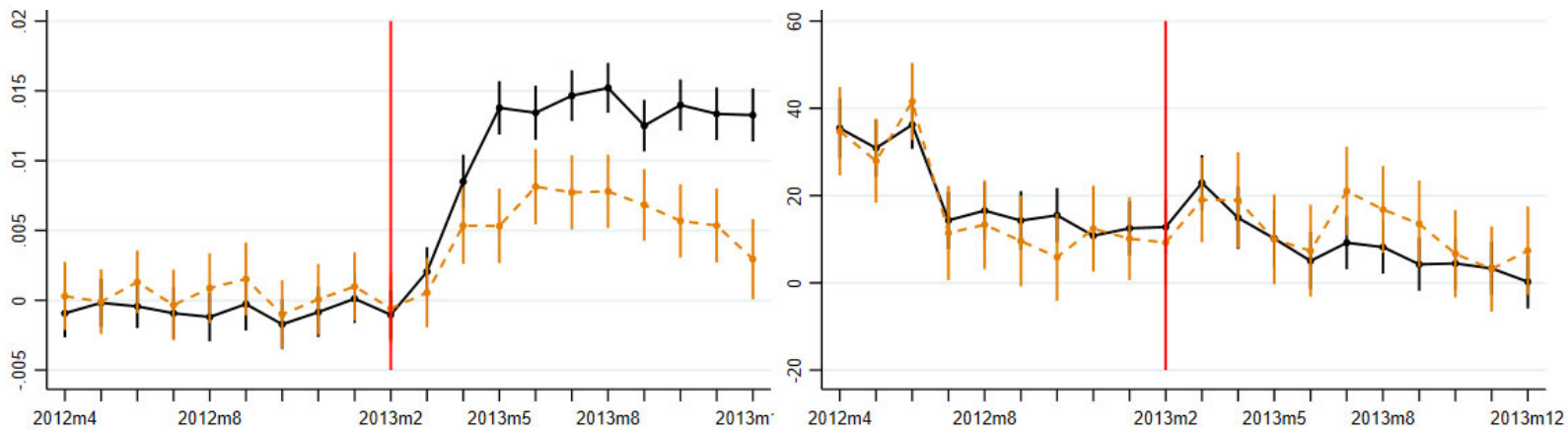

C. $\Delta$ Liquid Assets (ln) '15

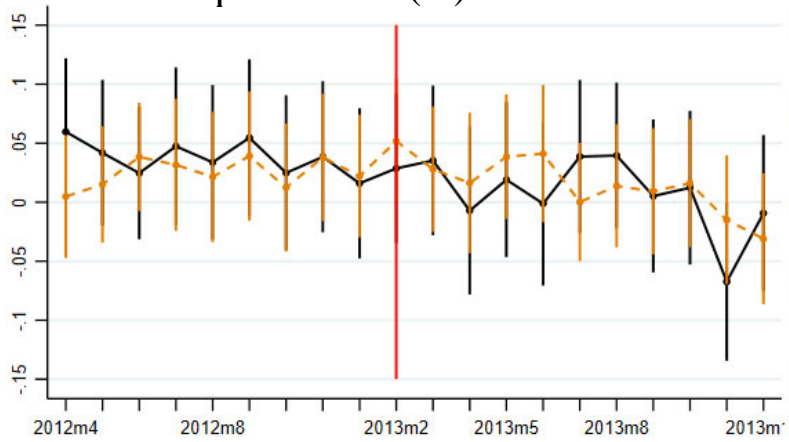

D. $\Delta$ Liquid Assets '15/Mtg Bal ‘15

\section{Closing Date}

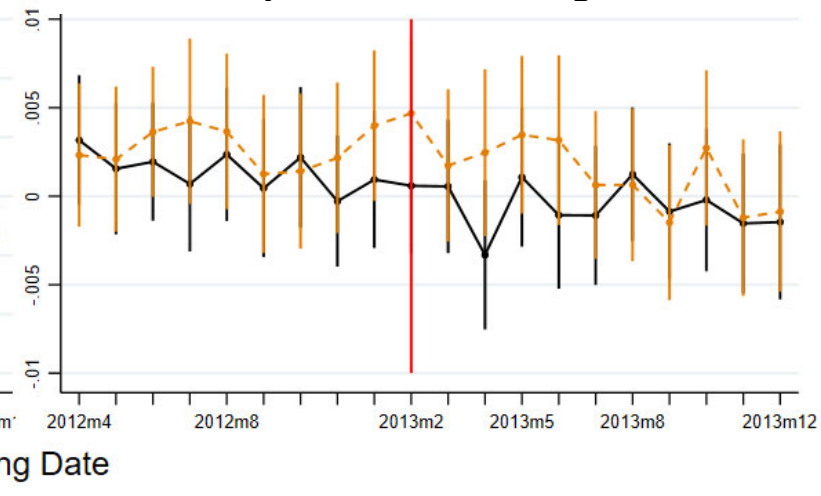


Figure A7. First-Time Homebuyers vs. All Other Buyers (Cont.)

E. Liquid Assets '10 (ln)

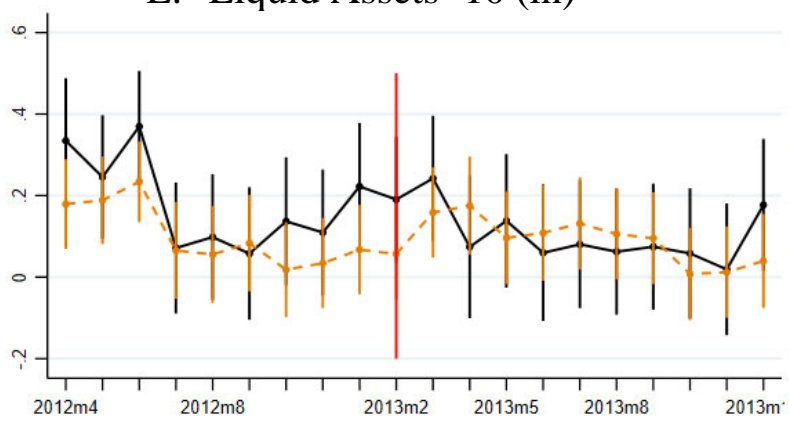

G. $\Delta$ Liquid Assets (ln) '11
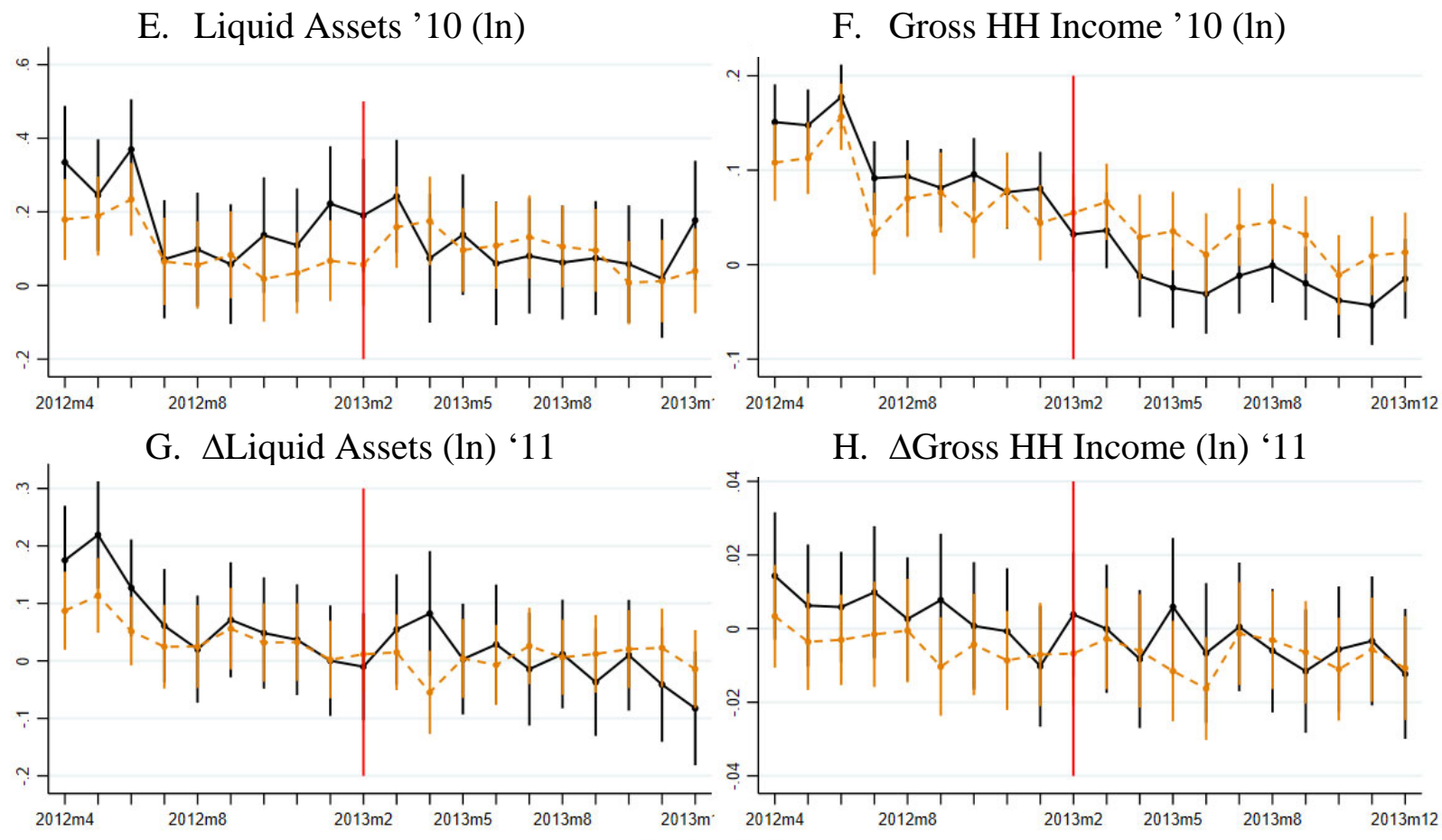

H. $\Delta$ Gross HH Income (ln) ' 11

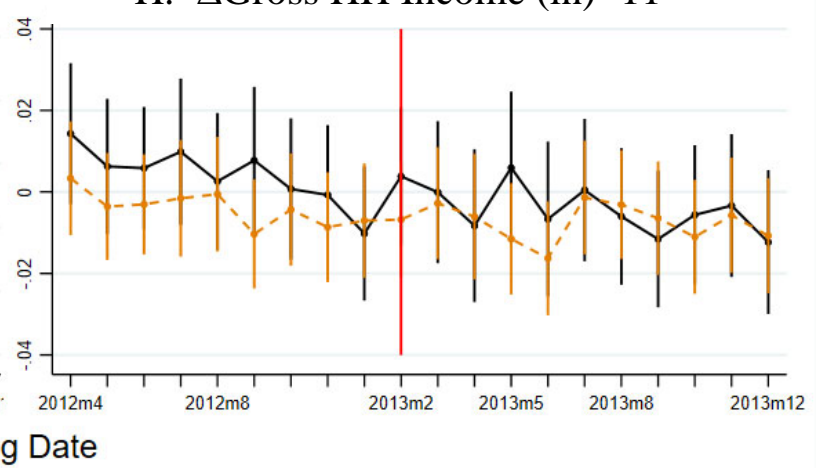

$\longrightarrow$ FTHBs

Non-FTHBs 


\section{Figure A8. Probability of Homeownership by Dec-2016:}

\section{All Households w/ Life-Events 2012-2013}

This figure shows that there is no observable effect of life-events on the probability of ever owning a house during our sample period. We look at all households with a life-event between 2012 and 2013 who do not who a home at the end of 2011. We do not require them to become a first-time homebuyer during this period. Of the households in this sample, 16.9\% own a home at the end of 2016. We regress a dummy variable equal to 1 if they own any real estate by the end of 2016 on the month of the life-event. Life-events are defined to be months with changes in the number of members of a household (ex. birth of a child). The vertical lines show 95\% confidence intervals which are based on heteroskedasticity robust standard errors clustered at the household level

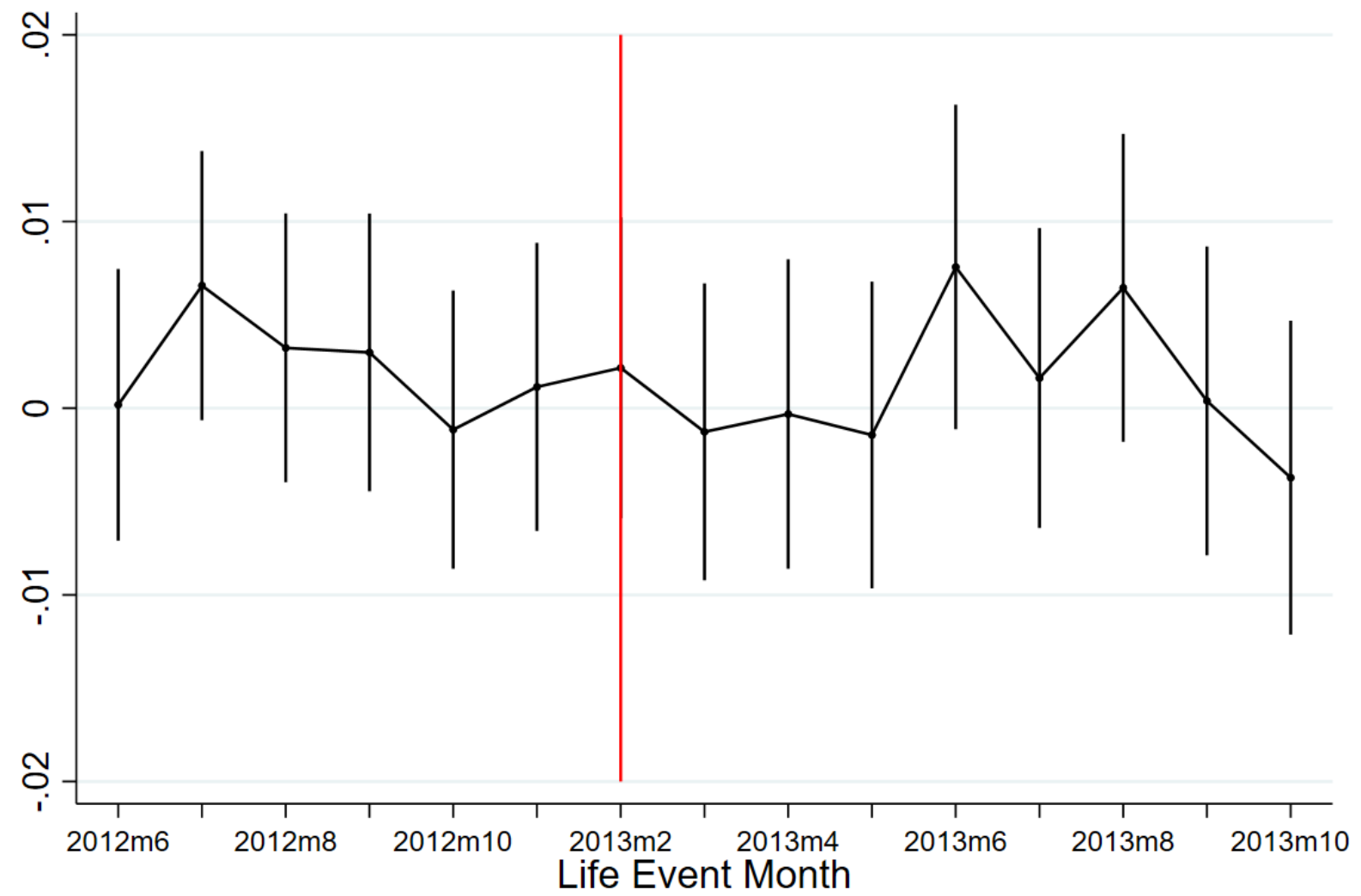




\section{Figure A9. All Other Buyers by Previous Housing Tenure Length}

This figure looks at the effects of the 2013 reform on all other buyers (non-FTHBs) with shorter previous housing spells ( $<10$ yrs - solid black lines) vs. those that were longer ( $>=10$ yrs - dashed yellow lines). There are no sharp jumps in any of the relevant variables around that date, neither in absolute terms or relative to each other. We use the full set of all non-FTHBs buying a house between April 2012 and December 2013. In panel $\mathrm{A}$, we regress the \% of the observed mortgage balance reduction, not including any amortization through linked accounts, from January to December 2015 on categorical dummy variables for each cohort (month of closing on the house), where February 2013 is the omitted month. No other control variables are included. Panels B-D are the same as Panel A, but have different dependent variables: (B) the initial home purchase price in thousands of euros, (C) the change in the natural log of liquid assets over 2015, and (D) the change in liquid assets over 2015 divided by the mortgage balance at the end of 2014 (D). Each dot is the estimate for the relative effect each month, with 95\% confidence intervals plotted for each point. The x-axis includes the cohort (month of closing). Confidence intervals are based on heteroskedasticity robust standard errors clustered at the household level.

A. Observed \% Mtg Bal Reduction '15

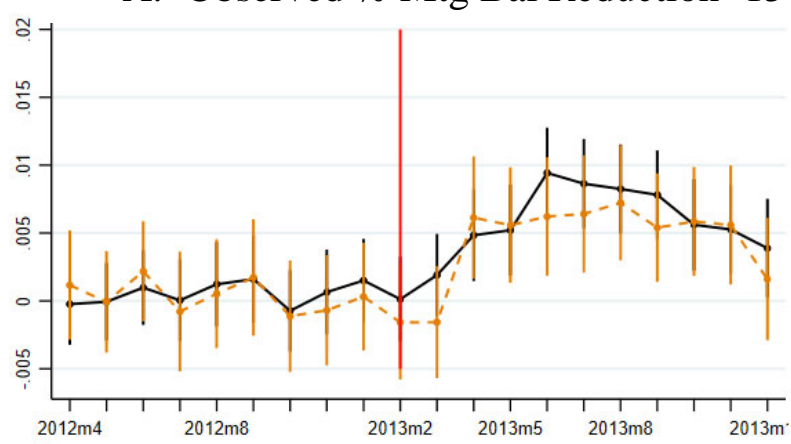

C. $\Delta$ Liquid Assets (ln) ' 15
B. Home Purchase Price (€000s)

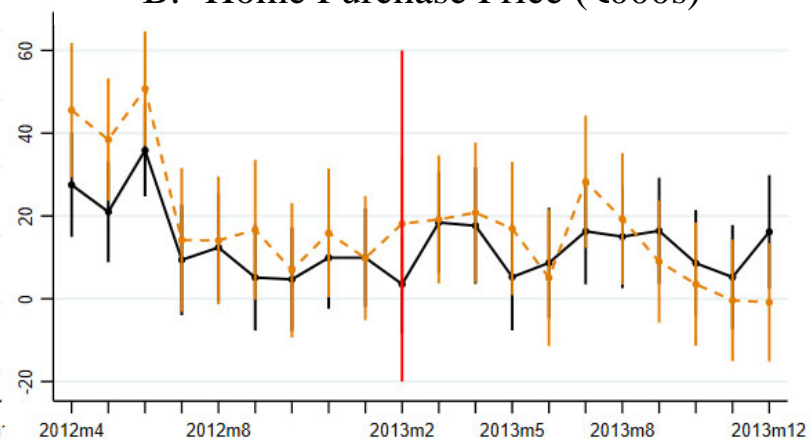

D. $\Delta$ Liquid Assets ‘'15/Mtg Bal '15
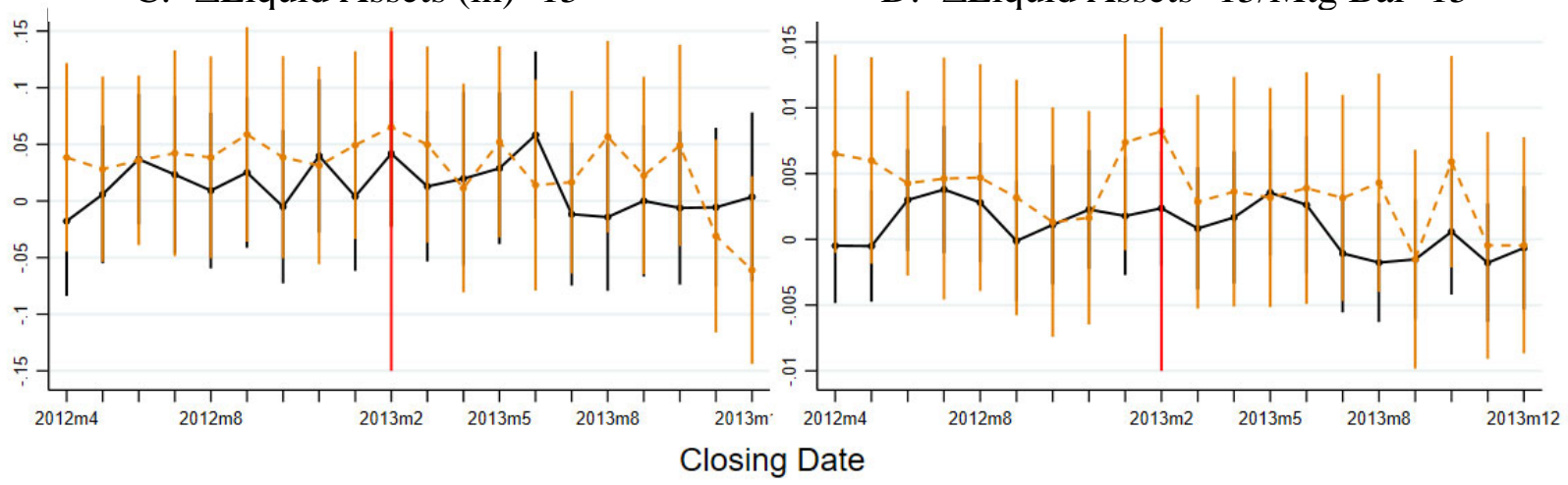

Closing Date 


\section{Figure A10. Dutch vs. U.S. Homeowners by Age}

Panel A depicts the percentage of household heads who report having real estate by five-year age group categories between 20 and 65 . Panel B reports the percent of homeowners that are "hand-to-mouth" - those without significant levels of liquidity $(<\$ 10$ USD/€7K) who have an outstanding mortgage balance remaining - for the same age groups as in Panel A. Data on U.S. households (solid black line) comes from the 2016 Survey of Consumer Finances, while data for Dutch households (dotted gray line) comes from CBS as of 2012.

\section{Panel A. Homeownership Rate}

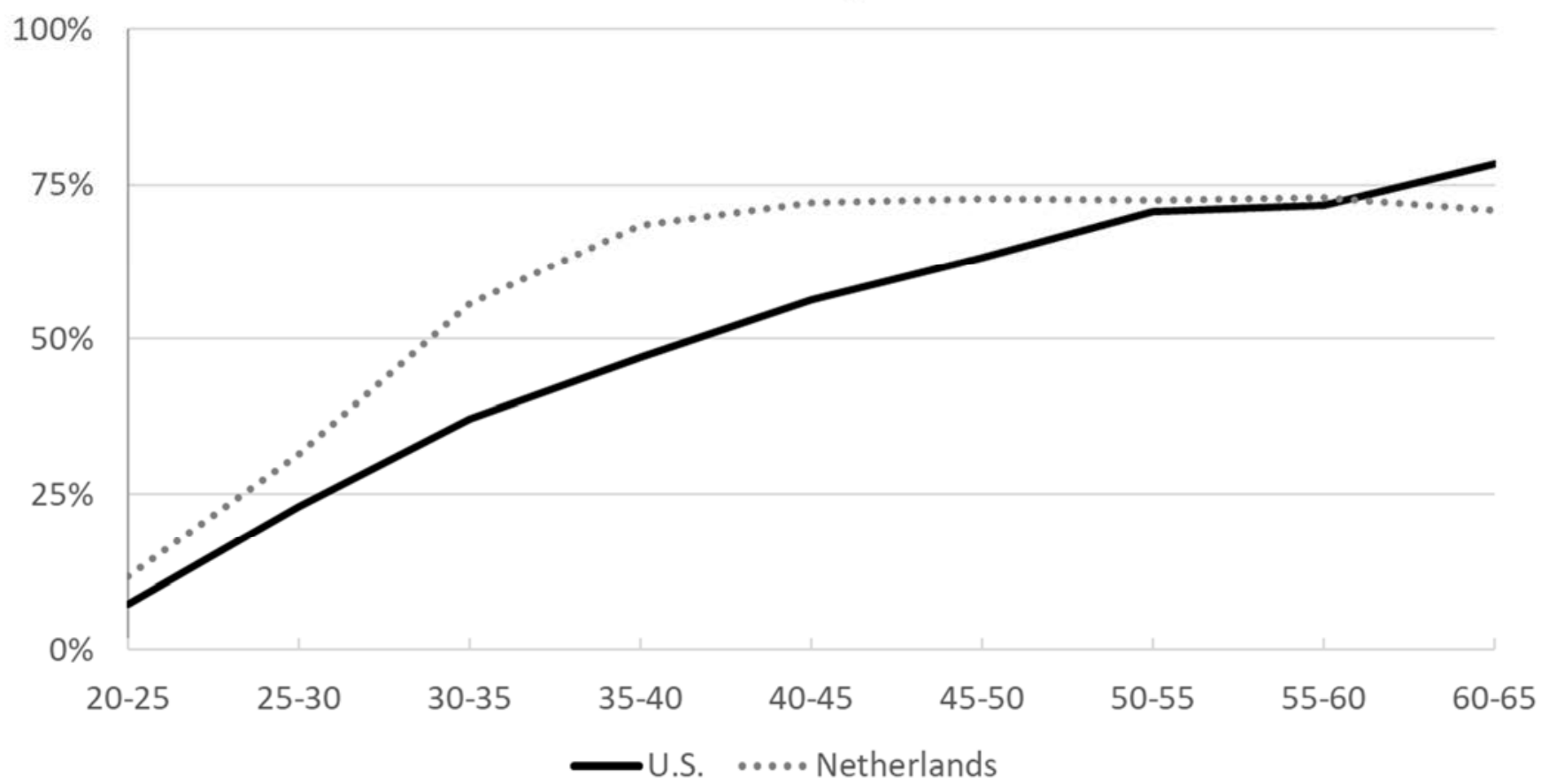

Panel B. Percentage of Homeowners w/ an Outstanding Mortgage Balance Remaining

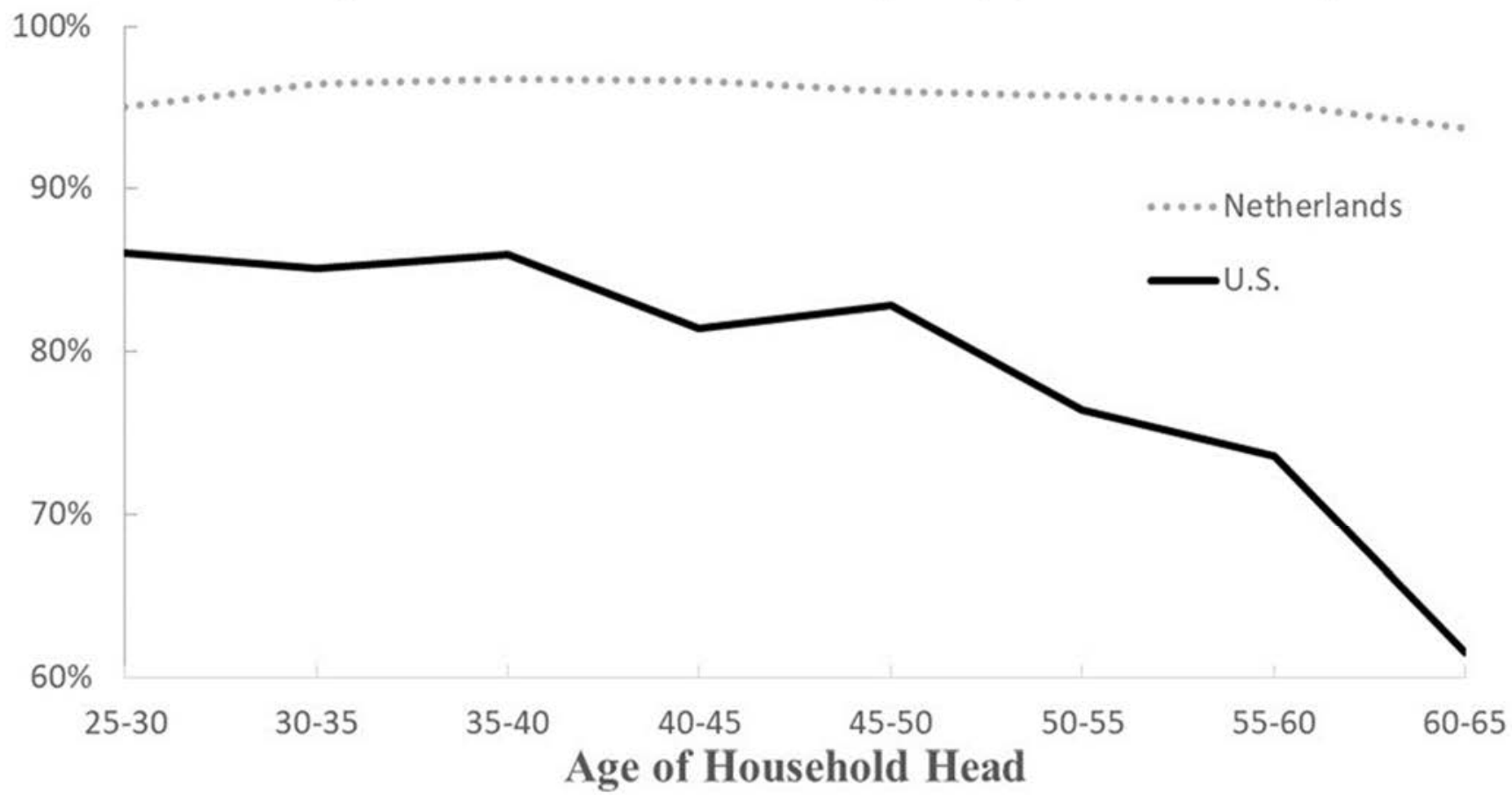




\section{Table A1. Robustness: Alternative Wealth Measures}

This table shows that the effect of mortgage amortization on wealth accumulation is robust to the specific measure of wealth used. Columns 1-5 replicate the two-stage least squares regression in Table 2, Column 3, but use different wealth measures to construct the dependent variable. Column 1 uses an alternative for voluntary pension contributions. In particular, it includes all pension contributions no matter their size and drops any instances of missing values (as opposed to setting them to 0 as is done in the main specification). Column 2 includes the appraised value of real estate in the measure of wealth. Column 3 combines Columns 1 and 2. Column 4 looks at the levels (rather than changes) of household net worth (all assets - liabilities) and home equity, both as of December 2015. Column 5 also looks at the levels of household net worth and home equity and replicates the specification from Table 4, Column 8, using life-events as instrument. T-statistics (and 95\% confidence intervals) with heteroskedasticity robust standard errors clustered at the household level are shown in parentheses (brackets). ${ }^{* * *},{ }^{* *}$, and ${ }^{*}$ indicate statistical significance and the $1 \%, 5 \%$ and $10 \%$ level, respectively.

\begin{tabular}{lccccc}
\hline & IV & IV & IV & IV & IV \\
& $(1)$ & $(2)$ & $(3)$ & $(4)$ & (5) \\
& $\Delta$ Wealth & $\Delta$ Wealth & $\Delta$ Wealth & $\begin{array}{c}\text { Net Worth } \\
\text { '15 }\end{array}$ & $\begin{array}{c}\text { Net Worth } \\
\text { '15 }\end{array}$ \\
& '15 & '15 & \\
\hline MTG Repaid '15 & $0.921^{* * *}$ & $1.232^{* * *}$ & $1.167^{* * *}$ & & \\
& {$[0.78,1.06]$} & {$[0.98,1.49]$} & {$[0.90,1.43]$} & & \\
& $(13.18)$ & $(9.47)$ & $(8.57)$ & & \\
& & & & & \\
Home Equity '15 & & & & $0.970^{* * *}$ & $0.983^{* * *}$ \\
& & & & {$[0.88,1.06]$} & {$[0.62,1.35]$} \\
& & & & $(21.85)$ & $(5.26)$ \\
\hline Pension Alt. Measure & $\mathrm{Y}$ & - & $\mathrm{Y}$ & - & - \\
Include Real Estate & - & $\mathrm{Y}$ & $\mathrm{Y}$ & $\mathrm{Y}$ & $\mathrm{Y}$ \\
IV & Post(buy) & Post(buy) & Post(buy) & Post(buy) & Post(life) \\
F-Stat & 378.0 & 369.3 & 378.0 & 472.5 & 27.0 \\
Obs & 41,559 & 42,468 & 41,559 & 42,468 & 16,581 \\
Adj. ${ }^{2}$ & 0.316 & 0.126 & 0.119 & 0.663 & 0.656 \\
\hline
\end{tabular}




\section{Table A2. Robustness: Alternative Samples}

This table shows that the effect of mortgage amortization on wealth accumulation is robust to the sample used. All columns replicate the two-stage least squares regression from Table 2, Column 3, but include larger samples. Columns 1 includes all wealth changes (not just those $<€ 100 \mathrm{k}$ as in the main analysis of the paper). Column 2 includes all mortgage changes (not just those where the year-over-year \% change is $<30 \%$ as in the main analysis of the paper). Column 3 includes all households and observations regardless of size and previous home-owner status as long as they purchase a home during the period of interest. This means including all the observations in Columns 1 and 2 , and non-first-time homebuyers. Tstatistics (and 95\% confidence intervals) with heteroskedasticity robust standard errors clustered at the household level are shown in parentheses (brackets). $* * *, * *$, and * indicate statistical significance and the $1 \%, 5 \%$ and $10 \%$ level, respectively.

\begin{tabular}{lccc}
\hline & IV & IV & IV \\
& $(1)$ & $(2)$ & $(3)$ \\
& $\Delta$ Wealth & $\Delta$ Wealth & $\Delta$ Wealth \\
& '15 & '15 & '15 \\
\hline MTG Repaid '15 & $1.013^{* * *}$ & $0.976^{* * *}$ & $1.000^{* * *}$ \\
& {$[0.87,1.12]$} & {$[0.85,1.12]$} & {$[0.92,1.08]$} \\
& $(13.65)$ & $(14.82)$ & $(24.49)$ \\
\hline Include large wealth $\Delta \mathrm{s}$ & $\mathrm{Y}$ & - & $\mathrm{Y}$ \\
Include large mtg \% $\Delta \mathrm{s}$ & - & $\mathrm{Y}$ & $\mathrm{Y}$ \\
Include all & - & - & $\mathrm{Y}$ \\
IV & Post(buy) & Post(buy) & Post(buy) \\
F-Stat & 229.9 & 143.3 & 35.1 \\
Obs & 42,666 & 44,555 & 113,231 \\
Adj. $\mathrm{R}^{2}$ & 0.418 & 0.615 & 0.944 \\
\hline
\end{tabular}




\section{Table A3. Robustness: Alternative Amortization Assumptions}

This table shows that the effect of mortgage amortization on wealth accumulation is robust to the amortization assumptions used for linked savings accounts. All columns replicate the two-stage least squares regression in Table 2, Column 3, but make different assumptions to impute the unobserved amortization through linked savings accounts for mortgages contracted before the reform. Column 1 simply uses the raw data (no adjustment). Columns 2-5 assume that pre-reform mortgages have a larger or smaller amortizing component than the $50 \%$ we assume in the main analysis: 30\%, 40\%, 60\%, and 70\%, respectively. Column 6 and 7 assume an interest rate on pre-reform mortgages and their linked savings accounts that is higher or lower than the $4.5 \%$ we assume in the main text: 6.0 and 3.0\%, respectively (this matters for the speed of amortization). T-statistics (and 95\% confidence intervals) with heteroskedasticity robust standard errors clustered at the household level are shown in parentheses (brackets). $* * *, * *$, and * indicate statistical significance and the $1 \%, 5 \%$ and $10 \%$ level, respectively.

\begin{tabular}{|c|c|c|c|c|c|c|c|}
\hline & $\begin{array}{c}\text { IV } \\
(1) \\
\Delta \text { Wealth } \\
\text { '15 }\end{array}$ & $\begin{array}{c}\text { IV } \\
(2) \\
\Delta \text { Wealth } \\
\text { '15 }\end{array}$ & $\begin{array}{c}\text { IV } \\
\text { (3) } \\
\Delta \text { Wealth } \\
\text { '15 }\end{array}$ & $\begin{array}{c}\text { IV } \\
\text { (4) } \\
\Delta \text { Wealth } \\
\text { '15 }\end{array}$ & $\begin{array}{c}\text { IV } \\
\text { (5) } \\
\Delta \text { Wealth } \\
\text { '15 }\end{array}$ & $\begin{array}{c}\text { IV } \\
(6) \\
\Delta \text { Wealth } \\
\text { '15 }\end{array}$ & $\begin{array}{c}\text { IV } \\
(7) \\
\Delta \text { Wealth } \\
\text { '15 }\end{array}$ \\
\hline MTG Repaid '15 & $\begin{array}{c}0.996^{* * *} \\
{[0.92,1.07]} \\
(27.03)\end{array}$ & $\begin{array}{c}0.994^{* * *} \\
{[0.90,1.09]} \\
(21.37)\end{array}$ & $\begin{array}{c}0.994^{* * *} \\
{[0.90,1.09]} \\
(19.49)\end{array}$ & $\begin{array}{c}0.993^{* * *} \\
{[0.87,1.12]} \\
(15.74)\end{array}$ & $\begin{array}{c}0.993^{* * *} \\
{[0.85,1.13]} \\
(13.88)\end{array}$ & $\begin{array}{c}0.994^{* * *} \\
{[0.90,1.10]} \\
(19.62)\end{array}$ & $\begin{array}{c}0.994^{* * *} \\
{[0.90,1.09]} \\
(15.25)\end{array}$ \\
\hline $\begin{array}{l}\text { \% of pre-reform mortgage that is } \\
\text { amortizing - assumed }\end{array}$ & 0 & $30 \%$ & $40 \%$ & $60 \%$ & $70 \%$ & $50 \%$ & $50 \%$ \\
\hline interest rate - assumed & N/A & $4.5 \%$ & $4.5 \%$ & $4.5 \%$ & $4.5 \%$ & $6.0 \%$ & $3.0 \%$ \\
\hline IV & Post(buy) & Post(buy) & Post(buy) & Post(buy) & Post(buy) & Post(buy) & Post(buy) \\
\hline F-Stat & 853.4 & 541.4 & 451.5 & 294.9 & 228.6 & 457.6 & 276.3 \\
\hline Obs & 42,468 & 42,468 & 42,468 & 42,468 & 42,468 & 42,468 & 42,468 \\
\hline Adj. $\mathrm{R}^{2}$ & 0.342 & 0.333 & 0.333 & 0.330 & 0.331 & 0.332 & 0.330 \\
\hline
\end{tabular}




\section{Table A4. Robustness: Standard Errors}

This table shows that the effect of mortgage amortization on wealth accumulation is robust to the specific method of computing standard errors. All columns replicate the two-stage least squares regression in Table 2, Column 3, but make different assumptions about the error structure - in the main analysis we cluster at the household-level. Column 1 computes heteroskedasticity robust standard errors without any clustering. Columns 3 and 4 cluster at the level of four digit postal code (PC4) or municipality (gemeente), respectively. Column 4 collapses the data at the level of the household head and clusters standard errors at the municipality level. ***, **, and * indicate statistical significance and the $1 \%, 5 \%$ and $10 \%$ level, respectively.

\begin{tabular}{lcccc}
\hline & IV & IV & IV & IV \\
& $(1)$ & $(2)$ & $(3)$ & $(4)$ \\
& $\Delta$ Wealth & $\Delta$ Wealth & $\Delta$ Wealth & $\Delta$ Wealth \\
& $' 15$ & $' 15$ & $' 15$ & $' 15$ \\
\hline MTG Repaid '15 & $0.993^{* * *}$ & $0.993^{* * *}$ & $0.993^{* * *}$ & $0.978^{* * *}$ \\
& {$[0.92,1.07]$} & {$[0.89,1.11]$} & {$[0.88,1.11]$} & {$[0.87,1.09]$} \\
& $(25.97)$ & $(17.29)$ & $(17.26)$ & $(18.00)$ \\
\hline Standard Error Clustering & None (robust) & PC4 & Muni & Muni \\
Collapse & - & - & - & HH-level \\
IV & Post(buy) & Post(buy) & Post(buy) & Post(buy) \\
F-Stat & 847.7 & 336.3 & 322.3 & 458.1 \\
Obs & 42,468 & 42,468 & 42,468 & 25,248 \\
Adj. $\mathrm{R}^{2}$ & 0.331 & 0.331 & 0.331 & 0.321 \\
\hline
\end{tabular}




\section{Table A5. Labor Supply: \# of HH Earners}

This table shows that the number of earners within a household increase in order to pay for the increase in wealth accumulation caused by the additional mortgage amortization. The sample includes all first-time home buyers who closed on their home between October 2012 and September 2013. Column 1 looks at the change in the number of household members who are reported to work at least an average of 10 hours per week over a given year from 2012 to 2015 for a given household. We regress this on Post, a dummy variable equal to 1 if a household closed on their house after May $1^{\text {st }}$, 2013. The control group are all buyers who closed on their homes from October 2012 to February 2013 , while the treated are those who closed from May to September 2013. The reform applied to the timing of going under contract, not closing, which typically takes at least two months. It is uncertain whether those who closed in March and April went under contract before or after January $1^{\text {st }}$. We therefore exclude them. Column 2 restricts the sample to the subset of households with at least two working age people living in the household as of 2012 . Column 3 uses the same sample as Column 2, but looks at the change in a dummy variable equal to 1 if there is only a single earner in the household. Column 4 is the same as column 3, but restricts the sample to households who either experience a change from single to multiple earners or the reverse. Tstatistics with heteroskedasticity robust standard errors clustered at the household level are shown in parentheses. ***, **, and * indicate statistical significance and the $1 \%, 5 \%$ and $10 \%$ level, respectively.

\begin{tabular}{lcccc}
\hline & OLS & OLS & OLS & OLS \\
& $(1)$ & $(2)$ & $(3)$ & $(4)$ \\
& $\Delta \# H H$ & $\Delta \# H H$ & $\Delta$ Single & $\Delta$ Single \\
& Earners & Earners & Earner HH & Earner HH \\
& '15-'12 & '15-'12 & '15-'12 & '15-'12 \\
\hline Post & $0.0239^{* * *}$ & $0.0299^{* * *}$ & $-0.0223^{* * *}$ & $-0.146^{* * *}$ \\
& $(3.36)$ & $(2.65)$ & $(-2.60)$ & $(-2.65)$ \\
\hline$>1$ Working Age in HH & - & $\mathrm{Y}$ & $\mathrm{Y}$ & $\mathrm{Y}$ \\
Chg in \#Single Earner & - & - & - & $\mathrm{Y}$ \\
F-Stat & - & 369.3 & 141.6 & 141.6 \\
Obs & 42,468 & 24,424 & 24,424 & 3,805 \\
$\mathrm{R}^{2}$ & 0.001 & 0.001 & 0.001 & 0.005 \\
Mean '12 Dep Var & 1.38 & 1.69 & 0.27 & 0.48 \\
\hline
\end{tabular}




\section{Table A6. Labor Supply: Hours Worked}

This table shows that households increase the number of hours worked to pay for the increase in wealth accumulation caused by the rise in mortgage amortization. The rise in hours worked explains all of the observed future rise in household gross income. Column 1 regresses 2012 household gross income for first-time homebuyers in our main sample on their total household hours worked in 2012. Column 2 has the same specification as Column 1, but looks at changes in gross household income and household hours worked from 2012 to 2015. Columns 3 and 4 use the change in total household hours worked (either in level or in logs) as dependent variable and regress this on Post, a dummy variable equal to 1 if a household closed on their house after May $1^{\text {st }}$, 2013. Column 5 replicates the estimates from Table 3, Column 1, but includes a control for the change in total household hours worked from 2012 to 2015 - this explains virtually all of the income increase. T-statistics with heteroskedasticity robust standard errors clustered at the household level are shown in parentheses. ${ }^{* * *},{ }^{* *}$, and $*$ indicate statistical significance and the $1 \%, 5 \%$ and $10 \%$ level, respectively.

\begin{tabular}{|c|c|c|c|c|c|}
\hline & $\begin{array}{c}\text { OLS } \\
(1) \\
\text { Income } \\
\text { '12 } \\
\end{array}$ & $\begin{array}{c}\text { OLS } \\
(2) \\
\Delta \text { Income } \\
\text { '15-'12 } \\
\end{array}$ & $\begin{array}{c}\text { OLS } \\
\text { (3) } \\
\Delta \text { Hrs Worked } \\
\text { '15-'12 }\end{array}$ & $\begin{array}{c}\text { OLS } \\
\text { (4) } \\
\Delta \text { Hrs Worked } \\
\text { '15-'12 (ln) }\end{array}$ & $\begin{array}{c}\text { OLS } \\
(5) \\
\Delta \text { Income } \\
\text { '15-'12 } \\
\end{array}$ \\
\hline Post & & & $\begin{array}{c}86.12^{* * *} \\
(8.35)\end{array}$ & $\begin{array}{c}0.0492^{* * *} \\
(3.22)\end{array}$ & $\begin{array}{l}364.2 \\
(1.59)\end{array}$ \\
\hline $\begin{array}{l}\Delta \text { Hrs Worked } \\
\text { '15-'12 }\end{array}$ & & $\begin{array}{l}10.54^{* * *} \\
(40.79)\end{array}$ & & & $\begin{array}{l}10.52^{* * *} \\
(40.62)\end{array}$ \\
\hline Hrs Worked '12 & $\begin{array}{l}15.64^{* * *} \\
(74.63)\end{array}$ & & & & \\
\hline Obs & 42,468 & 42,468 & 42,468 & 42,468 & 42,468 \\
\hline $\mathrm{R}^{2}$ & 0.310 & 0.175 & 0.004 & 0.000 & 0.175 \\
\hline
\end{tabular}




\section{Table A7. Four-Year Cumulative Effects}

This table shows that the 2013 reform's effect on mortgage amortization and wealth accumulation is persistent over the full length of our sample period. The sample includes all first-time home buyers who closed on their home between October 2012 and July 2013. The reform applied to the timing of going under contract, not closing, which typically takes at least two months. It is uncertain whether those who closed in March and April went under contract before or after January $1^{\text {st }}$. We therefore exclude them. As with all analyses that examine savings in 2014, we exclude buyers near the end of 2013, since they will have just purchased a home, making them less comparable to those buying closer to the reform in the beginning of 2013. The table looks at outcomes over the four years from December 2013 till December 2017. Column 1 reports estimates from a two-stage least square regression using variation in the timing of the closing of home purchase for first-time home buyers around the 2013 reform as instrument. The endogenous variable of interest is the amount of the mortgage balance that is repaid over that four-year period and the instrumental variable, Post, is a dummy variable equal to 1 if a household closed on their home after May $1^{\text {st }}, 2013$. The control group are all buyers who closed on their homes from October 2012 to February 2013, while the treated are those who closed from May to July 2013. The dependent variable is the change in wealth from the end of December 2013 till December 2017. Column 2 shows the first stage of the two-stage least squares analysis from Column 1. Column 3 is the same as Column 2, but the dependent variable is the amount of the mortgage balance that is repaid over that four-year period divided by the amount of all liquid assets as of December 2017. Some households have a low level of liquid assets in 2017 and, because the dependent variable in Column 3 is a ratio, this creates an outlier problem. We therefore exclude households with less than €100 in liquid assets and those with a ratio greater than 50 . T-statistics with heteroskedasticity robust standard errors clustered at the household level are shown in parentheses. $* * *, * *$, and $*$ indicate statistical significance and the $1 \%, 5 \%$ and $10 \%$ level, respectively.

\begin{tabular}{lccc}
\hline & IV & OLS & OLS \\
& $(1)$ & $(2)$ & $(3)$ \\
& $\begin{array}{c}\text { WWealth } \\
\text { '13-'17 }\end{array}$ & $\begin{array}{c}\text { MTG Repaid } \\
\text { '13-'17 }\end{array}$ & $\begin{array}{c}\text { MTG Repaid '13-'17/ } \\
\text { Liquid Assets '17 }\end{array}$ \\
\hline MTG Repaid & $0.887^{* * *}$ & & \\
'13-'17 & {$[0.73,1.05]$} & & \\
& $(10.81)$ & & \\
Post & & & \\
& & $8139.6^{* * *}$ & $1.205^{* * *}$ \\
& & $(23.91)$ & $(11.10)$ \\
\hline Control Group & $10 / 12-2 / 13$ & $10 / 12-2 / 13$ & $10 / 12-2 / 13$ \\
Treated Group & $5 / 13-7 / 13$ & $5 / 13-7 / 13$ & $5 / 13-7 / 13$ \\
IV & Post & - & - \\
F-Stat & 508.8 & - & - \\
Obs & 25,169 & 25,169 & 25,169 \\
Adj. $\mathrm{R}^{2}$ & 0.176 & 0.053 & 0.012 \\
\hline
\end{tabular}




\section{Table A8. Resellers Sample}

This table shows that effects for households selling and buying a new home ("resellers") are similar for the sample as a whole - resellers do not appear to extract large quantities of home equity. The table examines the sub-sample who bought their first home between 2012 and 2013 and then resold it by December of 2016. The focus is on whether resellers who bought after the 2013 reform take the opportunity of a later move to extract any additional home equity accumulated due to the extra amortization. Column 1 regresses the December 2017 mortgage balance on Post, a dummy variable equal to 1 if they closed on their house after May $1^{\text {st }}$, 2013. The control group are all buyers who closed on their homes from October 2012 to February 2013, while the treated are those who closed from May to September 2013. The reform applied to the timing of going under contract, not closing, which typically takes at least two months. It is uncertain whether those who closed in March and April went under contract before or after January $1^{\text {st }}$. We therefore exclude them. Columns 2-5 have the same specification as Column 1, but use different dependent variables: the mortgage balance and the stock of liquid assets (deposits + stocks + bonds), either in levels or as the natural logarithm, all as of December 2017, or the amount of home equity extracted at the time of sale (change in home equity between the times of sales and purchase). Column 6 is the same as the two-stage least squares specification in Table 5, Column 2, but the instrument and the endogenous variable include an interaction with a dummy variable equal to 1 if the household resold their home by the end of 2016. T-statistics with heteroskedasticity robust standard errors clustered at the household level are shown in parentheses. ${ }^{* *}, * *$, and * indicate statistical significance and the $1 \%, 5 \%$ and $10 \%$ level, respectively.

\begin{tabular}{|c|c|c|c|c|c|c|}
\hline & $\begin{array}{c}\text { OLS } \\
(1) \\
\text { MTG Bal } \\
\text { '17 }\end{array}$ & $\begin{array}{c}\text { OLS } \\
(2) \\
\text { MTG Bal } \\
\text { '17 (ln) }\end{array}$ & $\begin{array}{c}\text { OLS } \\
\text { (3) } \\
\text { Home Equity } \\
\text { Extraction at Sale }\end{array}$ & $\begin{array}{c}\text { OLS } \\
\text { (4) } \\
\text { Liquid Assets } \\
\text { '17 }\end{array}$ & $\begin{array}{c}\text { OLS } \\
\text { (5) } \\
\text { Liquid Assets } \\
\text { '17 (ln) }\end{array}$ & $\begin{array}{c}\text { IV } \\
(6) \\
\Delta \text { Wealth } \\
\text { '16 }\end{array}$ \\
\hline Post & $\begin{array}{c}-15,507.0^{* *} \\
(-2.04)\end{array}$ & $\begin{array}{c}-0.0629^{* *} \\
(-2.00)\end{array}$ & $\begin{array}{c}-1,303.0 \\
(-0.25)\end{array}$ & $\begin{array}{c}-1,056.9 \\
(-0.40)\end{array}$ & $\begin{array}{c}-0.0702 \\
(-0.58)\end{array}$ & \\
\hline MTG Repaid '16 & & & & & & $\begin{array}{c}1.214^{* * *} \\
{[0.84,1.59]} \\
(6.34)\end{array}$ \\
\hline $\begin{array}{l}\text { MTG Repaid '16 } \\
\text { x Reseller Sample }\end{array}$ & & & & & & $\begin{array}{l}-0.149 \\
(-1.25)\end{array}$ \\
\hline Resellers '13-'16 & $\mathrm{Y}$ & $\mathrm{Y}$ & $\mathrm{Y}$ & $\mathrm{Y}$ & $\mathrm{Y}$ & - \\
\hline IV & - & - & - & - & - & Post \\
\hline F-Stat & - & - & - & - & - & 261.9 \\
\hline Obs & 1,768 & 1,768 & 1,768 & 1,768 & 1,768 & 38,741 \\
\hline Adj. $R^{2}$ & 0.0029 & 0.0032 & 0.0001 & -0.0003 & -0.0003 & 0.290 \\
\hline
\end{tabular}

